\title{
根未完成永久雬の根管中間位歯髄切断後の根尖 閉鎖に関する光顕的ならびに電顕的研究
}

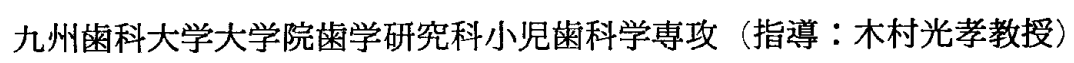

$$
\text { 高橋 成 久 }
$$

昭和63年12月22日受付

\section{A Light and Electron Microscope Study of Apical Closure after Pulpotomy at the Mid-Root-Canal of Immature Teeth \\ Shigehisa Takahashi \\ Department of Pedodontics (Director: Prof. Mitsutaka Kimura) Kyushu Dental College, Kitakyushu, Japan}

Pulpotomy at the middle portion of the root canal was performed on immature teeth of young adult dogs. Healing process of the pulpal wounds, change in nerve fibers in the dental pulp, process of the formation of the dentin barrier, and apical closure including growth of the root were investigated under the light and the electron microscope.

The results were as follows:

1. Three days after operation, a necrotic layer was formed extensively directly under the pulpotomied surface, and the nerve fibers in the inflammatory layer directly under the necrotic layer were degenerated. Observation under thc transmission electron microscope (TEM) of this region showed undifferentiated mesenchymal cells poor in cell organellae and nerve fibers with marked destruction of myelin of the myelin sheath. At the root apex, Hertwig's epithelial sheath was observed.

2. A week after operation, a calcified barrier was beginning to be formed on the pulpotomied surface and slight inflammatory cellular infiltration limited to the dental pulp directly under the surface was seen. Directly under the barrier, cells which were comparatively large in cell and nucleus sizes were found. The TEM observation of these cells showed cells which had nuclei with small depressions in part, were rich in rough-surfaced endoplasmic reticula, and showed wide intercellular space.

3. At the second week after operation, the formation of the dentin barrier was beginning to be seen directly under the pulpotomied surface. Observation of this region, viewed from the pulpal side, under the scanning electron microscope (SEM) showed large and small calcospherite-like structures fused together and piled. The TEM observation of the cells at this region showed large oval nuclei with gently sloped depressions, and many rough-surfaced endoplasmic reticula and mitochondria in cytoplasm around the nucleus, and odontoblast-like cells connected by junctional complex. The TEM observation of the nerve fibers showed normal nerve fibers of laminated structure with orderly formed myelin sheath.

At the root apex from this time, addition of connecting cellular cementum was seen 
and the TEM observation showed active cementoblasts in both the control and experimental groups.

4. The cases from one to two months after operation showed the formation of the dentin barrier with dentinal tubules, on the pulpotomied surface, continuously from the periphery to the center of the pulp. The SEM observation of this region showed peritubular dentin on the coronal side, but its borders with matrix were distinct at some places and indistinct at other places. Dentinal tubules were not uniform. The TEM observation of the cells directly under the barrier showed, as in the case of odontoblasts of root dentin, large ovoid nuclei poor in chromatin, and uneven distribution of cell organellae such as mitochondria and many rough-surfaced endoplasmic reticula. As to the nerve fibers in the dental pulp, small nerve bundles and single nerve fibers were ascending toward the dentin barrier. Active apposition of cellular cementum was seen at the root apex and the TEM observation of this region showed cells with a large oval nucleus and rich in rough-surfaced endoplasmic reticula and mitochondria.

5. Six months after operation, the dentin barrier was thickened. The SEM observation of the dentin barrier showed that, on the pulpal side, calcospherites were orderly distributed, fused and increased in compactness, and had uniform dentinal tubules. The nerve fibers, at this time, reached near the dentin barrier with some running parrarel with the dentin barrier and terminating in the odontoblast layer and some infiltrating into the barrier together pulpal intrinsic tissue and blood vessels.

At the root apex, slight internal resorption of dentin was observed in part and the formation of cementum with inclusion of cementocytes was seen in those sites. Calcification was completed and about the same degree of apical closure was seen as in the control group. The SEM observation of this region showed the formation a flat surface and highly calcified cementum lacunae. The TEM observation of cementoblasts on the surface of cementum showed resting cells poor in rough-surfaced endoplasmic reticula and mitochondria. Fibrous bundles of the periodontal membrane were arranged functionally.

\section{Key words: Immature teeth/Mid-root-canal pulpotomy/Apical closure/}

\section{Light and Electron microscope}

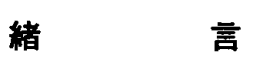

日常の小児歯科臨床において, 漓蝕罹患率は激減して いるとはいえ，根未完成永久苗は食物残渣の停滞を起と

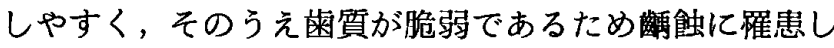
やすい傾向にある．また外傷などにより歯髄処置を必要 とする症例に遭遇する機会は非常に多い，根未完成永 久雨の歯髄処置法としては歯髄の障害の程度に応じて Apexogenesis と Apexification の 2 通りあることは 周知のとおりである. 本教室においては根未完成霜の歯 㔠道処置に関して一連の研究を行っており，A pexogene-

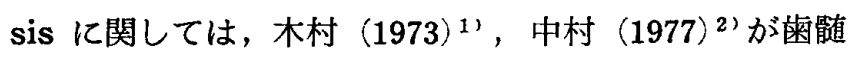
処置を完全に施し覆髄唷が適切ならば雨根の発育，根尖 閉鎖は未処置歯と同様に行われることを実証した。また 神内 $(1985)^{32}$, 中村 $(1987)^{4}$ は粜髄処置後の菊骮道内神 経線維の動態について神経組織学的に検索を行い詳細に わたって報告している．とのような流れのなかで臨床 の場において，炎症が根部歯骾に波及している症例で は Apexification を期待しなければならない。鬼塚 $(1986)^{5}$ '，長谷川 $(1986)^{6)}$ らの報告にもあるように， Apexification は㐘根の発育は望めず，有細胞セメント 質による根尖閉鎖も未好置菌に比べ非常に困難である . 
そてで根部歯暘の一部に炎症が波及した場合でも出来る 限り柬戫を保存することにより, 歯根の発育と根尖閉鎖 を期待し，柬牙の保存に努めるため根管中間位歯髄切断 による Apexogenesis が望まれる。しかし根末完成永 久荬の根管中間位雪䯑道切断後の創傷治癒, 神経線維の動 態, 歯根の発育および根尖閉鎖に関する研究はほとんど みられない，そこで著者は根未完成永久䨓の根管中間位 䨑髄切断後の根尖閉鎖に関して, 光顕的ならびに電䫓的 に検索を行い，いささかの知見を得たので報告する.

\section{実験材料ならびに実耠方法}

\section{I . 実験材料}

実験 動物は生後 6〜 7 カ月の雑種 健康幼若犬を 用い た. 生後 5 力月前後上り飼育を開始し環境に十分適俯さ せたのち実験に供した．実験歯は下顎左側第 2 ，第 3 ， 第 4 小曰雪で反対側同名歯は何ら処置を施さず対照群と して用いた。また，実験歯の歯根形成状態を出来る限り 一定に保つため，下頟第 2 ，第 3 乳臼歯の自然脱落後 10 日目を基準として実験を行った．実験に用いた幼若犬は 12頭で実験期間と例数は Table 1 亿示しているとおり である，実験に用いた覆蕃剤は水酸化カルシウム製剤を 使用した。

\section{I . 実験方法}

実験動物は，Sodium pentobarbital（商品名：somnopentyl)により体重 $1 \mathrm{~kg}$ 当たり $25 \mathrm{mg}$ の割合で静 脈内注射を施し, 全身麻酔下に雪科用 X線撮影を行い, 歯根形成状態を確認した，次に口腔内を $3 \% \mathrm{H}_{2} \mathrm{O}_{2}$ で， 実験部位を Iodoglycerin で清掃消毒した，その後簡易 防湿下にて滅菌水の持続的注水下にカーボランダムポイ ントで歯冠部歯䓄を霜肉縁上 $1 \mathrm{~mm}$ の高さまで均等に削 除した. 次に滅菌ラウンドバー（No. 2〜5）で雪粕腔 の開㧨を行った．根管中間位歯髄切断に際して，X線写 真を参考にし霜根の $\frac{1}{2}$ の部位を目安とし, 根管の太さと ほぽ同じ烕菌ロングネックラウンドバーにストッパーを つけ，その長さまで咸菌水の持続的注水下で根部菌㖪を 切断した. 次に $3 \% \mathrm{H}_{2} \mathrm{O}_{2}$ と $8 \% \mathrm{NaOCl}$ 溶液で交互洗 浄を行い，最後に0.9\%の滅菌生理的食塩水で洗浄後， 滅菌綿栓を切断面に軽く圧接して止血し, 根管内を十分
乾燥させた，前迈の覆酭剤による覆罩を行い，酸化覀鉛 ユージノールセメントにて裏層し，インバーテッドコー ンバー（No. 34，35) でアンダーカットを付与し，アマ ルガム充填を施し，手術を終了した．手術終了後们霜科 用X線フィルムを用いて, 再度実験部位の撮影を行っ た。

\section{II . 観察方法}

術後 3 日， 1 週間， 2 週間， 1 力月， 2 力月， 6 力月 経過後，下顎骨を採取した後に直ちに実験部位と対照雨 のX線撮影を行い，神経染色固定液に浸漬した。固定後 $50 \%$ 蟻酸と $20 \%$ クエン酸ナトリウムの等量混合液で脱灰 し, エタノール系列脱水後, 通法に従いパラフィン包埋

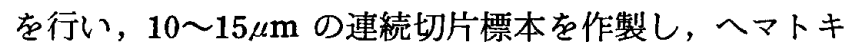
シリン・エオシン重染色，渡辺鍍銀染色ならびに Ungewitter $(1951)^{7}$ ) の尿素硝酸銀法の Powers $\left.(1952)^{8}\right)^{8}$ 変 法をさらに改良した神経染色を施し，鏡見した。

走查電顕的観察は下䫈骨採取後直ちに10\%中性ホルマ リンにて固定後，ダィヤモンドディスクならびに簡易切 断機（T. Morita Corporation 社製）を用いて，注水 下で第 4 小曰米の遠心側と第 2 小曰雪の近心側を綐断 し，次にX線写真を参考にして，各歯牙を歯根分岐部及

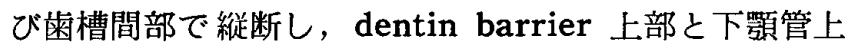
部で横断し，単一塊とした。その後再度 $\mathrm{X}$ 線撮影を行 い，X線写真を参考に dentin barrier と根尖部を含ん だ各小塊とした後， $8 \% \mathrm{NaOCl}$ 溶液で軟組織を除去し 超音波洗净を施した。標本は霜軸方向に縦断し，50\%正 リン酸にて 1 分間酸処理を施し，エタノール系列にて脱 水し, 酶酸イソアミル置換後, 臨界点乾燥を行い, イオ ンスパッタ（日本電子 JFC-100）にて Au coating を 施し，JSM-25 及び JSM-T 300 走査型電子顕微鏡で観 察した。

次に透過型電顕的観察は，下颚骨を採取時に被検菌周 用で切断し， $4{ }^{\circ} \mathrm{C}$ のカコジル酸バッファーで洗浄後, $1 \%$ パラホルムアルデヒドー $3 \%$ ルタタールアルデヒド 固定液に $4{ }^{\circ} \mathrm{C}$ で12時間固定した。同固定液注水下にて ダイヤモンドディスクを用いて dentin barrier，根尖 部ならびに歯周組織を含む小塊に横断した。ささらに同固 定液中に 1 週間浸漬固定後, $2.5 \%$ グルタールアルデヒ

Table 1 Experimental period and number of case

\begin{tabular}{c|c|c|c|c|c|c|c}
\hline Duration & 3rd day & 1st week & 2nd week & 1st month & 2nd month & 6th month & Total \\
\hline $\begin{array}{l}\text { Control group } \\
\text { Experimental }\end{array}$ & 12 & 12 & 12 & 12 & 8 & 8 & 64 \\
\hline \begin{tabular}{l} 
group \\
\hline
\end{tabular}
\end{tabular}


ド液による $7.5 \%$ EDTA 溶液で 2 〜 週間脱灰し, 力 コシル酸バッファーで洗浄後, $2 \%$ オミウム酸にて後 固定を行った。エタノール系列にて脱水し, プロピレン オキサイド置換後, Epon 812 にて包埋した。試料はガ ラスナイフを用いて LKB-4800 型超乏クロトームにて $2 \sim 3 \mu \mathrm{m}$ の準超薄切片を調製し，0.1\%トルイジンブ ルー染色を施して, 観察部位を光顕的に確認した. 脱脂 ナイフでトリミングした後, ダイヤモンドナイフ（Diatome 社製) を拼用し，0.1 $\mathrm{m}$ 以下の超薄切片を作製 し, Reynolds 氏法による酢酸ウラニル・クエン酸鉛重 染色を施し，JEM-100C透過型電子顕微鏡で観察した。

\section{実 験 成 䋶}

\section{I ・一般組織所見ならびに神経組織所見}

術後 3 日

歯髄切断面直下には薬剤の残存がみられ，薬剤に接し て広範囲に壊死層の形成が認められる，壊死層内には大 小の石灰塊が散在している，細胞成分は融解しており， 全体的に希薄となっている. 壊死層内の血管は赤血球で 満たされているのが認められる，壊死風と生活曾髄との 境界部には大小不同, 凹凸不整の石灰塊が辺縁部から歯 髄中央部に連続して諗められ，いわゆるリン酸カルシウ ムの連続した von Kóssa 陽性顆粒層に相当する分界層 の出現が認められる. 分界層直下ならびにやや下方の歯 䯣内には血管の拡張, 充血ならびに限局した出血巣や, 好中球を中心とする炎症性細胞浸潤が認められる，その 周囲に線維芽細胞の出現が著明に認められ, 出血㮺をと り囲んでいる（Fig. 1)，さらに下方の根尖に至るまで の柬髄は充血調であるほかは, 正常像を呈している．根 尖相当部は広く開大し, 根管中間位付近とほぼ同様な幅 を有していて blunderbuss の状態を呈している.また

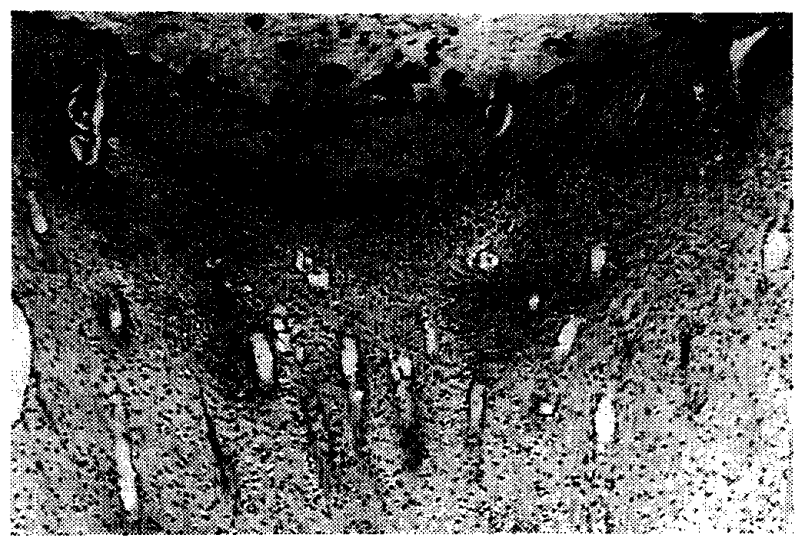

Fig. 1 On the 3rd day $\mathrm{H} \cdot \mathrm{E}$ stain. $\times 50$
Hertwig 上皮鞘は著明に俧められる（Fig．2）。

神経線維についてみると，切断面の壊死凮内には膨 化, 自己融解寸前の変性神経線維がみられ, 直下の歯䯣 内を横断像でみると Fig. 3 に示しているように変性 した軸索の集合が明瞭である。

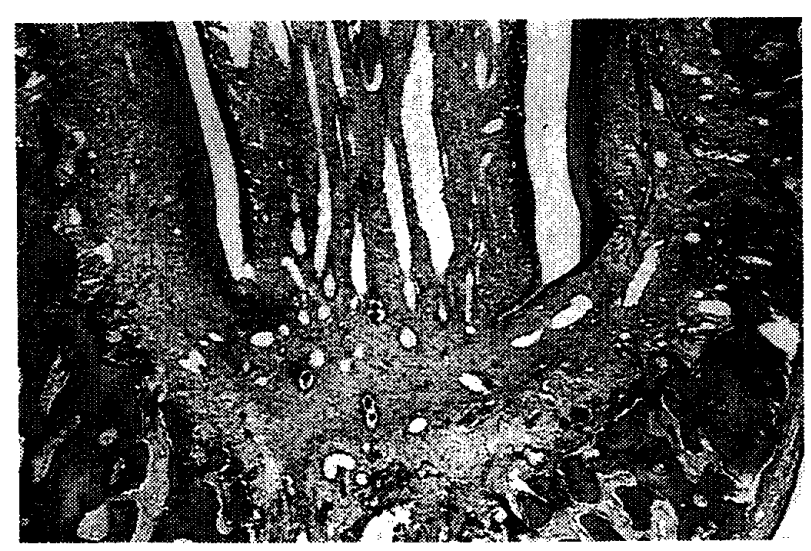

Fig. 2 On the 3rd day H. E stain. $\times 20$

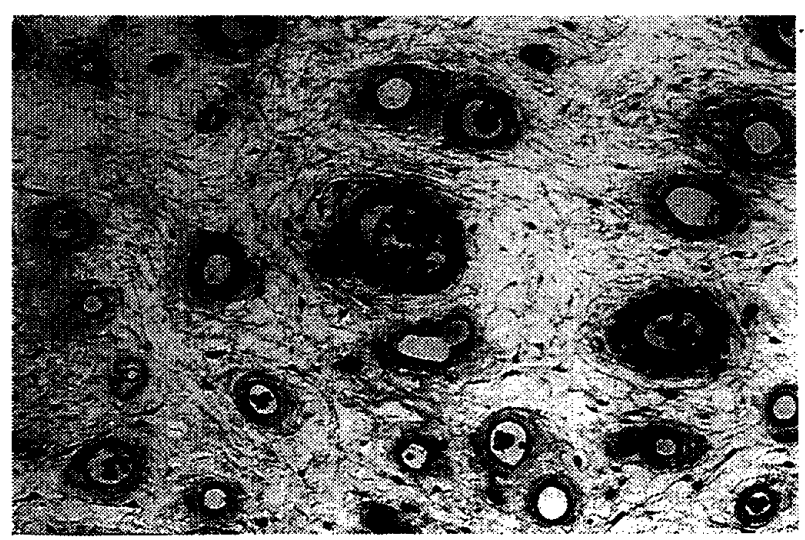

Fig. 3 On the 3rd day

Toluidine blue stain. $\times 100$

術後 1 週間

柬幗切断面直下には, 術後 3 日経過例と同様に薬剤の 残存がみられ，その下には広範囲に壊死層の形成が認め られる，壊死層内の細胞成分は融解しており，さらに希 薄となっている．リン酸カルシウムの連続した分界層直 下にはエオジンに好染した有機質の形成所見が諗めら れ，比較的核と細胞体の大型な細胞が出現している辺縁 部においては石灰化柵形成開始所見も認められる，有機 質形成直下の歯髄およびゃや下方の柬髄内には好中球を 主体とする軽度の炎症性細胞浸潤が認められるが，限局 している (Fig. 4). 切断面を鍍銀染色で観察すると大 型細胞の間を柬髄より膠原線維が活発に進入している. 
根尖相当部は未だ広く開大し，Hertwig 上皮鞘が著 明に認められ，有細胞セメント質の形成は認められない (Fig． 5 )。根尖部を鍍銀染色で観察すると，Hertwig 上皮鞘の先端部在中心とする同心円状に膠原線維が束状 になって根尖蒾根膜側から上皮隔膜を通過し，根部菌㖪 に進入し，歯冠部に向って上行している.

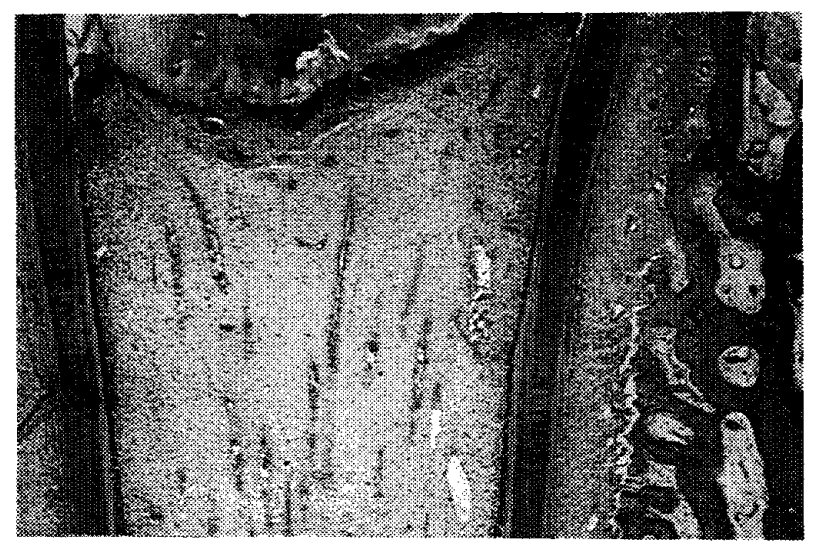

Fig. 4 On the 1st week

$\mathrm{H} \cdot \mathrm{E}$ stain. $\times 20$

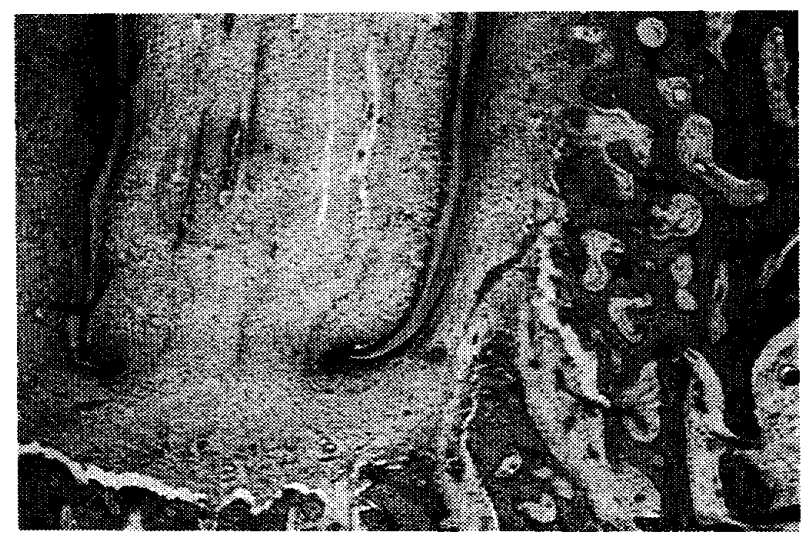

Fig. 5 On the 1st week

$\mathrm{H} \cdot \mathrm{E}$ stain. $\quad \times 20$

神経線維についてみると，切断面直下には変性所見が みられるものの, やや離れた苗髄内には神経線維の変性 をみることはない，芷噵内中央部を Schwann 細胞を 伴った微細な再生神経線維が活発に切断面に向って上行 している (Fig．6)，下顎管内の下歯槽神経より分岐し， 管外に出た神経のうち菌鮪内に分布するものは根尖相当 部直下の霜根膜及び槽間中隔，根管中隔側の Hertwig 上皮鞘の外側歯根膜に集合し，複雑に分岐，吻合して神 経叢を形成している. 神経叢の中には一部屈曲, 蛇行し た神経線維も認められる（Fig．7）。

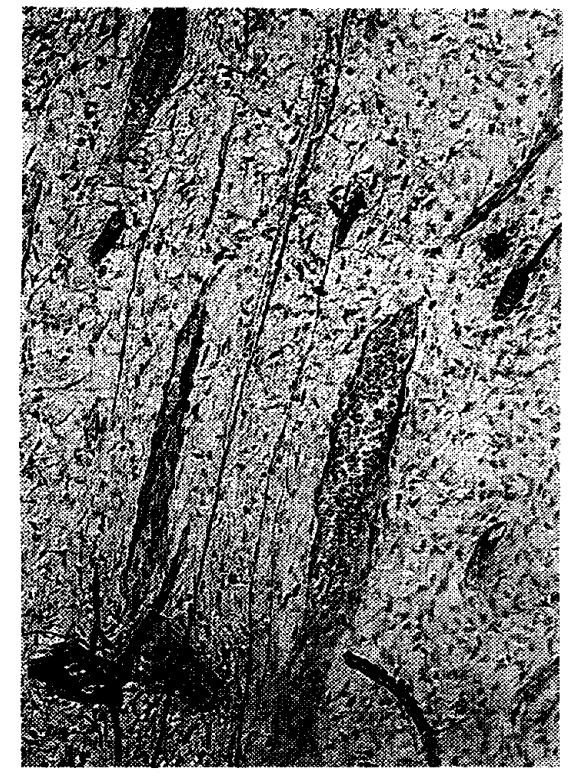

Fig. 6 On the 1st week

Stain for nerve fibers. $\times 100$

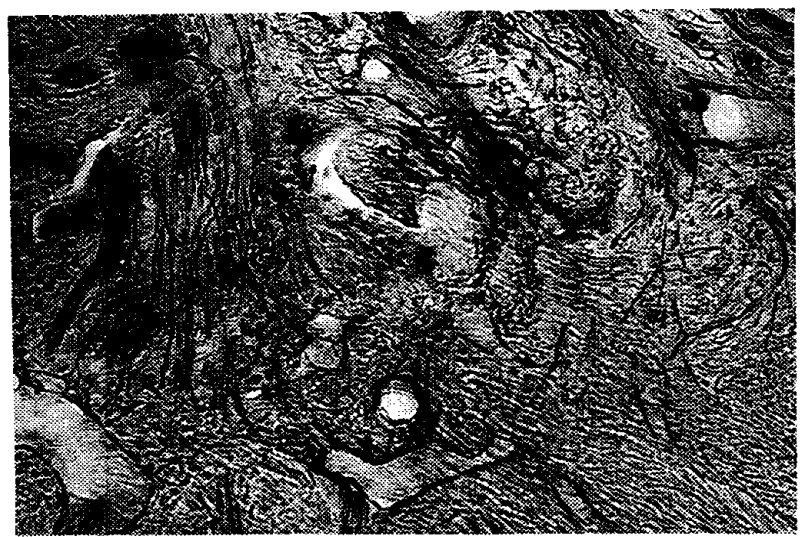

Fig. 7 On the 1st week

Stain for nerve fibers. $\times 100$

\section{術後 2 週間}

歯喠切断面直下には辺縁部から菌艏中央部に連続して 細胞を含有した dentin barrier の形成開始所見がみら れ，柵最内方の辺縁部の一部にはエオシンに好染した幼 若象牙質の形成が誌められ，柵形成部直下の㐘髄には， 大型の核を含む長方形または立方形の細胞の出現が認め られる，画髄には軽度の充血が認められるが，炎症性細 胞浸潤はほとんど喼められない（Fig．8）。

歯根象牙質は雬筙切断部から根尖相当部に連続してへ マトキシリン不染首が認められ，その内側には象牙質が 添加されている．その内側にはエオジンに好染する幼若 象牙質が一定の幅を保ち，根尖部まで連続している．そ れに伴って象牙牙細胞層が重層をなして整然と配列して 


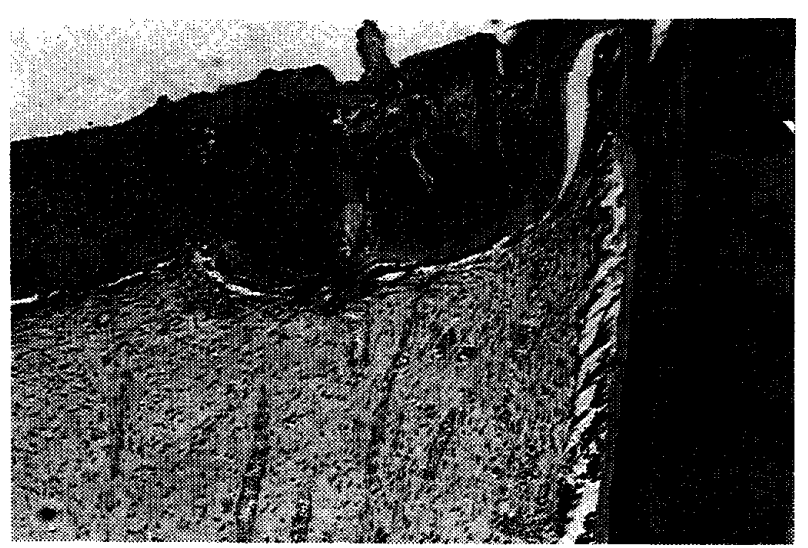

Fig. 8 On the 2nd week

$\mathrm{H} \cdot \mathrm{E}$ stain. $\times 50$

いる. 根尖相当部は Hertwig 上皮鞘が消失し, 有細胞 セメント質の添加が始まり根尖中央部に向って伸長して いるものもみられるが，根尖部はいまだ開大し，歯䯙と 米根膜は大きく交通している（Fig.9）.

神経線維についてみると, 術後 1 週間目とほほ同様の 所見を呈し, 霜髄内には単一神経線維, 微細な神経線維 が切断面に向って上行しており, 神経束はほとんどみら れない。

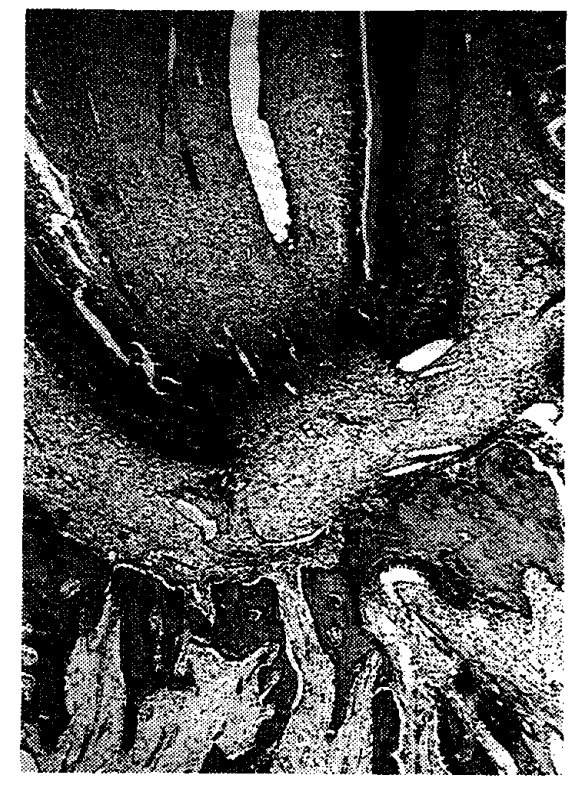

Fig. 9 On the 2nd week

$H \cdot$ E stain. $\quad \times 20$

術後 1 力月

菌髄切断面は辺縁部から㐘髄中央部に連続して dentin barrier の形成が羿められる場合と Fig. 10 に示 すように切断面は歯髄の固有組織と血管の進入により不
完全である場合がある.また dentin barrierと骨様象 牙質の組織瘁合が認められる，柬髄は根尖部に至るまで 正常像を呈している . 根尖部は有細胞セメント質の添加 により閉鎖が進行の途上にあり，側枝様構造も明瞭に認 められる．根尖部セメント質の表層部にはセメント芽細 胞が活発に増殖している . 一部にはセメント芽細胞を含 有しながらセメント質の石灭化が進行している所見も認 められる (Fig. 11). この時期の米根膜線維を鍍銀染色 で観察するとセメント質から歯槽骨に向から歯根膜線維 束が認められるが，いまだ不規則である（Fig. 12）。

神経線維についてみると下方の柬髄内より上行する小 神経束および単一神経線維は，そのまま上方の dentin barrier に向けて上行するものも認められるが，象牙武 紐胞層にまで至るものはほとんどない，また柵に向かう 神経線維は㨁前で向きを変えて辺縁に向けて伸長するも のも認められ，それらの大部分の神経線維は正常像を保 っている（Fig. 13，14）. 根尖相当部直下の雬根膜に集 合する神経線維は複雑に分岐，吻合して神経丵を形成す

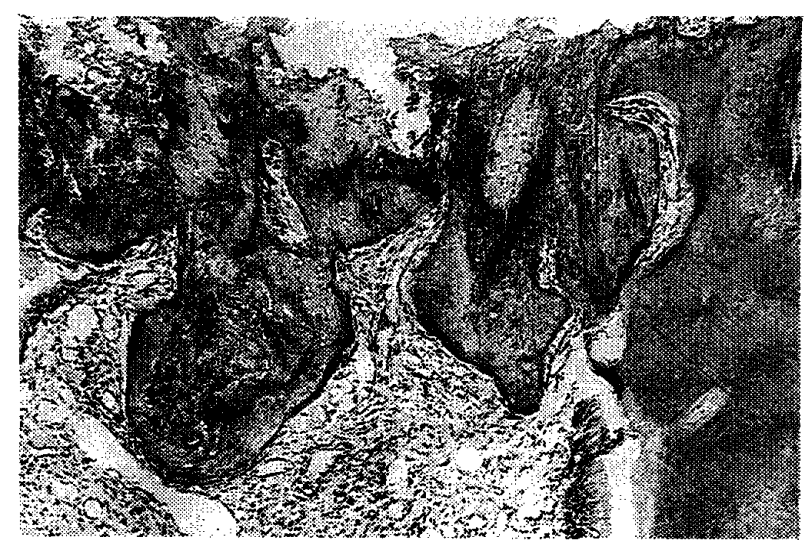

Fig. 10 On the 1st month H. E stain. $\times 50$

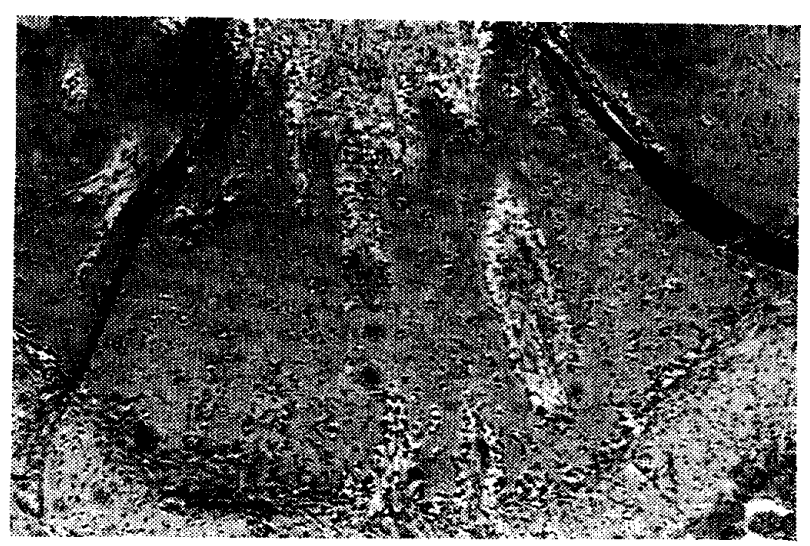

Fig. 11 On the 1st month $\mathrm{H} \cdot \mathrm{E}$ stain. $\times 50$ 


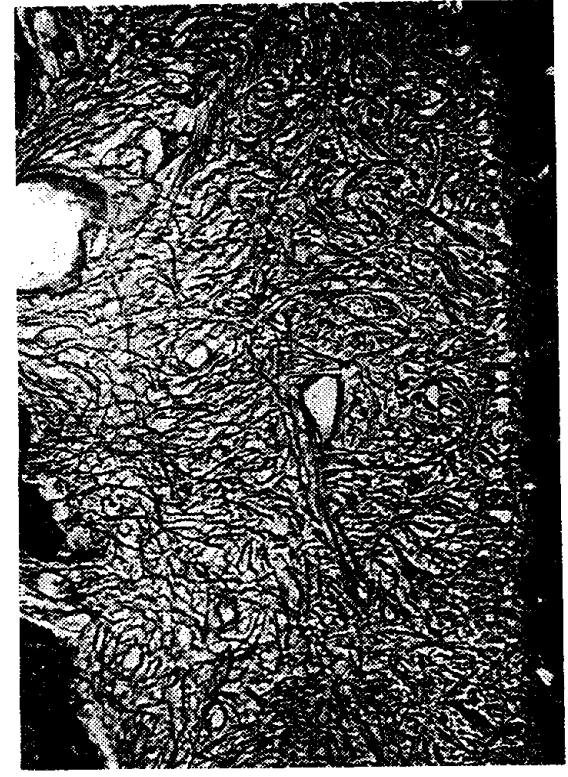

Fig. 12 On the 1st month

Silver stain. $\times 100$

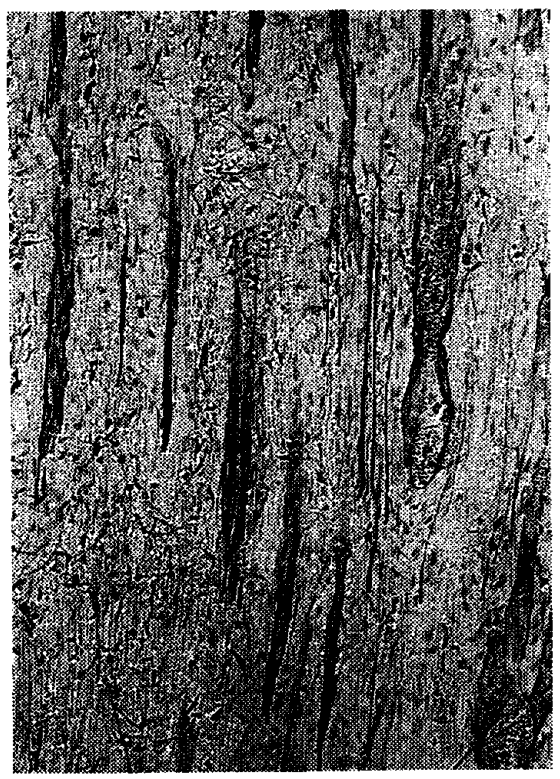

Fig. 13 On the 1st month

Stain for nerve fibers. $\times 100$

るが，根尖から苗髄内に進入する直前で変性に陥入る神 経線維も散見される。

術後 2 力月

歯髄切断面面下の壊死層は大部分剝離消失している. 残存する壊死層には大小の石灰塊がわずかに琹められ る.壊死層に接して，辺縁部から粜髄中央部に連続して 象牙細管構造をもった dentin barrier の形成がみられ る、柵最内方にはエオシンに好染した幼若象牙質がほほ 一定の幅を保って珰められ，歯根象牙質と連続してい

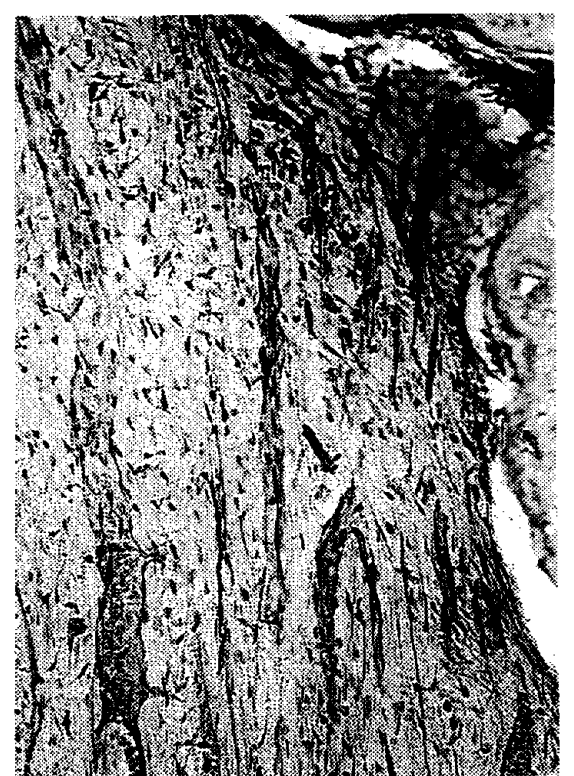

Fig. 14 On the 1st month

Stain for nerve fibers. $\times 100$

る。それに伴って象牙芽細胞が規則正しく配列している (Fig. 15) 、歯根象牙質は歯髄切断部汃ら根尖相当部に かけて厚径を増している. dentin barrier 直下の㐘髄 は根尖部に至るまで正常像を呈している。根尖部は一般 には有細胞セメント質の添加が進行し, 分岐根管の形成 が認められる（Fig. 16）。この時期では対照雪について も歯根の発育はほぼ同程度の所見を呈している。

神経線維についてみると，歯䯣内中央部を走行する神

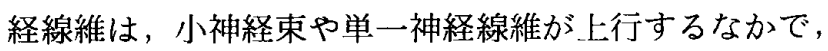

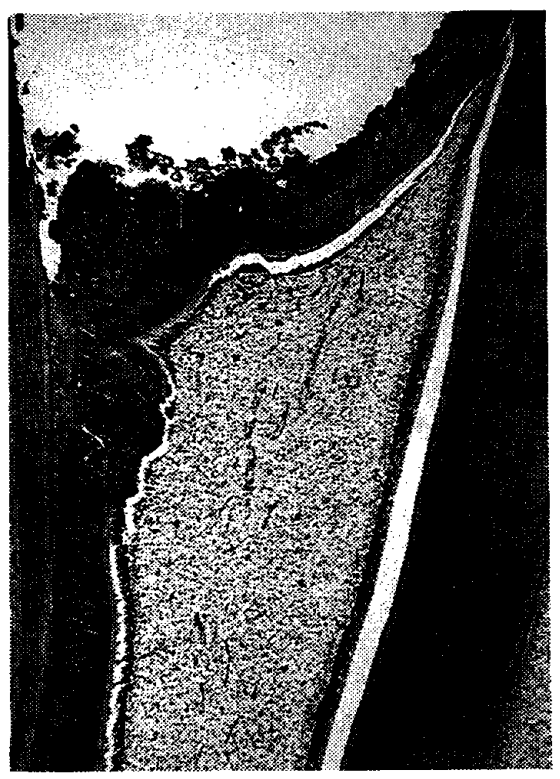

Fig. 15 On the 2nd month

$\mathrm{H} \cdot \mathrm{E}$ stain. $\times 20$ 


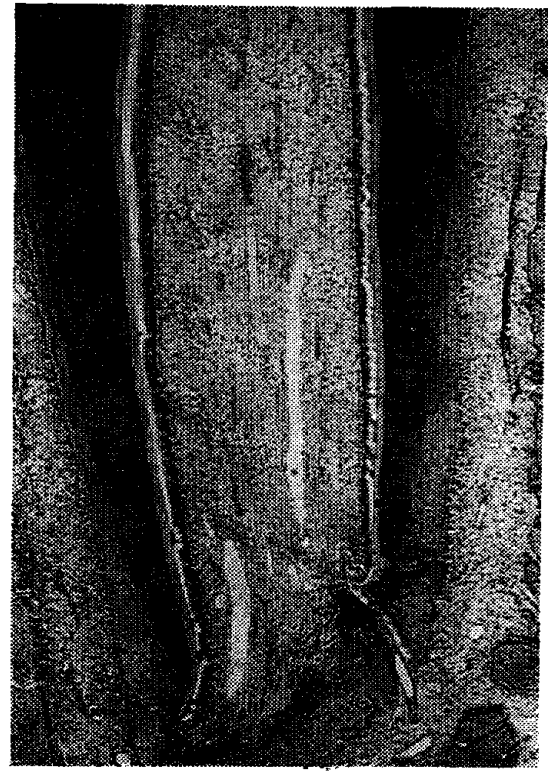

Fig. 16 On the 2nd month

$\mathrm{H} \cdot \mathrm{E}$ stain. $\times 20$

蒾根の象牙芽細胞層に向かう交叉，吻合する微細な神経 線維として散見される（Fig. 17）。また，根尖部にセメ ント細胞を封入したセメント小腔が認められるようにな ると，神経叢より分岐し分岥根管を通じて血管とともに 主に小神経束が歯䯣内に進入するようになる(Fig. 18).

術後 6 力月

歯髄切断面直下の壊死層は一層を残し，大部分剝離 消失している，ての時期では壊死風に接して dentin barrier の形成がみられる場合と Fig. 19 に示すように

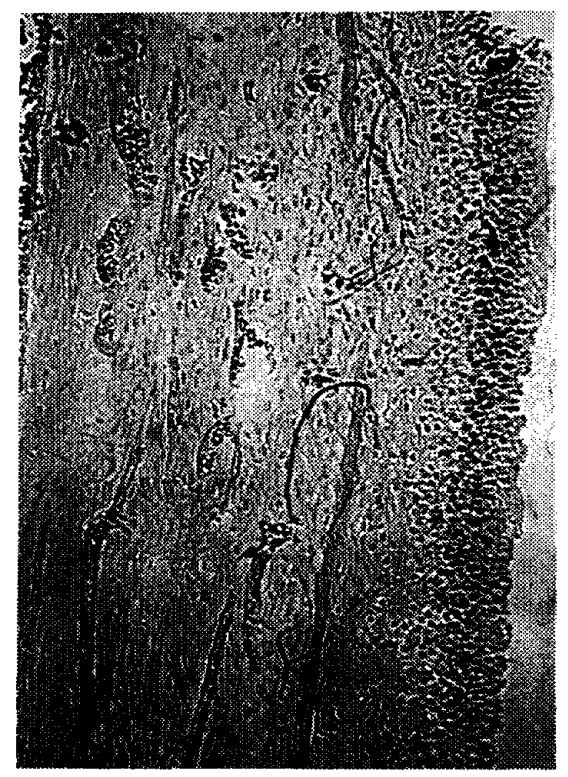

Fig. 17 On the 2nd month

Stain for nerve fibers. $\times 100$

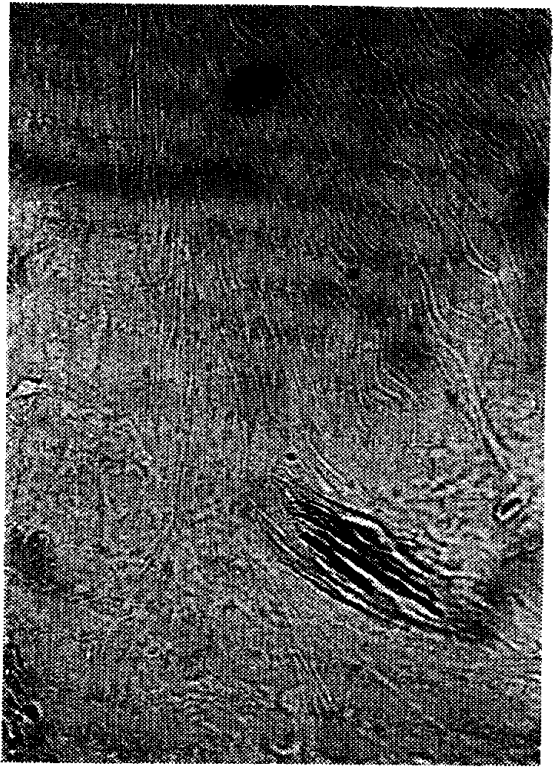

F!g. 18 On the 2nd month

Stain for nerve fibers. $\times 100$

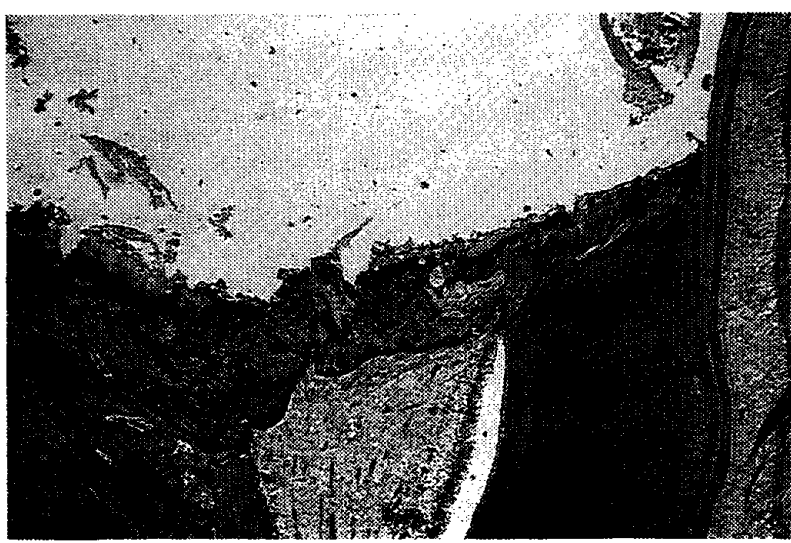

Fig. 19 On the 6 th month $\mathrm{H} \cdot \mathrm{E}$ stain. $\times 20$

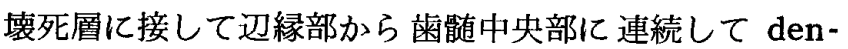
tin barrier 々骨様象牙質の癒合所見がみられ，一部を 除いて象牙細管構造をもっている. dentin barrier は 厚径を増している. dentin barrier と曾根象牙質は組 織㾤合が行われ，歯鹃は被覆保護され正常像を保ってい る. dentin barrier を鍍銀染色で観察すると，表風は 粗い線維性基質を呈し, 内層は象牙細管構造をもった dentin barrier が厚く形成され，歯髄からは好銀線維 が活発に蛇行しながら幼若象牙質に進入している（Fig． 20).

根尖部では一部にわずかな象牙質の内部吸収が みら れ，その部にはセメント細胞を封入したセメント質の形 成がみられる.また，根尖部象牙質の外側は有細胞セメ 


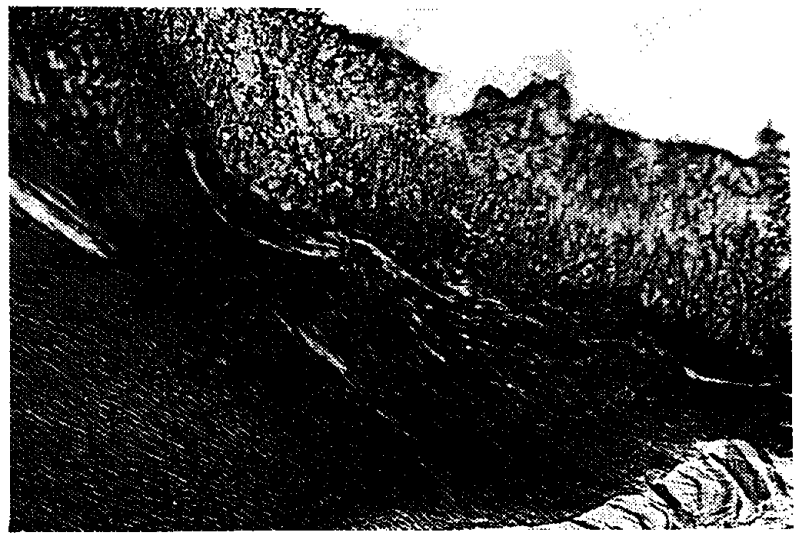

Fig. 20 On the 6th month

Silver Stain. $\times 100$

ント質の形成がみられ分岐根管も認められ，石灰化は完 了し根尖は閉鎖している（Fig．21）。㐘根の周囲には歯 根膜線維がとり囲み，ほぼ一定の幅をもち，エナメル・ セメント境から䍘根中央部まで無細胞セメント質の菲薄 な一層で雨根象牙質を覆っている．対照群の根尖部霜根 象牙質の発育，根尖閉鎖（Fig. 22）に比べ実駼群もほ ぼ同程度の所見を呈している。

神経線維についてみると，乙の時期に至ると下方の雪 䪔から上行してきた神経線維が dentin barrier の形成 部下方に至ると一部に蛇行, 屈曲が認められるものもあ るが，正常な形態を保ったまま，柵に平行に辺縁部の象 牙芽細胞層に終止するもの（Fig. 23，24）や柵内の料 髄の固有組織や血管とともに栅内に神経線維が進入して いる所芫もみられる．根尖部はセメント細胞を封入した 有細胞セメント質により閉鎖され，根尖歯根膜の神経叢 より分岐した中，小神経束が分岐根管を通じて歯髄内に 進入するようになる（Fig. 25）。

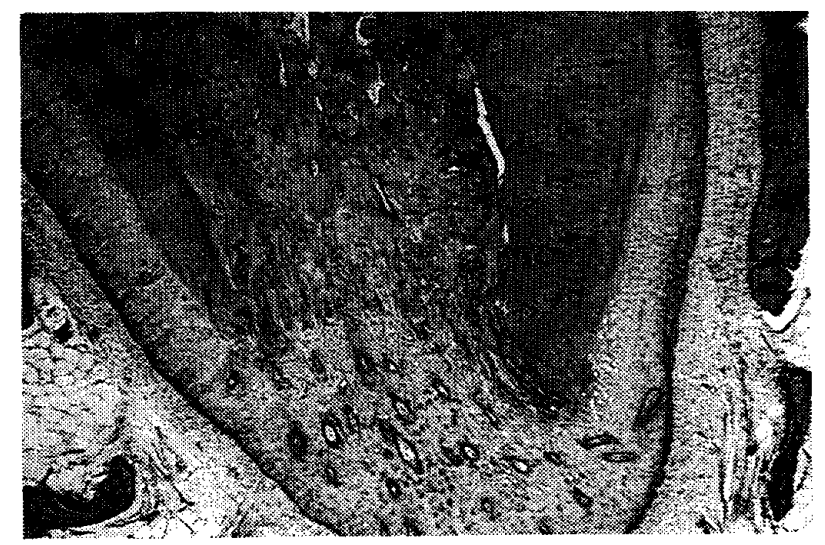

Fig. 21 On the 6th month $\mathrm{H} \cdot \mathrm{E}$ stain. $\quad \times 20$

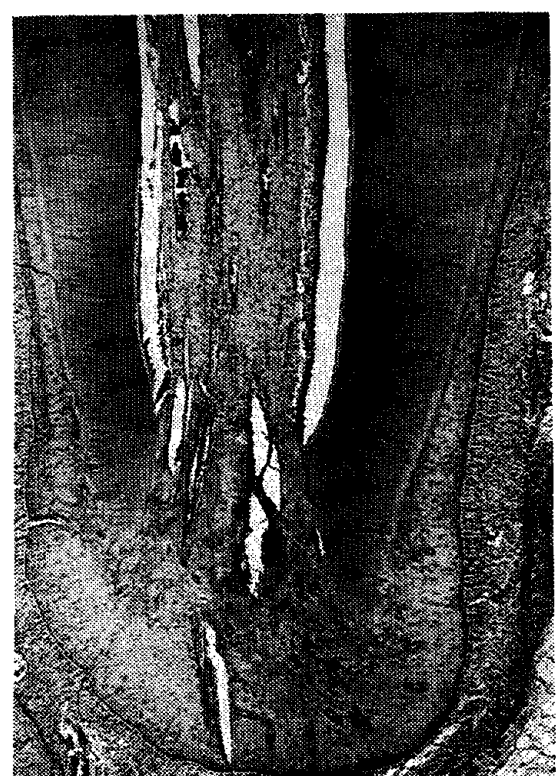

Fig. 22 On the 6th month

Control group H $\cdot$ E stain. $\times 20$

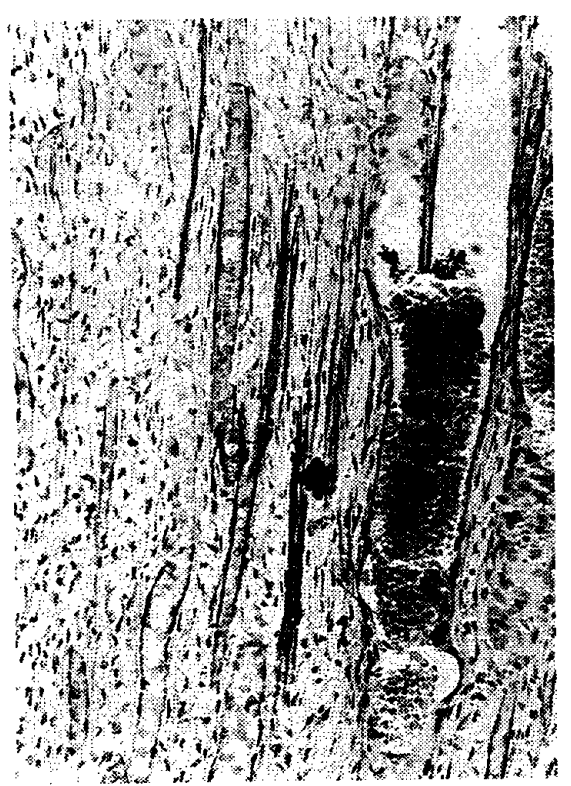

Fig. 23 On the 6th month

Stain for nerve fibers. $\times 100$

柬根膜は実験群（Fig．26)ならびに対照群 (Fig. 27) に示しているように歯根膜線維の走行は規則正しくセメ ント質から苗槽骨に斜走し，機能的配列を示しているの が明瞭である。

II. 電子顕微鏡的所見

A. 走查電影的所見

術後 2 週間

切断面に形成された dentin barrier の形成開始所見 の部を㐘㕼側より観察すると，類円形を呈した大小の石 


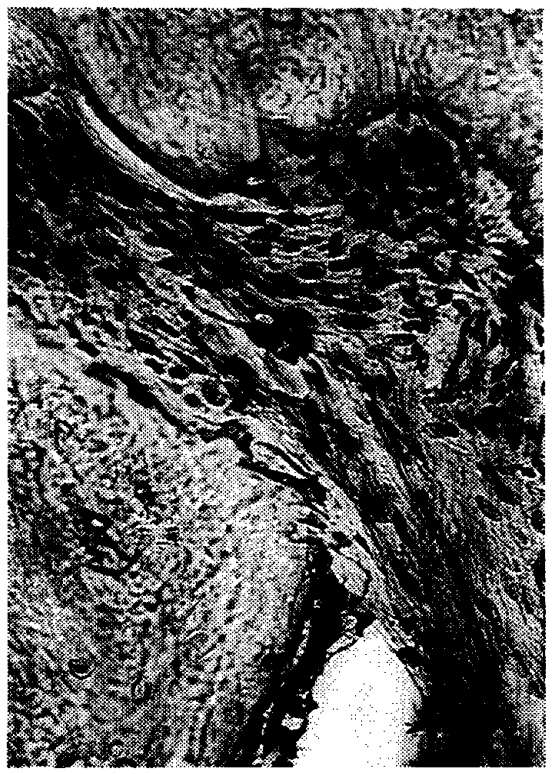

Fig. 24 On the 6th month

Stain for nerve fibers. $\times 100$

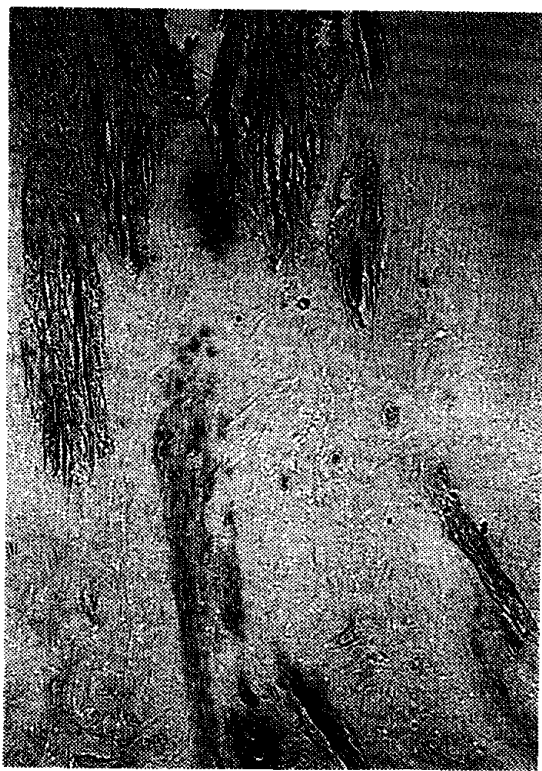

Fig. 25 On the 6th month

Stain for nerve fibers. $\times 100$

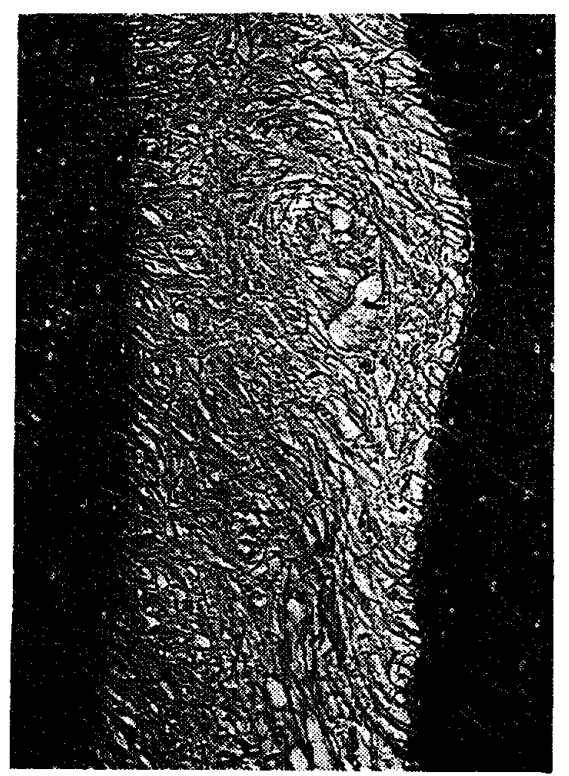

Fig. 26 On the 6 th month

Silver stain. $\times 100$

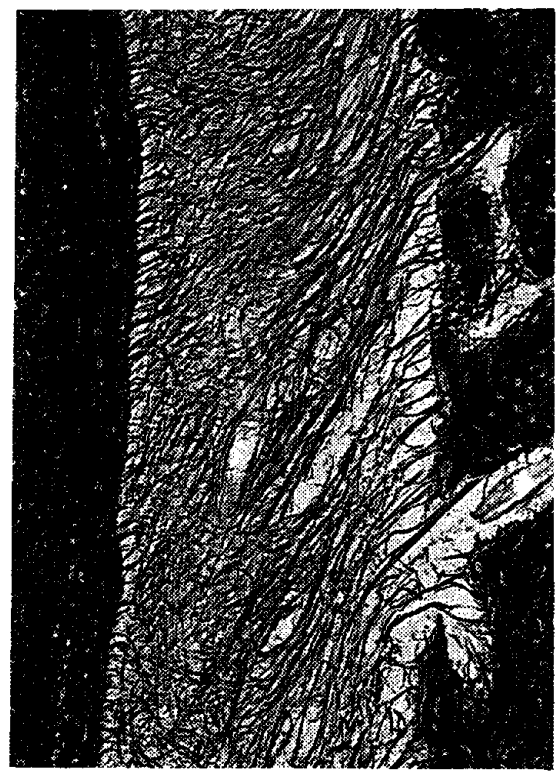

Fig. 27 On the 6th month

Control group Silver stain. $\times 100$
死化球椂構造物が互いに癒合し，重なり合って集合して いる．また，石灰化球様構造物との間には多数の間隙が 認められ，その部には多数の顆粒状沈着物も散見される

(Fig. 28).

術後 1 力月

切断面に形成された dentin barrier を茵冠側より観 察すると，辺緣部から雨髄中央部に連続して Fig. 29 亿 示すように比較的平滑面が多く認められる，平滑面は結 晶構造物により瘉合し, 緻密さを増している。粗造面に
は大小の顆粒状構造物が散在し, 線維様構造物はほとん ど認められない。また， dentin barrier を歯髄側から みると, 象牙細管の開口部がよく観察でき, 不規則では あるが，管周象牙質が識別され，基質との境界が明瞭な ところと不明瞭な所がある（Fig．30）。

術後 2 力月

この時期になると一般に切断面に形成された dentin barrier は崡根の原生象牙質とほぼ均等な緻密さを呈し ている.との dentin barrier 縦断すると，表層部は 


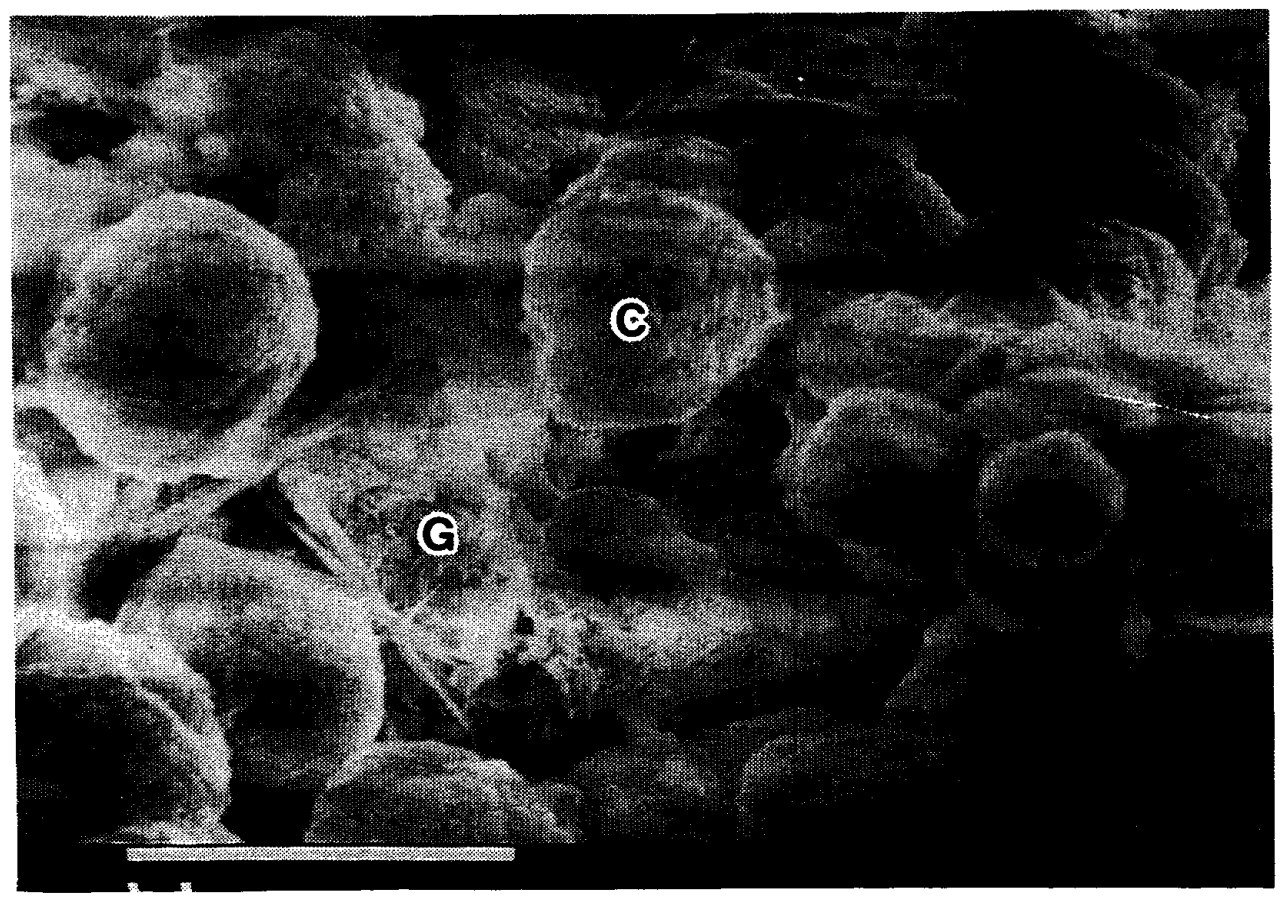

Fig. 28 On the 2nd week

C : Calcospherite-like structure

G : Granule deposits

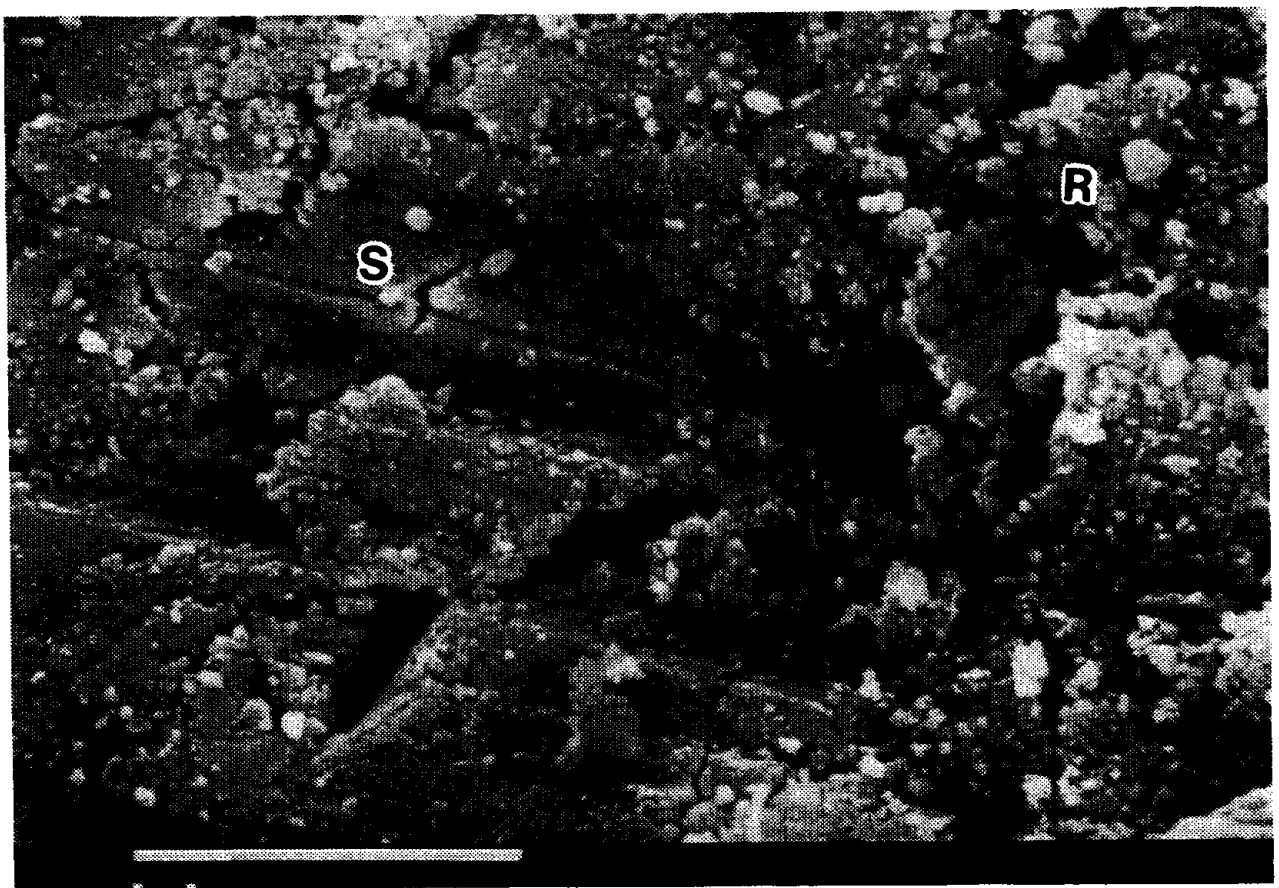

Fig. 29 On the 1st month

$S$ : Smooth surface

R : Rough surface

Fusion of crystal-like strucure 


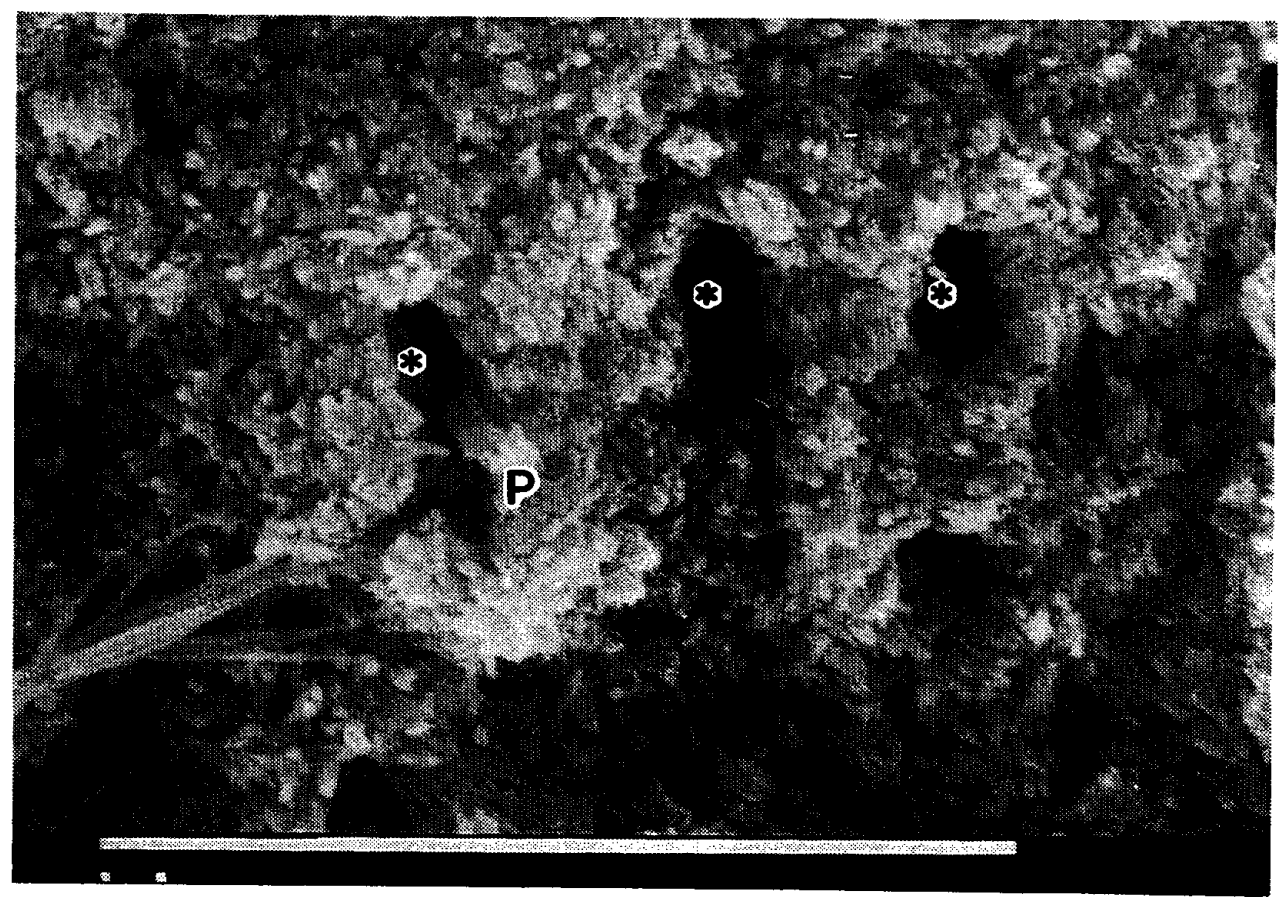

Fig. 30 On the 1st month

P : Peritubular dentin

* : Opening of dentinal tubules

大部分平滑面で占められ，多孔性を呈している，その内 部を観察すると，その部には結晶構造物が瘑合し間隙部 を満たしている．結晶構造物は密なコラーゲン成分によ って被われているのが明瞭である（Fig. 31）。乙の時期
になると dentin barrier は蒾根象牙質と瘁合するよう になる. dentin barrier の辺縁部を歯髄側より観察す ると，小孔が多くみられ石灭化球が瘾合し，緻密さを増 している，象牙細管構造は不均一でその数も少なく形成

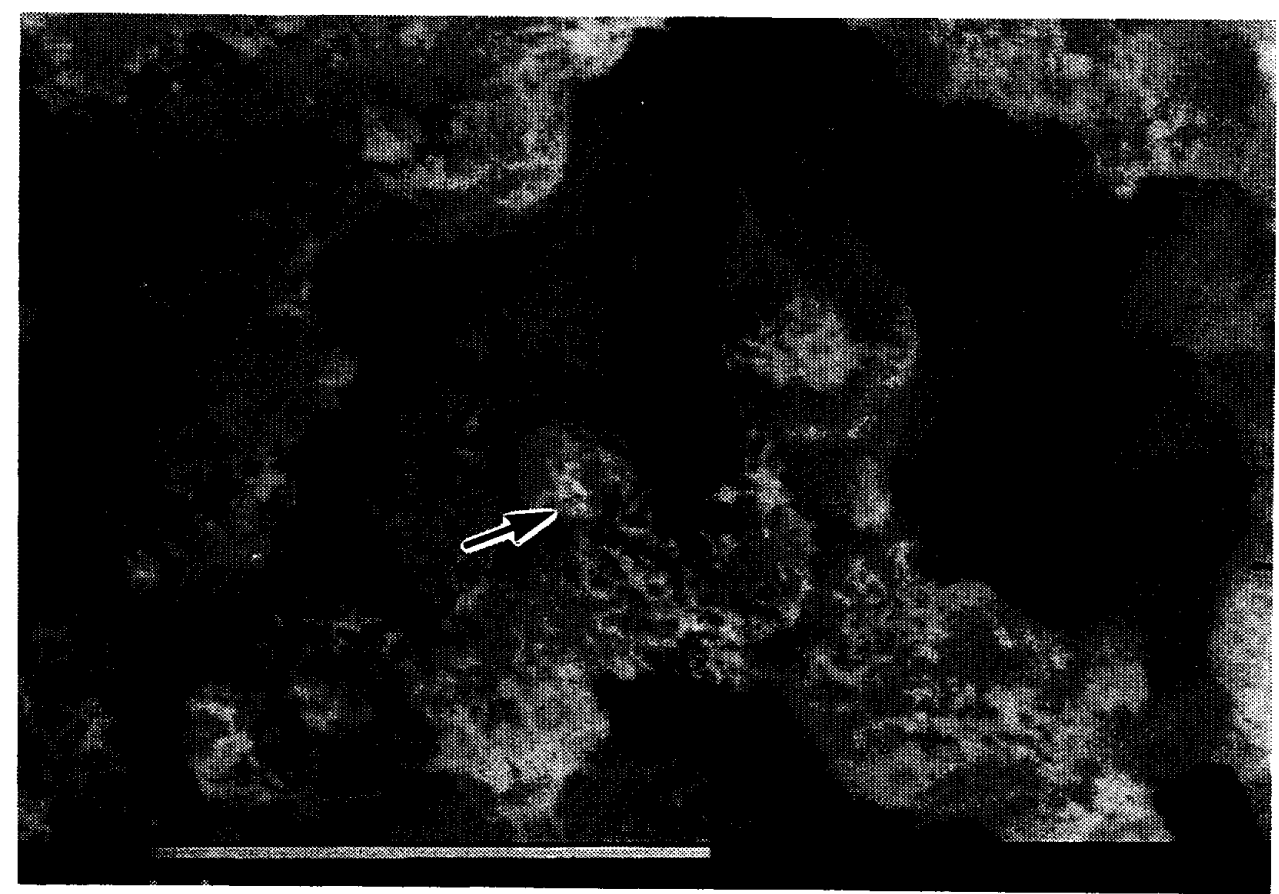

Fig. 31 On the 2nd month

$\uparrow:$ Calcified structure covered with collagen component 
の途上にある (Fig. 32).

根尖部に形成されるセメント質についてみると，対照 群ではセメント質表面は全般にわたって石灰化が進行中 であるが，石死化度の高いセメント質面が部分的に形成 されている所もみられ，線維成分に富んだ部分もみられ
る、実験群では対照群とほほ同様の所見を呈している (Fig. 33).

術後 6 力月

切断面の dentin barrier は平滑面を呈し, 函根象牙 質と癒合し，歯根象牙質と dentin barrier の厚さはほ

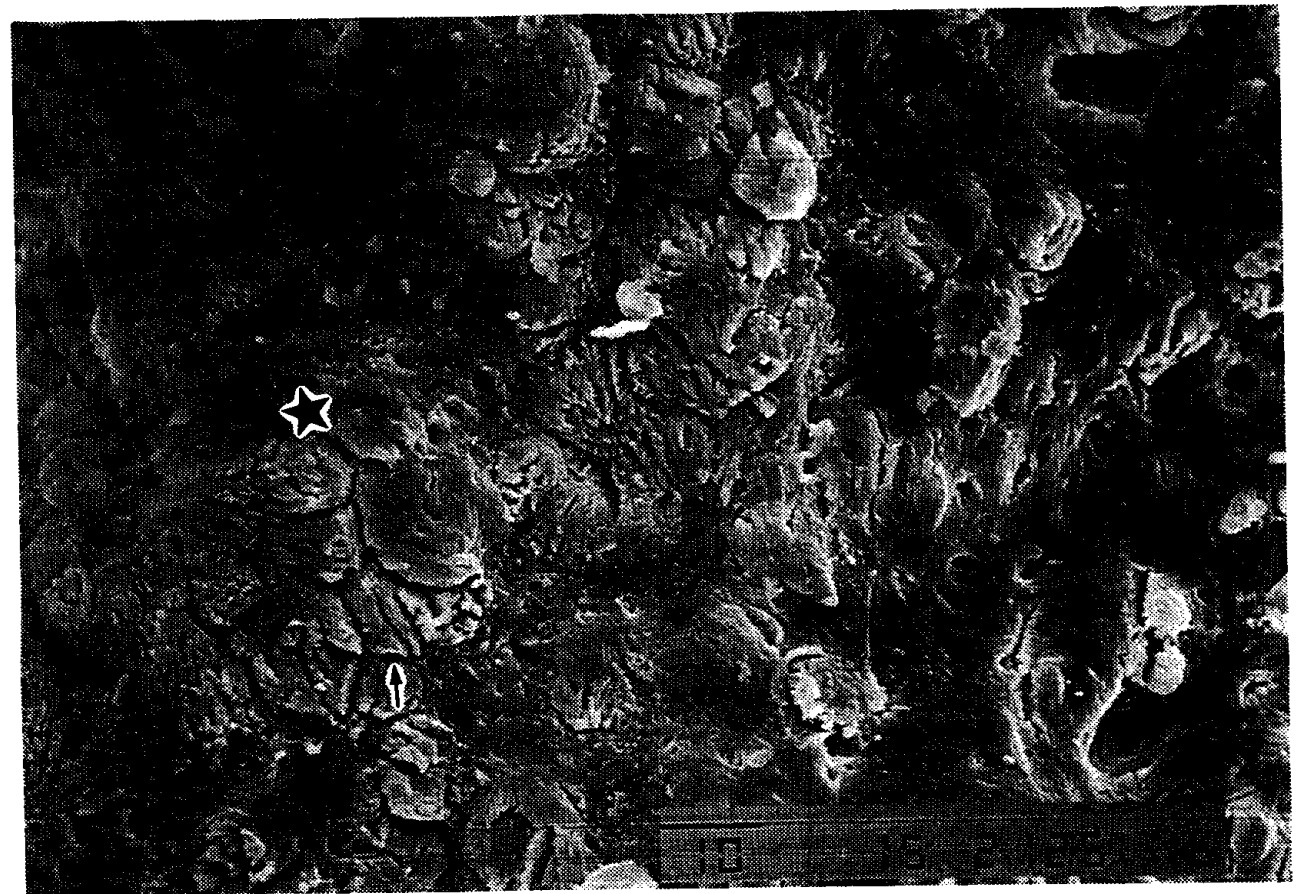

Fig. 32 On the 2nd month Fusion of calcosphrite

$\uparrow$ : Structure of dentinal tubules

*: foraminas

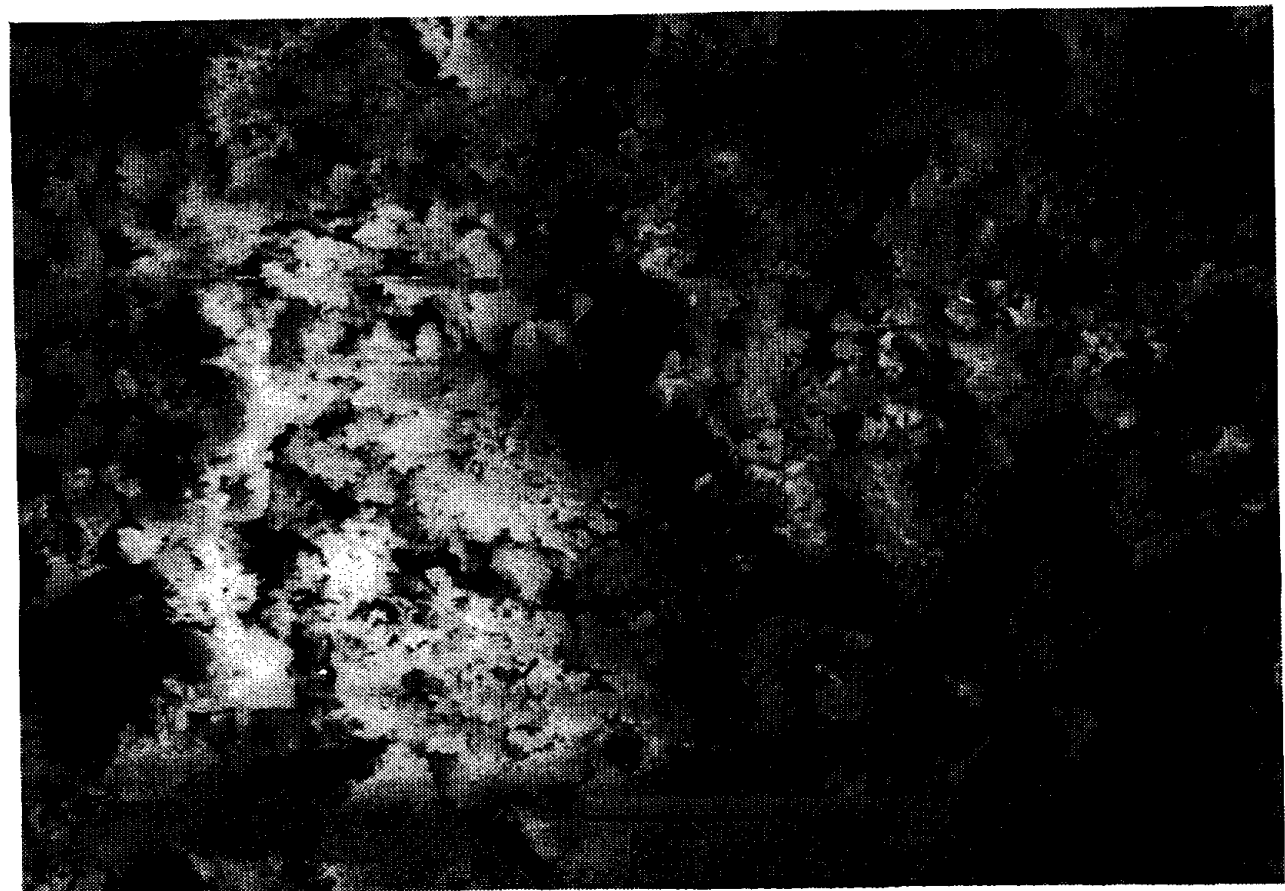

Fig. 33 On the 2nd month Rich with collagen fibril 
ぼ均等である（Fig. 34）.との dentin barrier を歯髄 側より観察すると, 石灰化球がほぼ規則正しく分布して いる．石灰化球は癒合し緻密さを増し均一な象牙細管構 造を有しているのが明瞭である (Fig. 35).
根尖部のセメント質についてみると，対照群は，根尖 部セメント質表面は全体的に平滑面を形成し, 直径 5 $\mu \mathrm{m} \sim 60 \mu \mathrm{m}$ の小孔が多数認められる (Fig. 36). Fig. 36 の一部を拡大すると, 直径約 $40 \mu \mathrm{m} \sim 60 \mu \mathrm{m}$ の分岐根

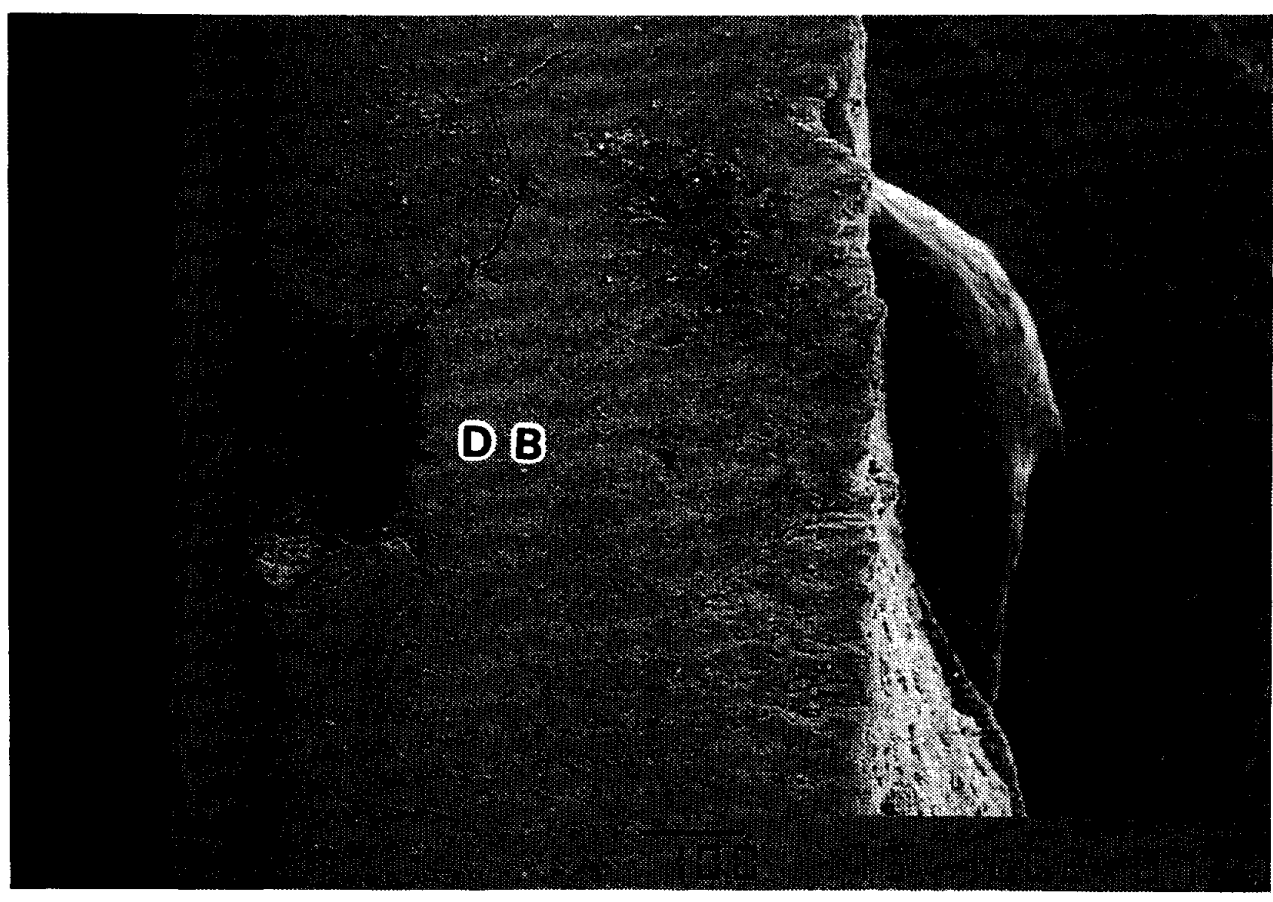

Fig. 34 On the 6 th month

DB : Dentin barrier

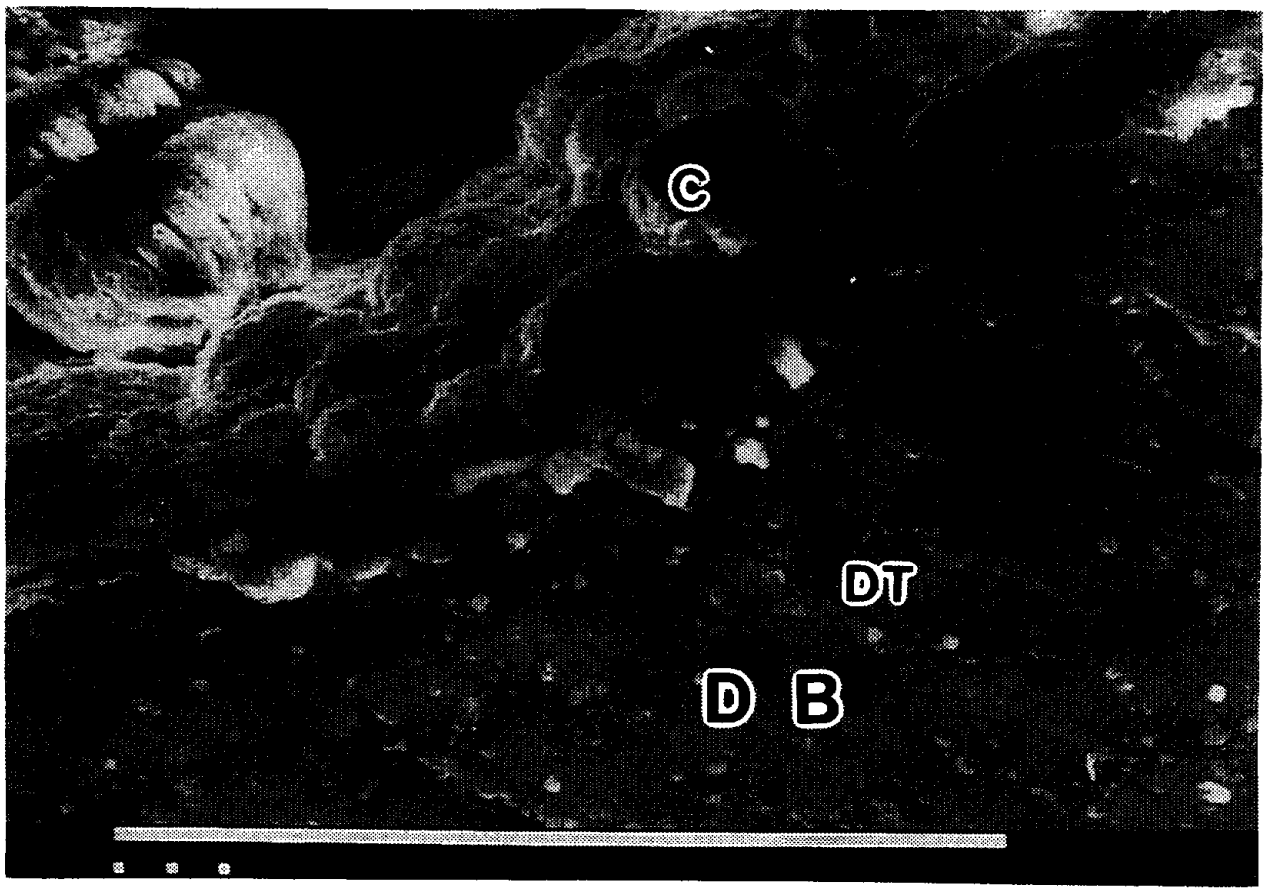

Fig. 35 On the 6th month Pulpal side of dentin barrier

C:Calcospherite DB:Dentin barrier DT : Dentinal tubules 
管の開口部がみられる。また，小窩も認められ，石灰化 小球は密江集合し表面は緻密さを増している(Fig. 37). Fig. 38 はセメント小腔を示しており，小腔壁はほぼ平
滑面を呈し，石灰化度の高い辺縁によって囲まれている が境はやや不明瞭である．小腔底部は基質原線維によっ て形成され，数個のセメント 細管の開口部が認められ

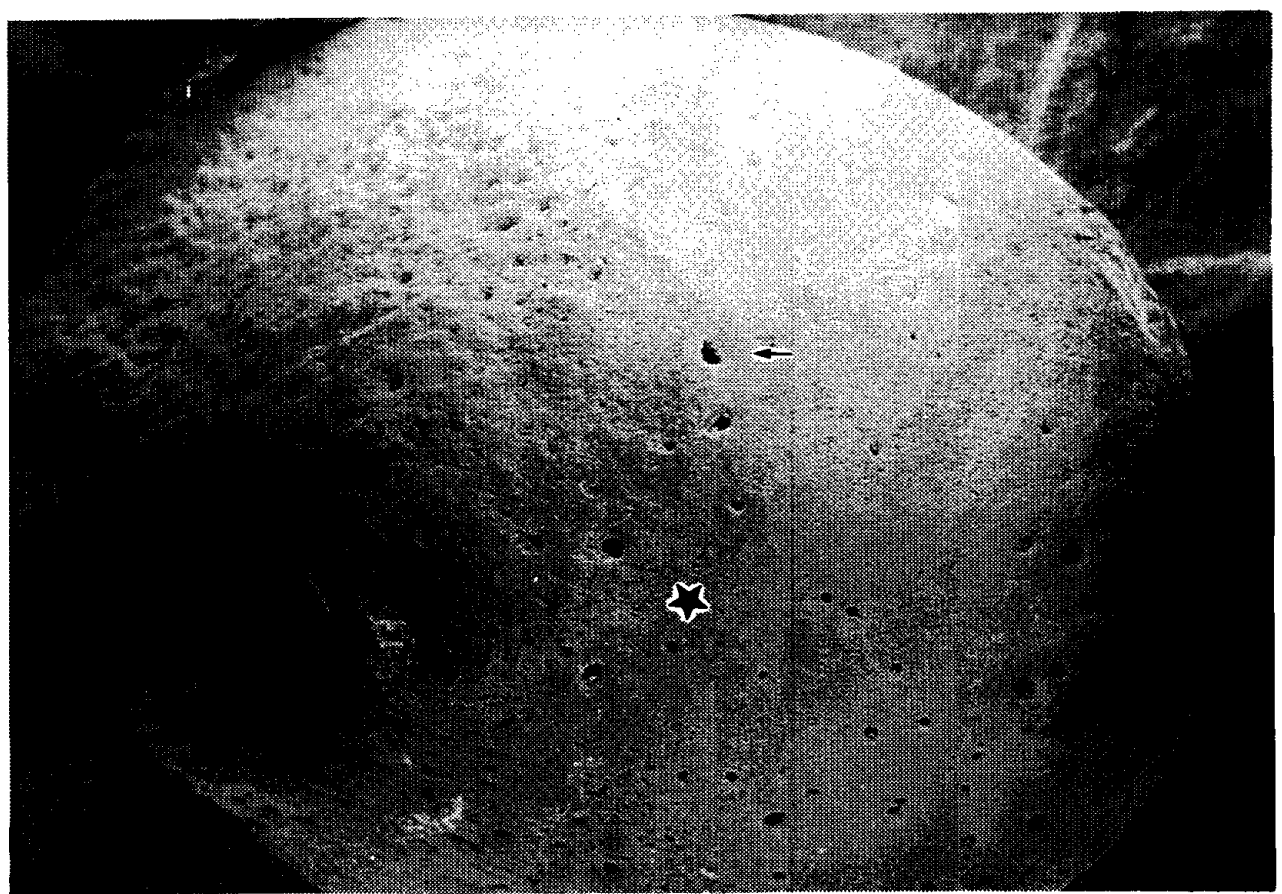

Fig. 36 On the 6th month

$\star$ : Smooth surface

$\uparrow$ : foraminas $\times 75$

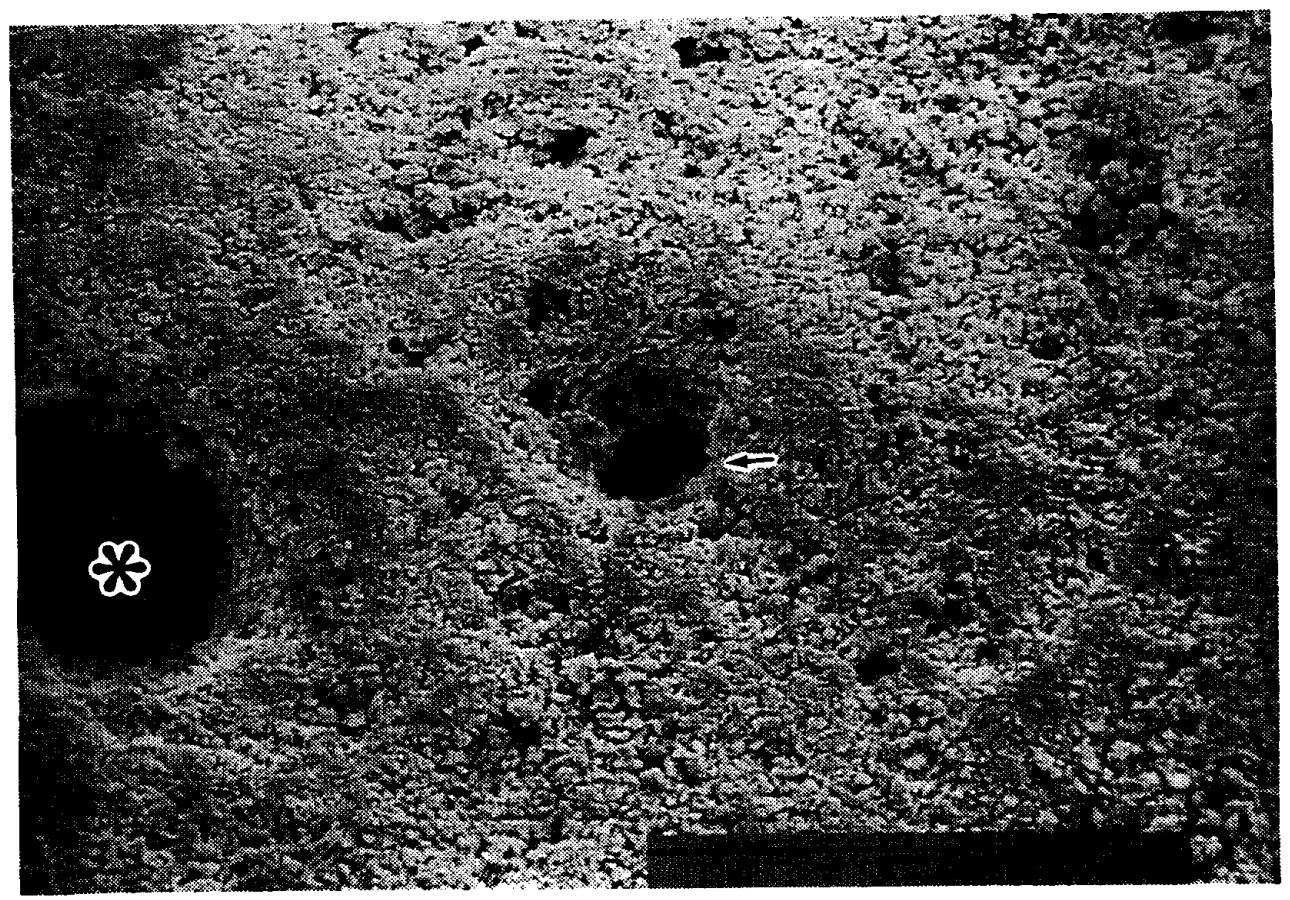

Fig. 37 On the 6th month

* : Opening of ramificated canal

$\uparrow:$ Pit 
る、根尖部に形成されたセメント質に接する茵根膜面を 観察すると，Fig. 39 亿示すように円形または楕円形を 示す Sharpey 線維束の横断像がみられ, 辺縁は石灰化
した基質原線維によって囲まれている。セメント小腔に は数個のセメント細管の開口部が認められる。

実験群についてみると, 根尖部に形成されたセメント

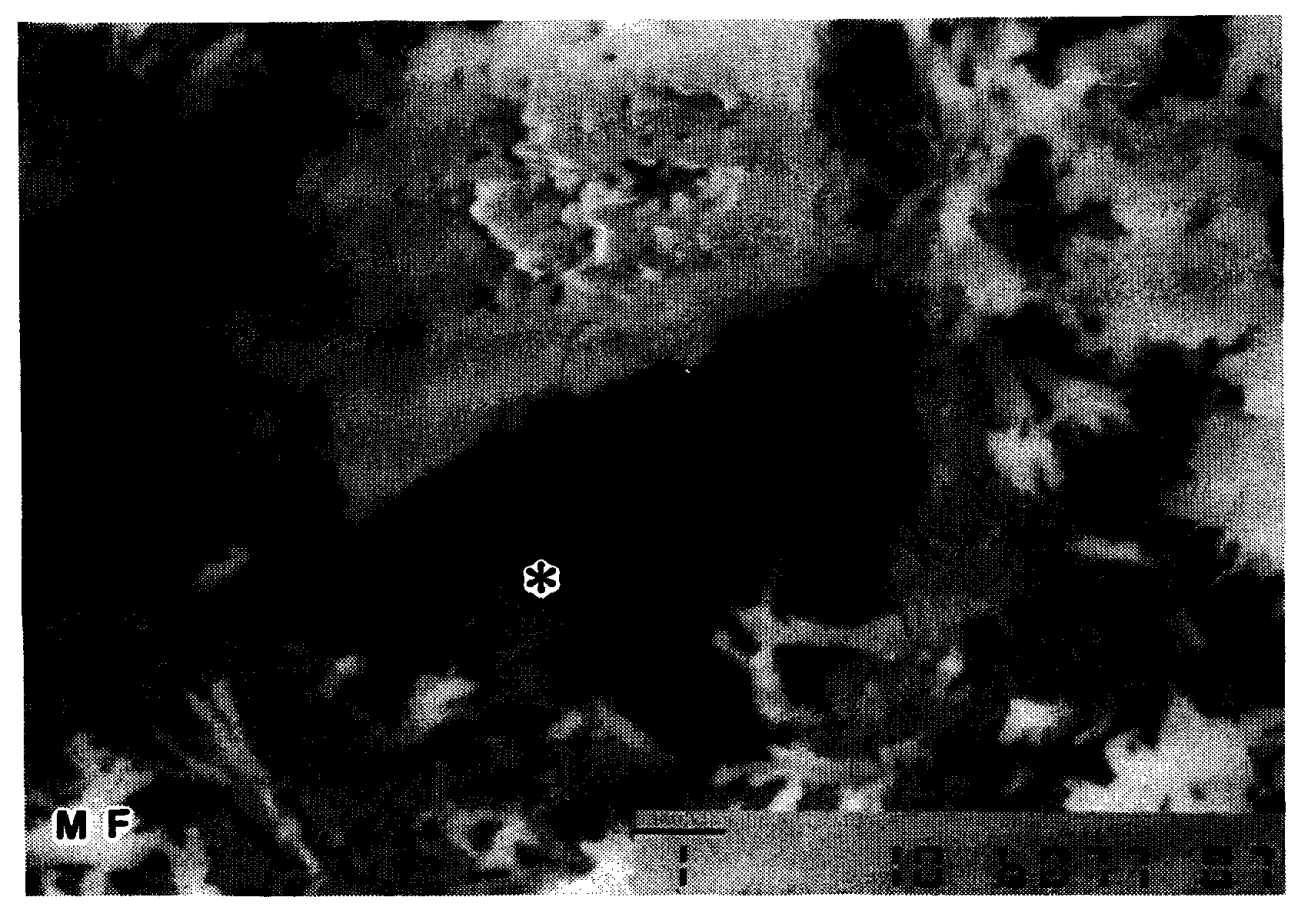

Fig. 38 On the 6th month Cementum lucunae * : Opening of cementum canaliculi MF : Matrix fibril

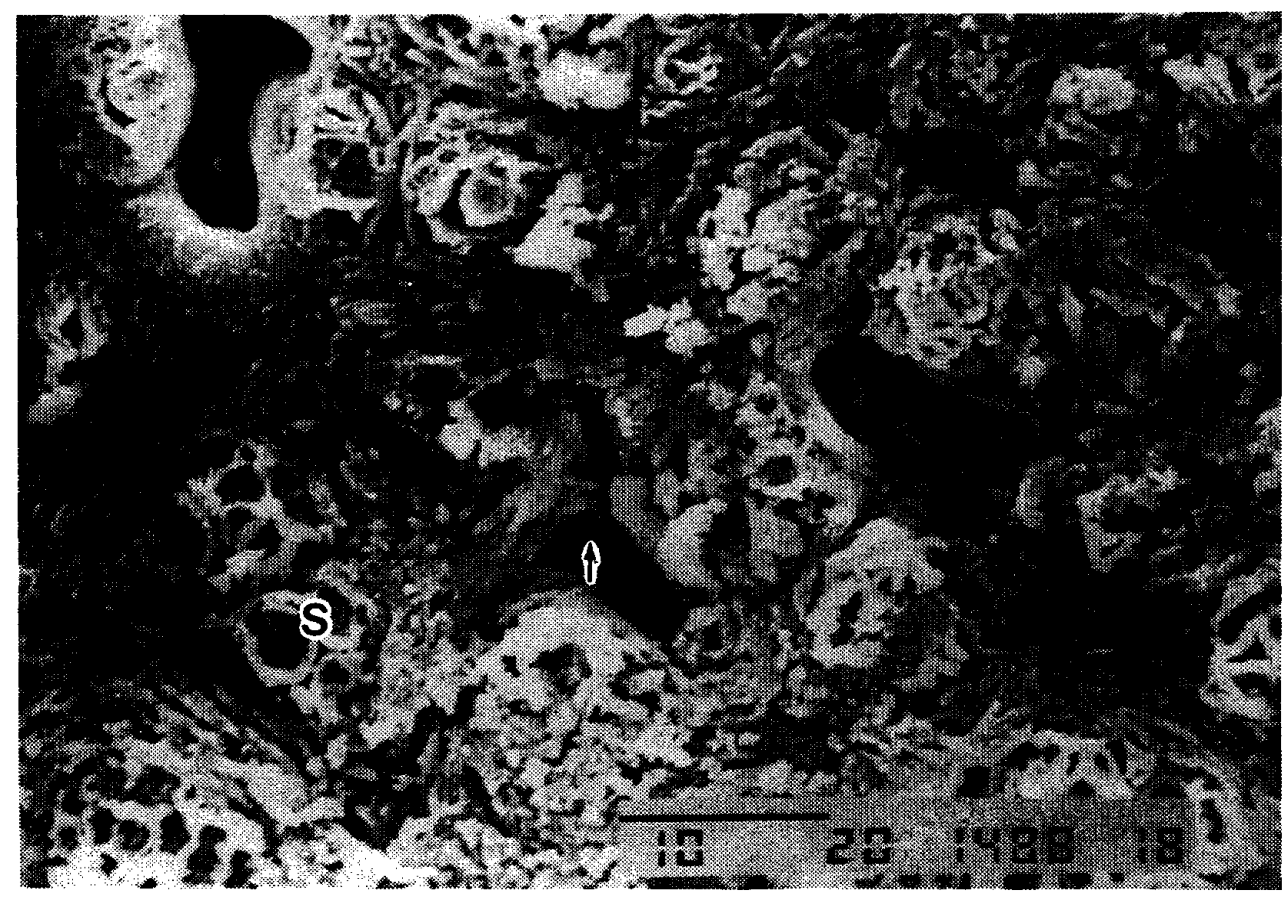

Fig. 39 On the 6th month

$\uparrow:$ Cementum canaliculi

$S$ : Bundles of Sharpey fibril 
質はFig. 40 に示すように全体にわたって対照群と同 様に平滑面を形成している．直径約 $5 \mu \mathrm{m} \sim 60 \mu \mathrm{m}$ の小 孔が多数みられる（Fig. 40）.Fig. 40 の一部を拡大す
ると直径約 $40 \mu \mathrm{m} \sim 60 \mu \mathrm{m}$ 分岐根管の開口部がみられ， その周囲は微細な顆粒状構造物によって用まれている。 大小不同の小裔は $5 \mu \mathrm{m} \sim 10 \mu \mathrm{m}$ で形状の異なるセメン

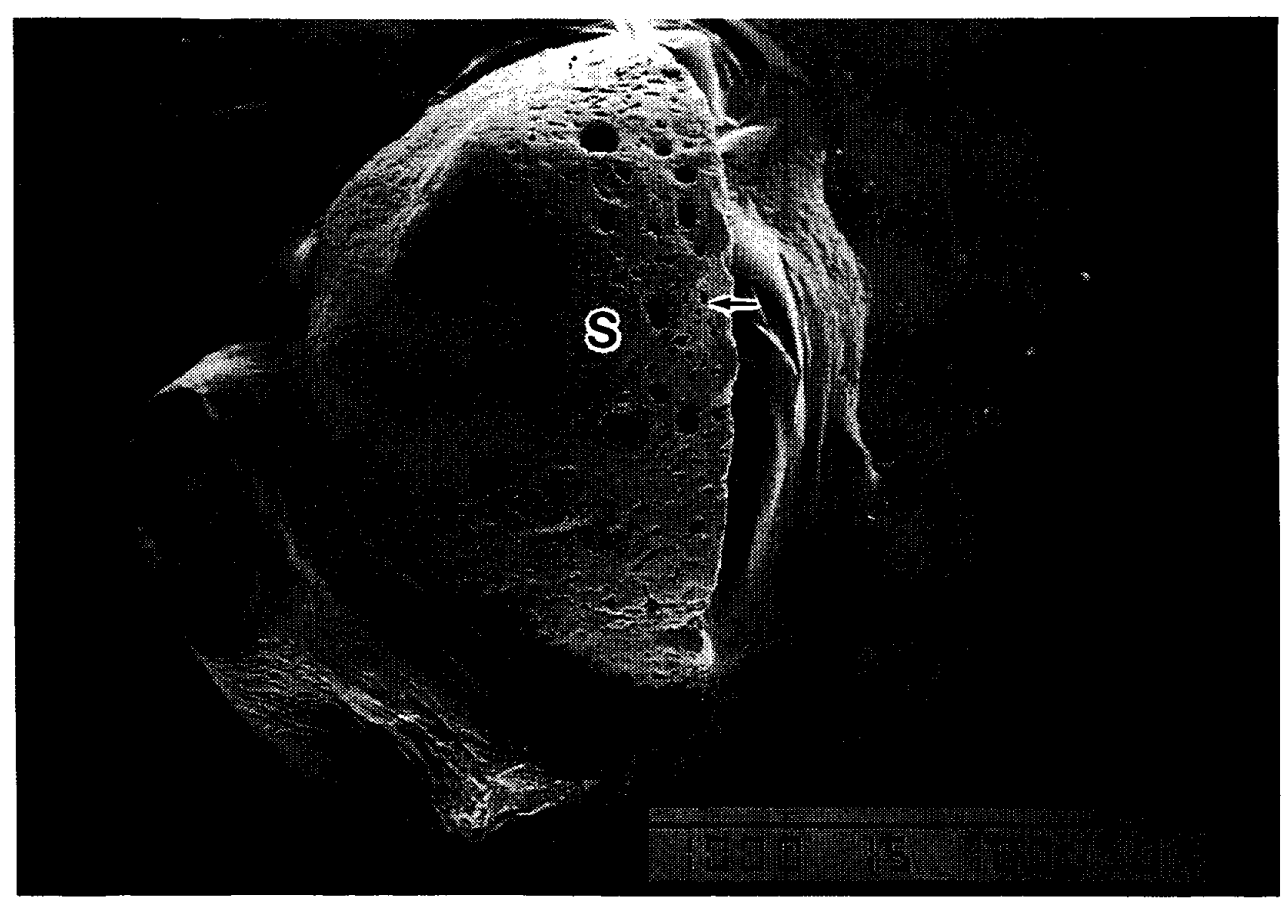

Fig. 40 On the 6th month

$\mathrm{S}$ : Smooth surface

\section{$\uparrow:$ foraminas}

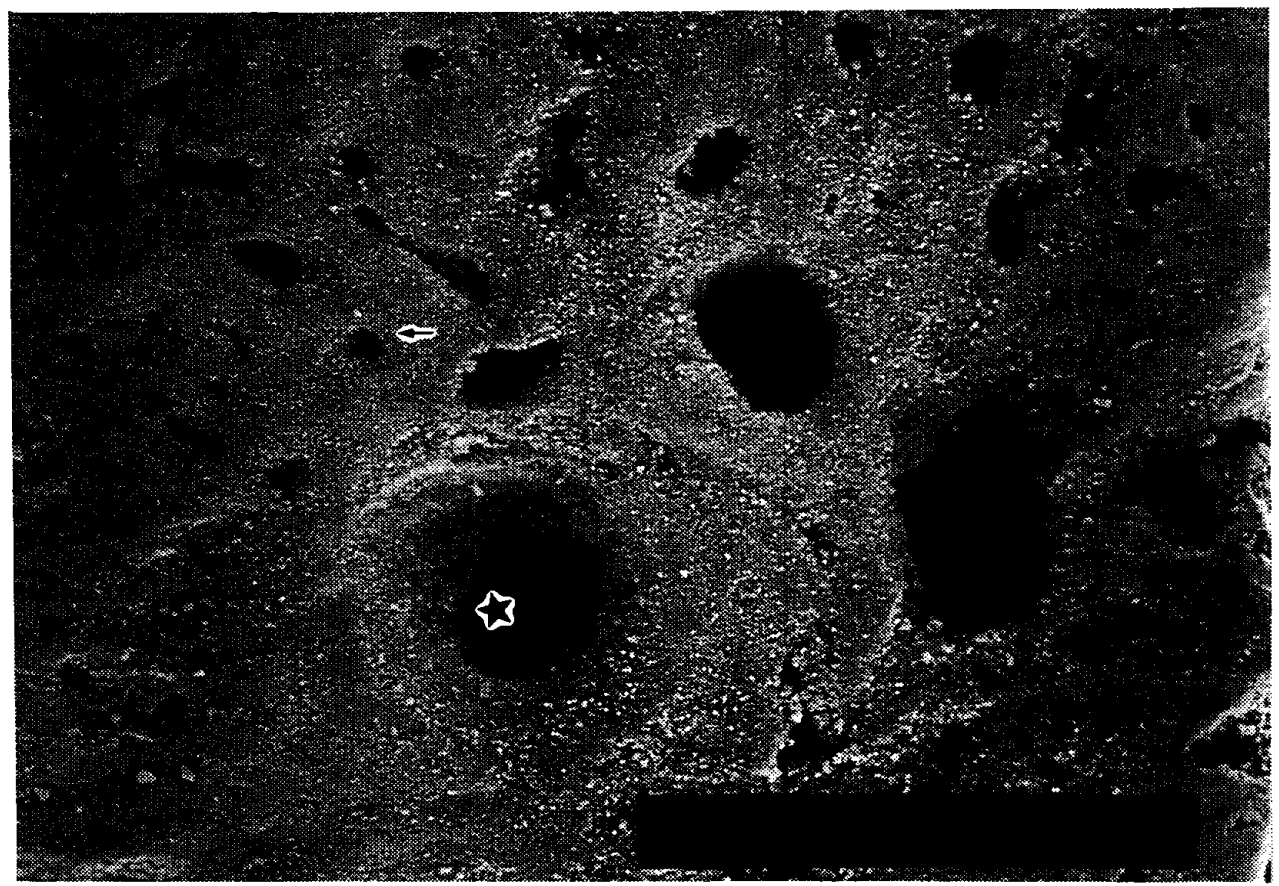

Fig. 41 On the 6th month

$\star$ : Opening of ramificated canal

$\uparrow:$ Pit 
ト小腔がみられる (Fig. 41).との時期に至るとセメン 卜質形成面にはセメント小腔が垫められるが，その周囲 は基質原線維によって井まれている，底部を観察する と，平坦な面で形成されており，その部には数個のセメ ント細管の開口部が認められる（Fig. 42）.

B . 透過電顕的所見

対照群

術後 3 日から 1 週間までは根尖部の新生象牙質表面に は, 大型の核をもち細胞質内に豊富な粗面小胞体とミト コンドリアをもつセメント芽細胞が認められ，細胞間隙 は比較的広い（Fig. 43）。根尖部表層のセメント芽細胞 を観察すると術後 2 週間から 2 力月目には大型の棈円形 の核をもち細胞質内には豊富な粗面小胞体とミトコンド リアが存在し, activeなセメント牙細胞が羿められる. 細胞間には多数のコラーゲン原線維が認められ，その中 に細胞質突起が認められる (Fig，44）。術後6力月に至 ると, セメント質表面にクロマチンの豊富な楕円形の核 をもち細胞質内にわずかな粗面小胞体とミトコンドリア を有するセメント芽細胞が認められ，セメント質に細胞 質突起を出し, いわゆる resting cell の状態を呈して いる（Fig. 45）。また，セメント質中には紐胞内にライ ソゾームと少数の粗面小胞体とミトコンドリアをもち細
胞小器官に乏しいセメント細胞が認められ，全体的に細 胞は暗調を呈している（Fig.46）。

術後 3 日から 2 力月に至るまで歯根膜の線維芽細胞は クロマチンに王しい卵円形の大型の核と細胞質内に多数 の粗面小胞体，ミトコンドリアが存在している（Fig. 47). 術後 6 力月に至ると線維芽細胞は大型の核をもち, ミトコンドリア，粗面小胞体が認められるが細胞小器官 にそしい，その周囲に多数のコラーゲン原線維束が認め られ，コラーゲン原線維束の走行に細胞の長軸を一致さ せている（Fig．48）。細胞外形には突起が少なく，扁平 な核と紐胞体をもつ細胞も珰められるようになる。

神経線維について観察するとシュワン細胞は軸索を含 み，細胞質内には比較的発達のよくない粗面小胞体と豊 箅な filament を含んでいるが，細胞小器官は少ない。 髄鞘はシュワン細胞の細胞膜の一部が蝶旋状にとりまい て層状構造が諗められる。その内部に軸索が浔められ る、軸索内に神経細線維, ミトコンドリア，神経細管が 認められ, 神経細線維, 神経細管は軸索の長軸と平行に 走行している. 神経線維の微細構造は, 実験期間を通じ て同様な所見を呈している（Fig.49）.

実験群

術後 3 日

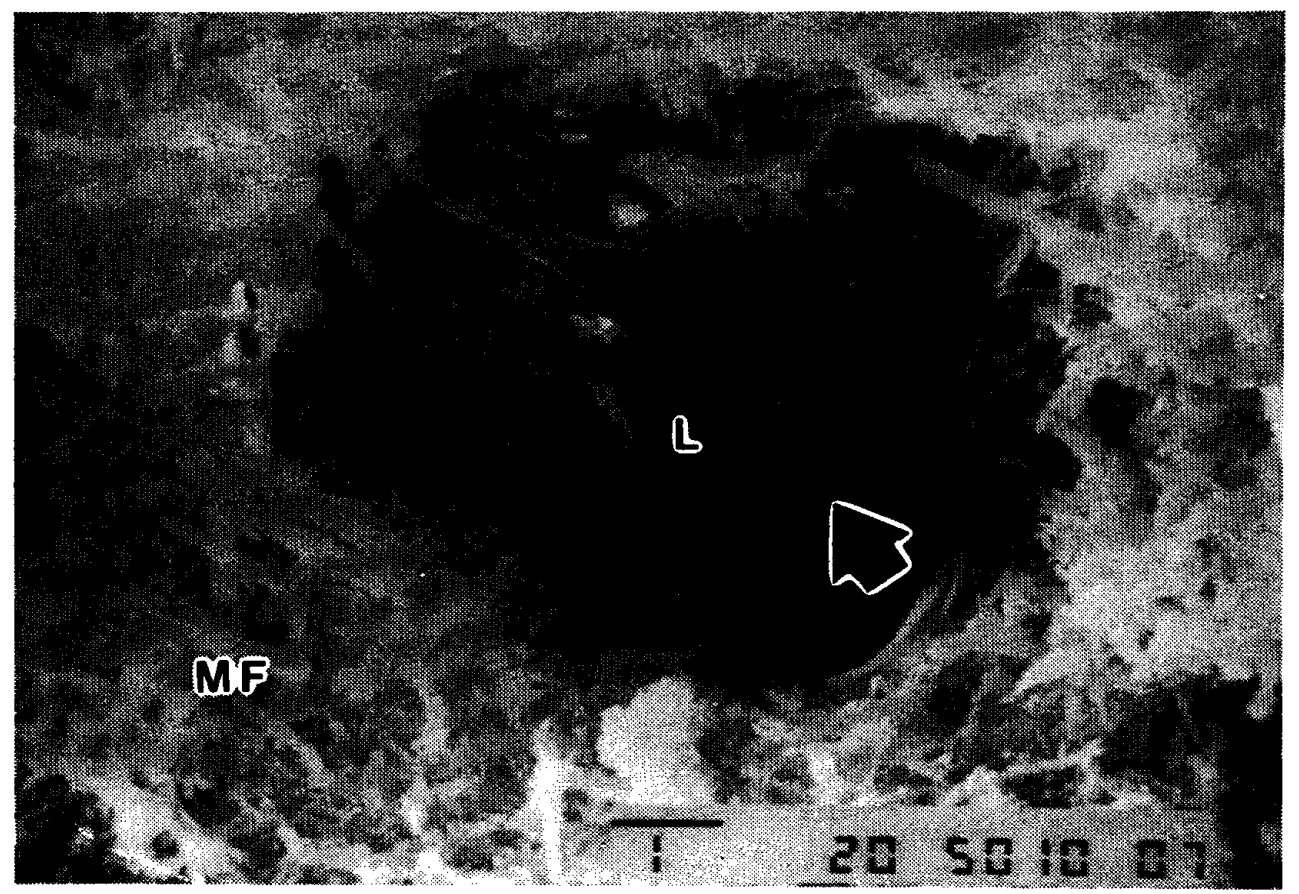

Fig. 42 On the 6 th month

^: Opening of cementum canaliculi

$\mathrm{L}$ : Cementum lacunae

MF : Matrix fibril 
切断面直下の炎症層付近の細胞を観察すると血管の周 囲には未分化間葉細胞が観察され細胞質内には大型の核 が認められるが，細胞小器官は乏しい，その周囲のコラ
ーゲン原線維は少ない（Fig. 50）。

切断面直下の歯䯣内の有㕼神経線維を観察すると, 鹃道 鞘のミエリン部の破壊は著明で鹃鞘内部の軸索は䯑道鞘の

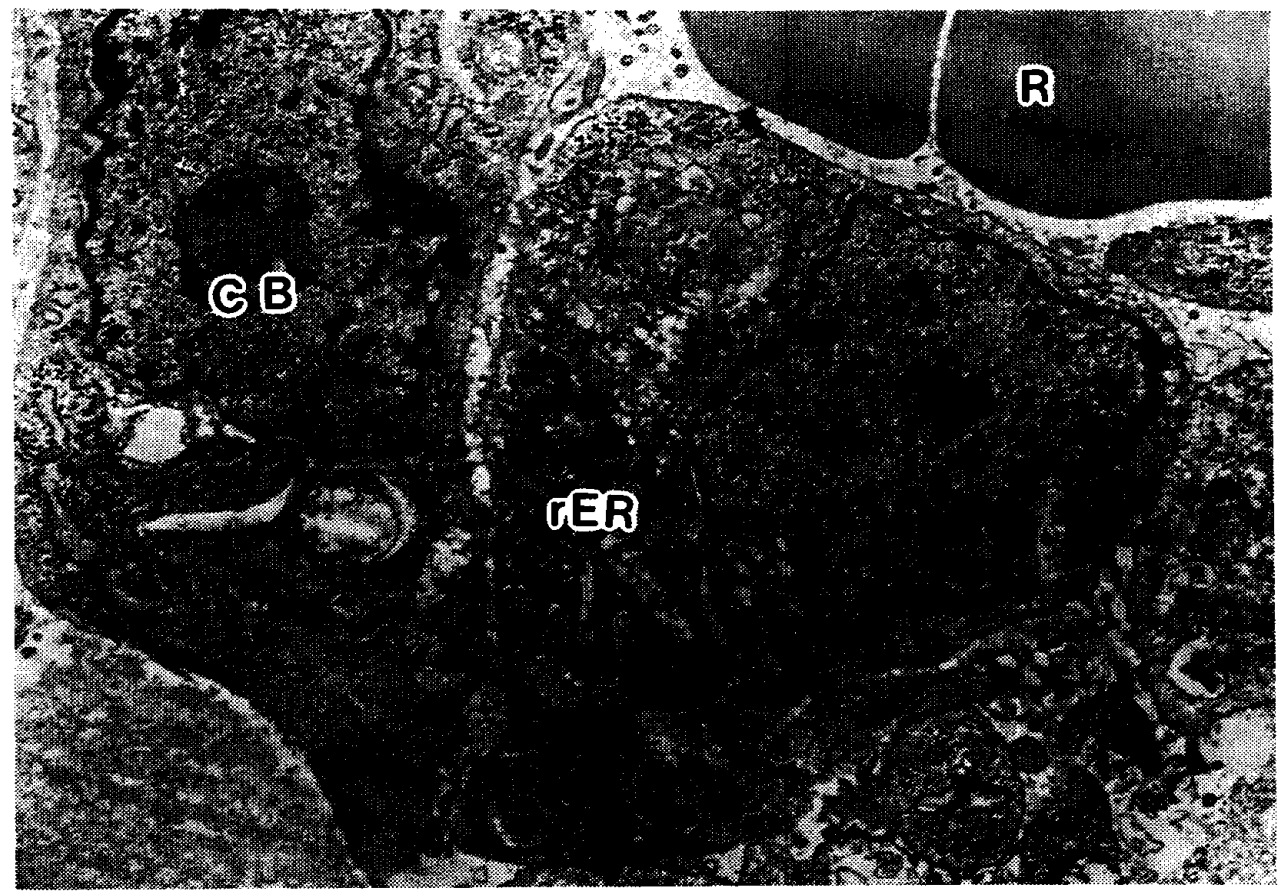

Fig. 43 On the 3rd day Control group

R : Red cell CB : Cementoblast

rER : rough surfaced endoplasmic reticulum $\times 6,600$

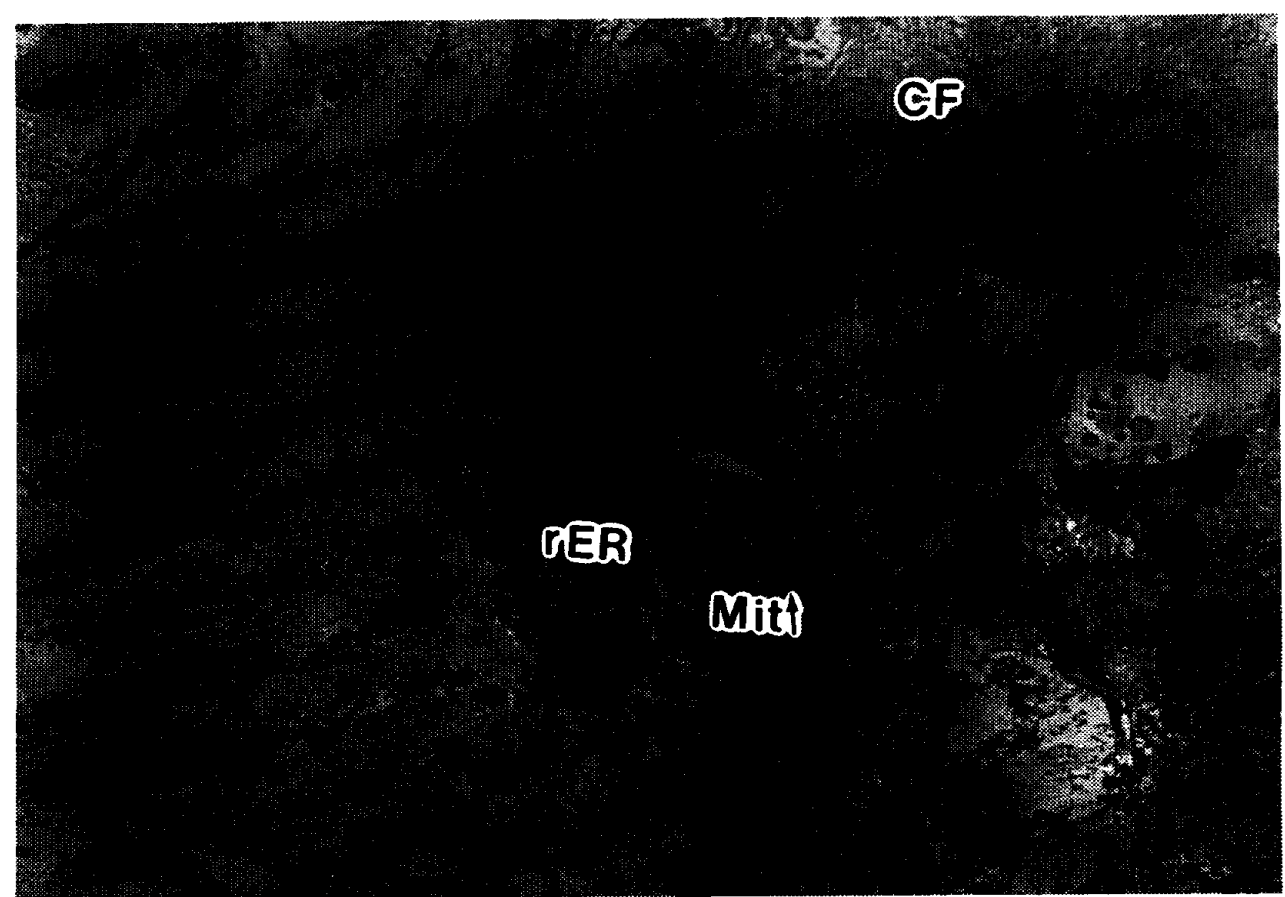

Fig. 44 On the 2nd week Control group

Mit : Mitochondria CF : Collagen fibril

rER : rough surfaced endoplasmic reticulum $\times 5,000$ 
変形に沿って一部変形が認められ，軸索と髄鞘には間隙 が認められ, 神経細管のわずかな減少が認められ神経細 線維も認められる (Fig. 51).

根尖部にみられるセメント牙細胞を観察すると，ク口 マチンに乏しい大型の楕円形の核をもち核小体の明瞭な
細胞が認められ，細胞質内には豊富な粗面小胞体とミ卜 コンドリアが認められる（Fig. 52）。乙の時期の柬根膜 の線維芽細胞を観察すると同時期の対照群と同様な所見 を呈しており，クロマチンに乏しい大型の類円形の核を もち細胞質内にはミトコンドリア，粗面小胞体が多数認

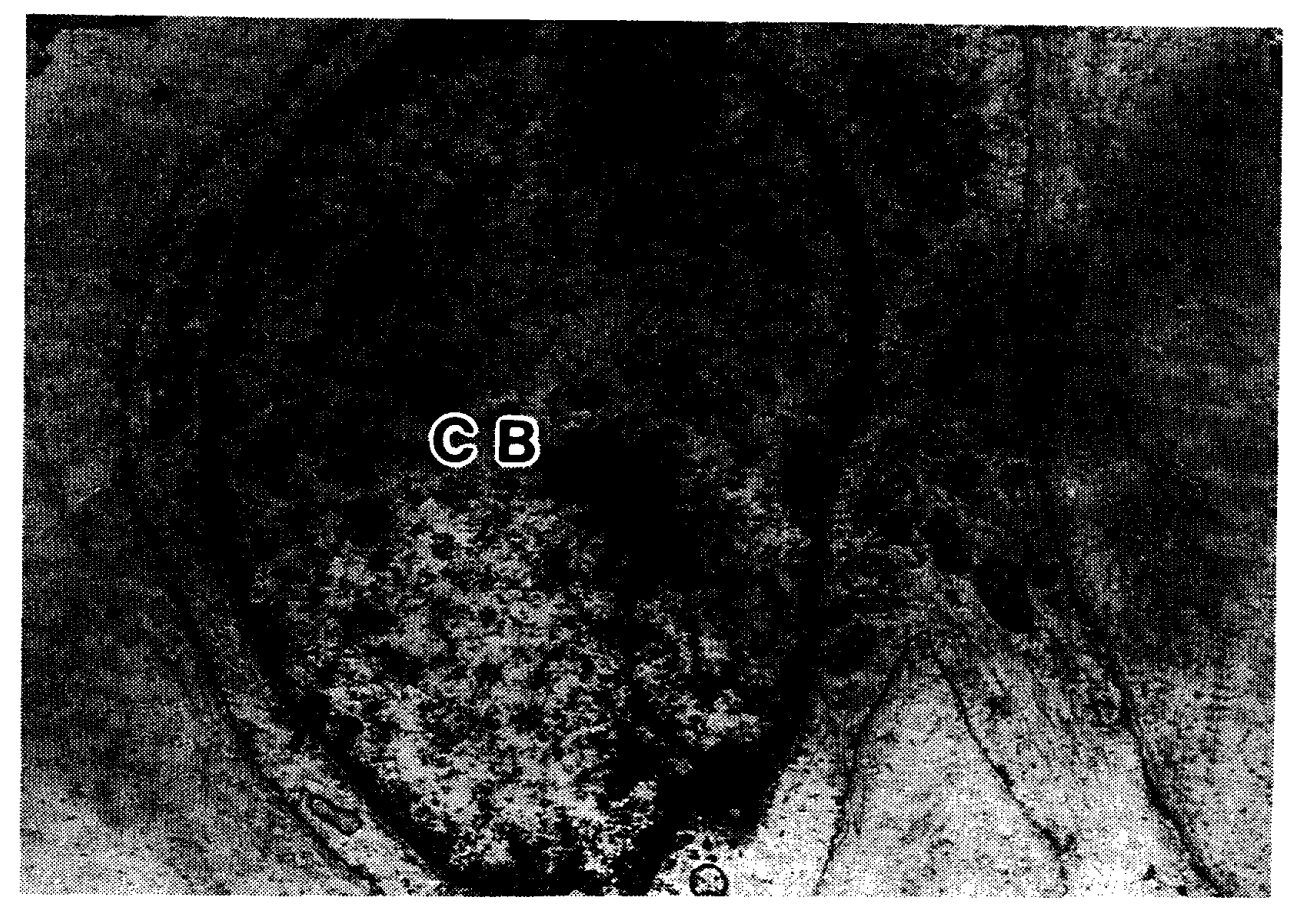

Fig. 45 On the 6 th month Control group

CB : Cementoblast $\times 6,600$

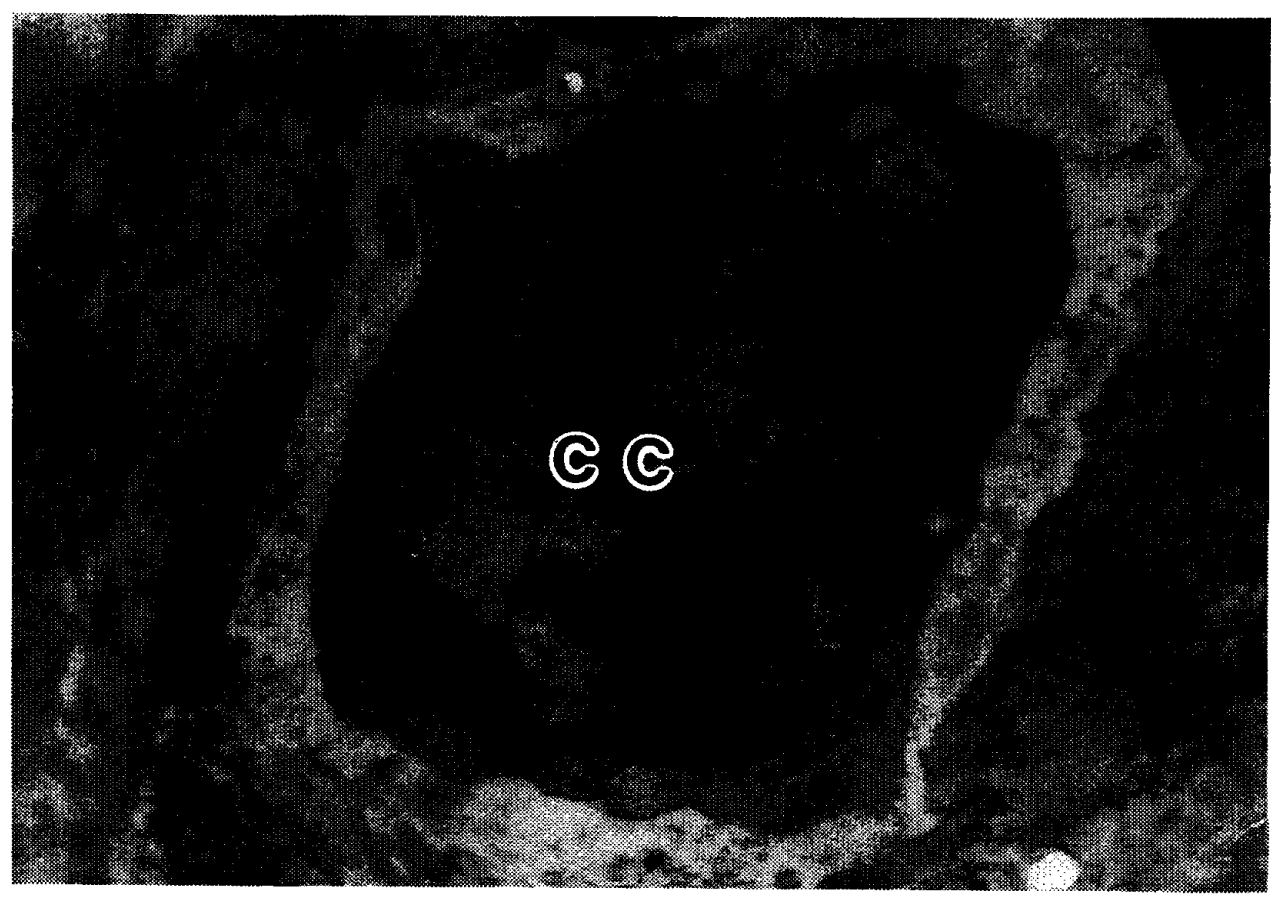

Fig. 46 On the 6th month Control group

$\mathrm{CC}:$ Cementocyte $\times 6,600$ 
められ，細胞問には縦横に走行する多数のコラーゲン原 線維が認められる（Fig. 53）。

術後 1 週間
切断面直下の歯随内には比較的核の占める割合が大き い多角形の細胞が認められる．核は部分的に小さな俩凹 が認められ，核をとり囲むように粗面小胞体が豊富に穀

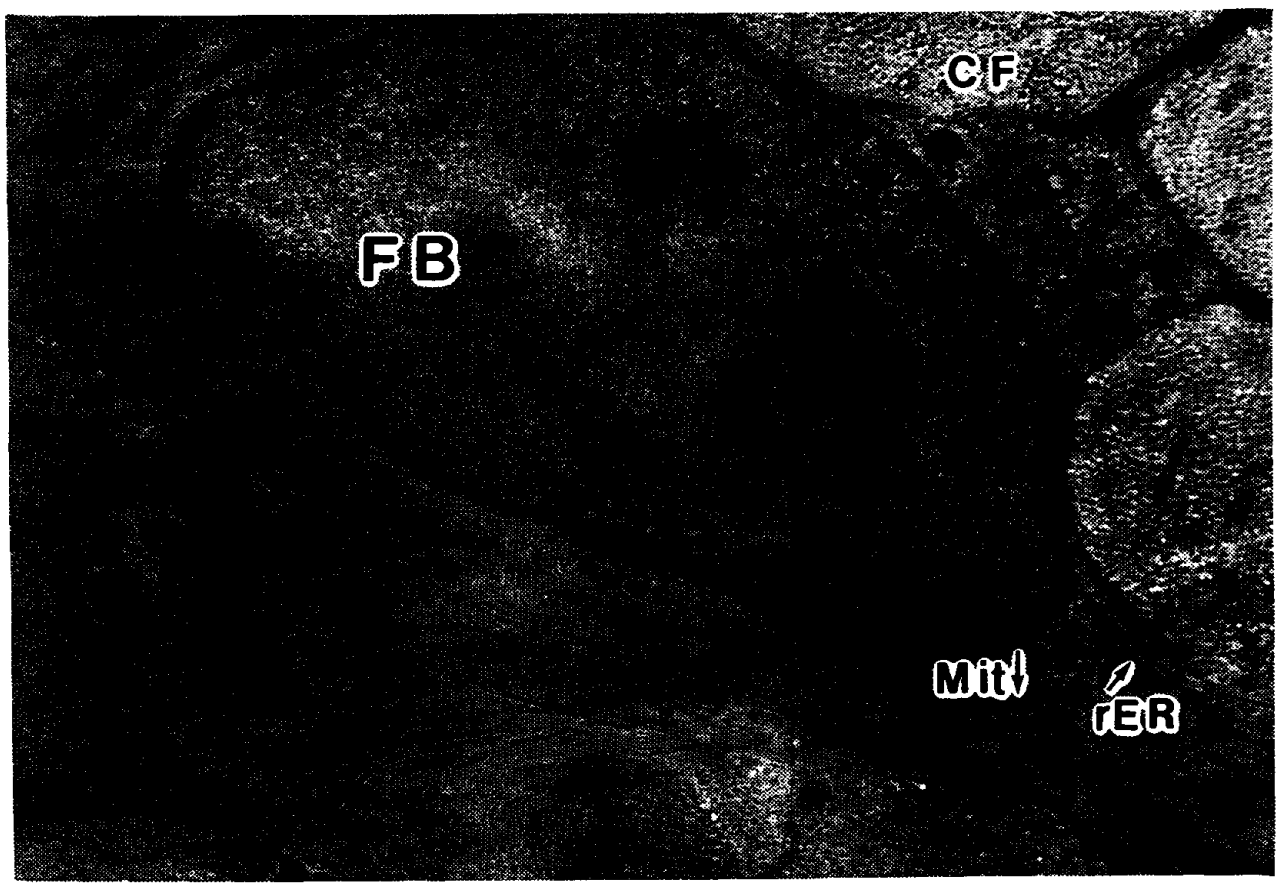

Fig. 47 Periodontal ligament Control group FB : Fibroblast CF : Collagen fibril rER : rough surfaced endoplasmic reticulum Mit : Mitchondria $\times 6,600$

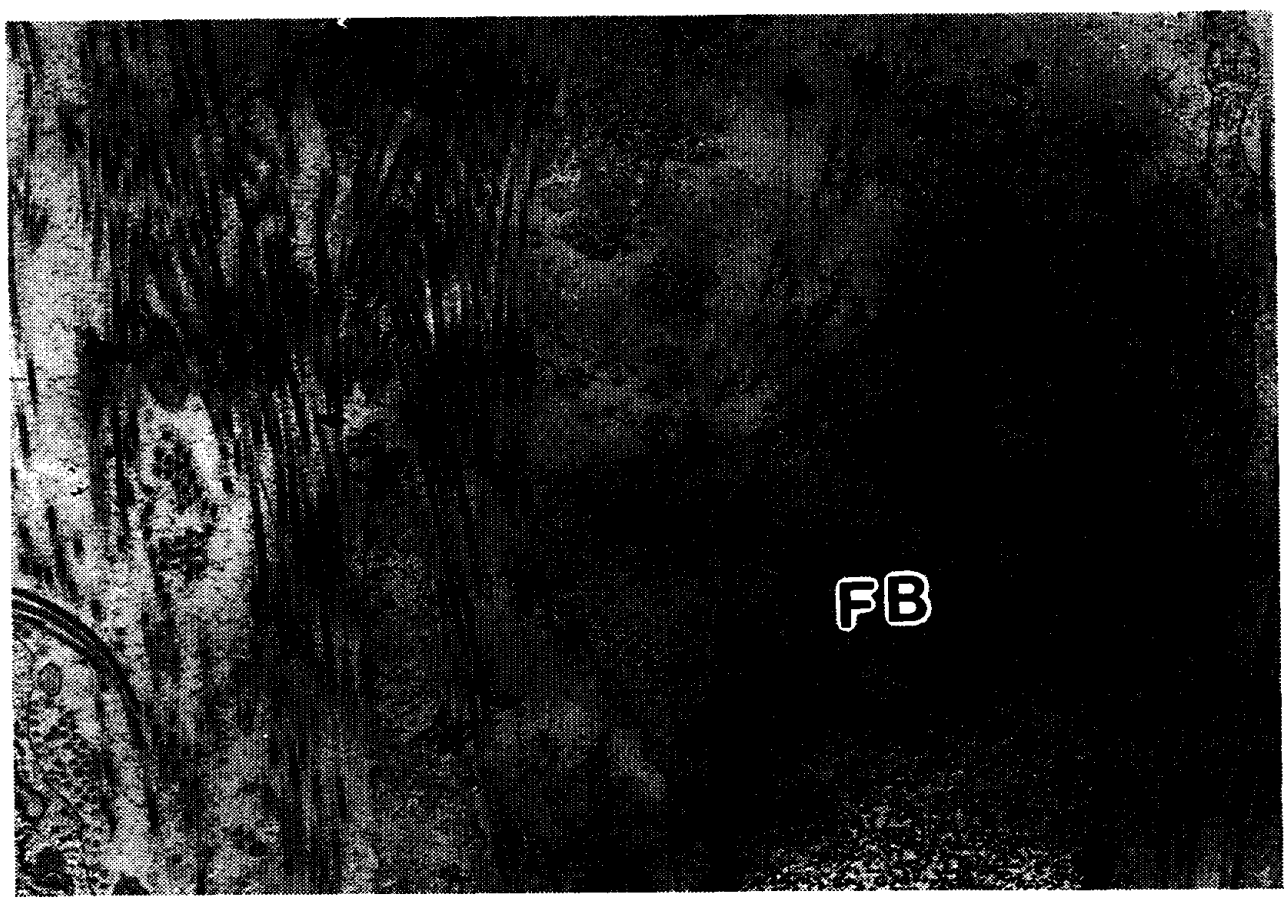

Fig. 48 On the 6th month Control group Periodontal ligament FB : Fibroblast $\times 6,600$ 
められ，ミトコンドリアも認められる，細胞間隙は広 く, コラーゲン原線維がほとんど認められない（Fig. 54). 切断面直下の米骮神経線維を 観察するとシュワン 細胞膜は二重に認められ髄鞘は一部破壊が認められるも
のの規則正しい凰状構造を呈している所見が認められ， 神経細線維，神経細管，ミトコンドリアが認められる (Fig. 55).

根尖部のセメント牙細胞と菌根膜の線維牙細胞は術後

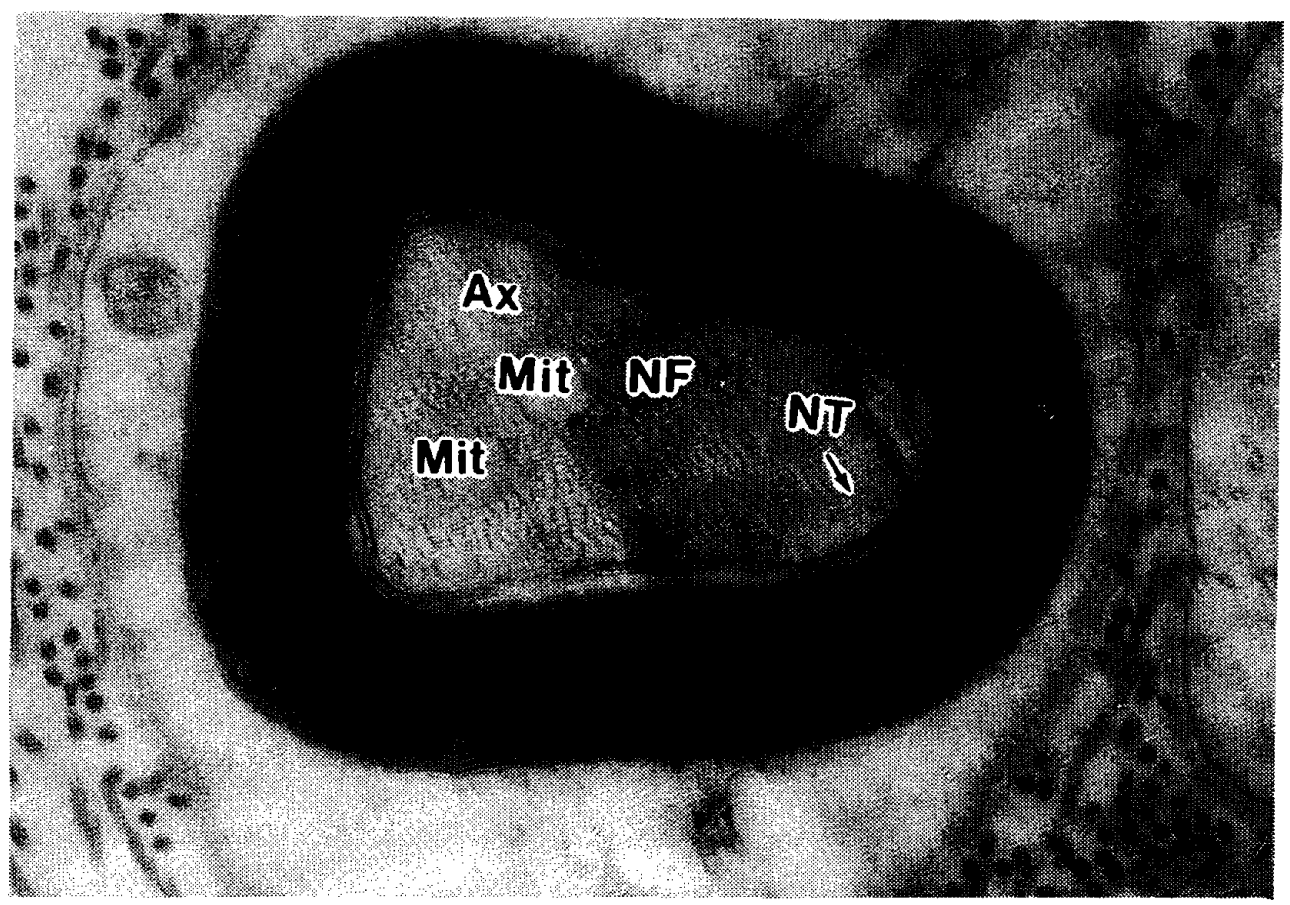

Fig. 49 Control group Nerve fiber NT : Neurotubule NF : Neurofibril Ax : Axon Mit: Mitochondria $\times 8,300$

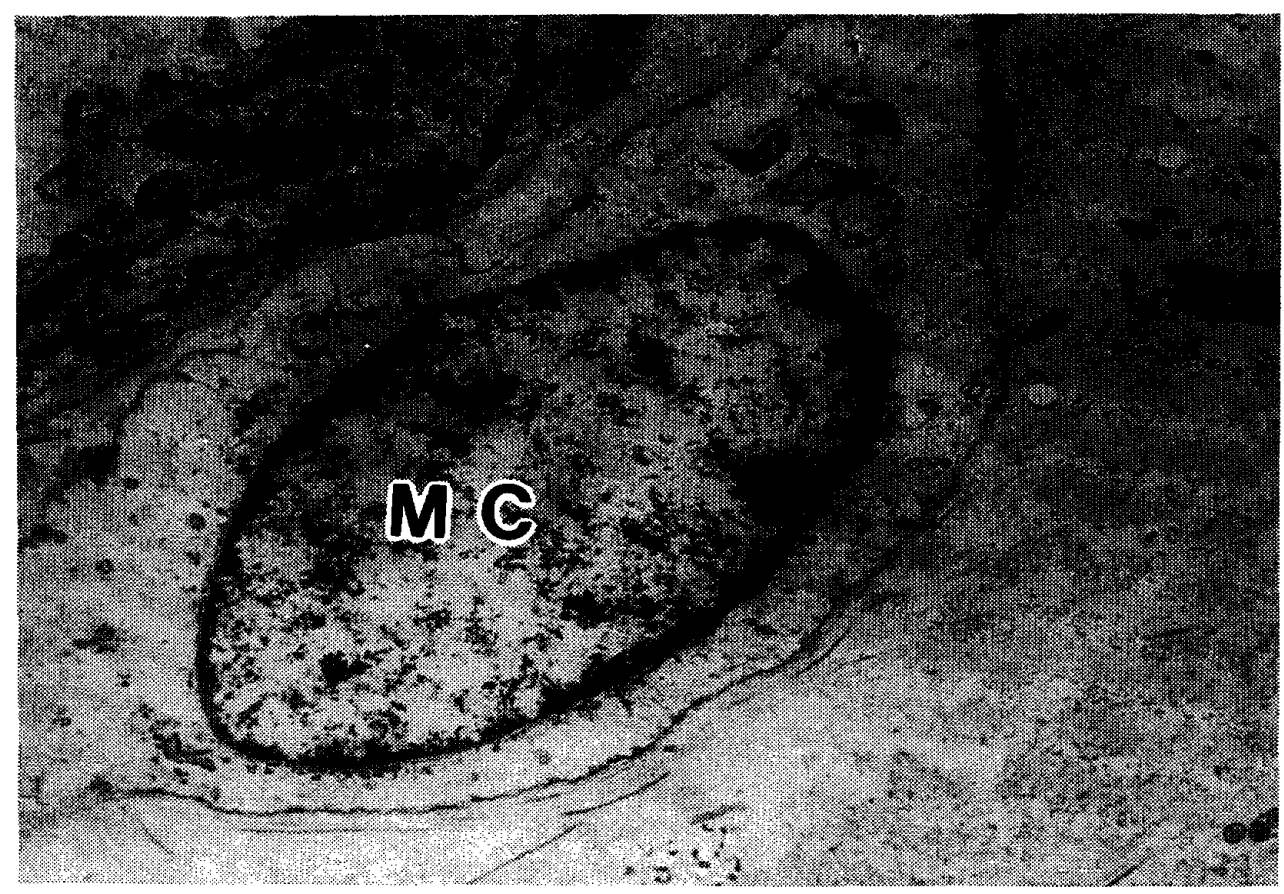

Fig. 50 On the 3rd day

MC : Undifferentiated mesenchymal cell $\times 6,600$ 
3 日と同様の所見を呈している.

術後 2 週間

dentin barrier の形成開始所見を示す直下の象牙牙
細胞様細胞について観察すると，ゆるやかな陥凹を示す 大きな棈円形の核と紐胞質内に核の周囲をとり囲むよう に多数の粗面小胞体とミトコンドリアで占められ，細胞

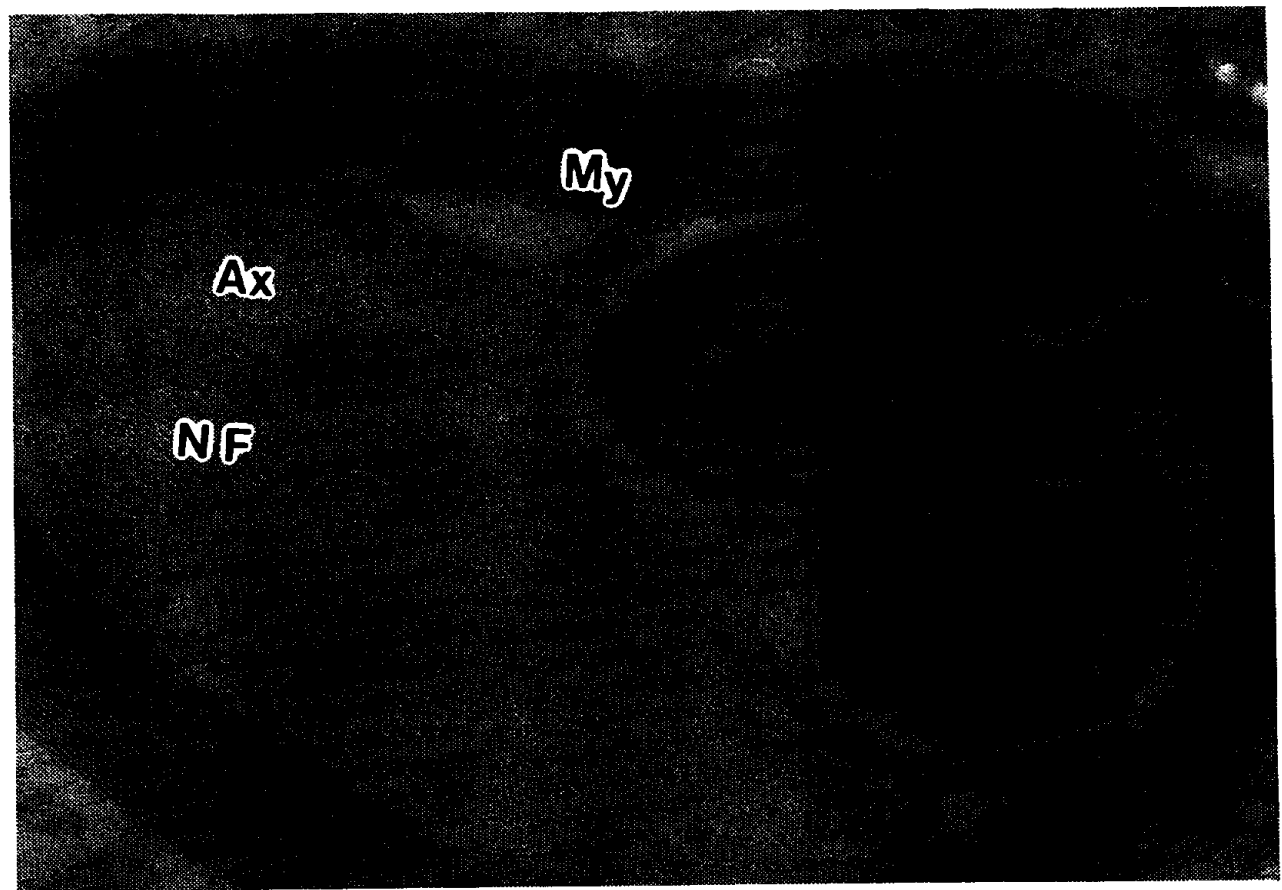

Fig. 51 On the 3rd day Nerve fiber

Ax: Axon My : Myelin sheath

NF : Neurofibril $\times 10,000$

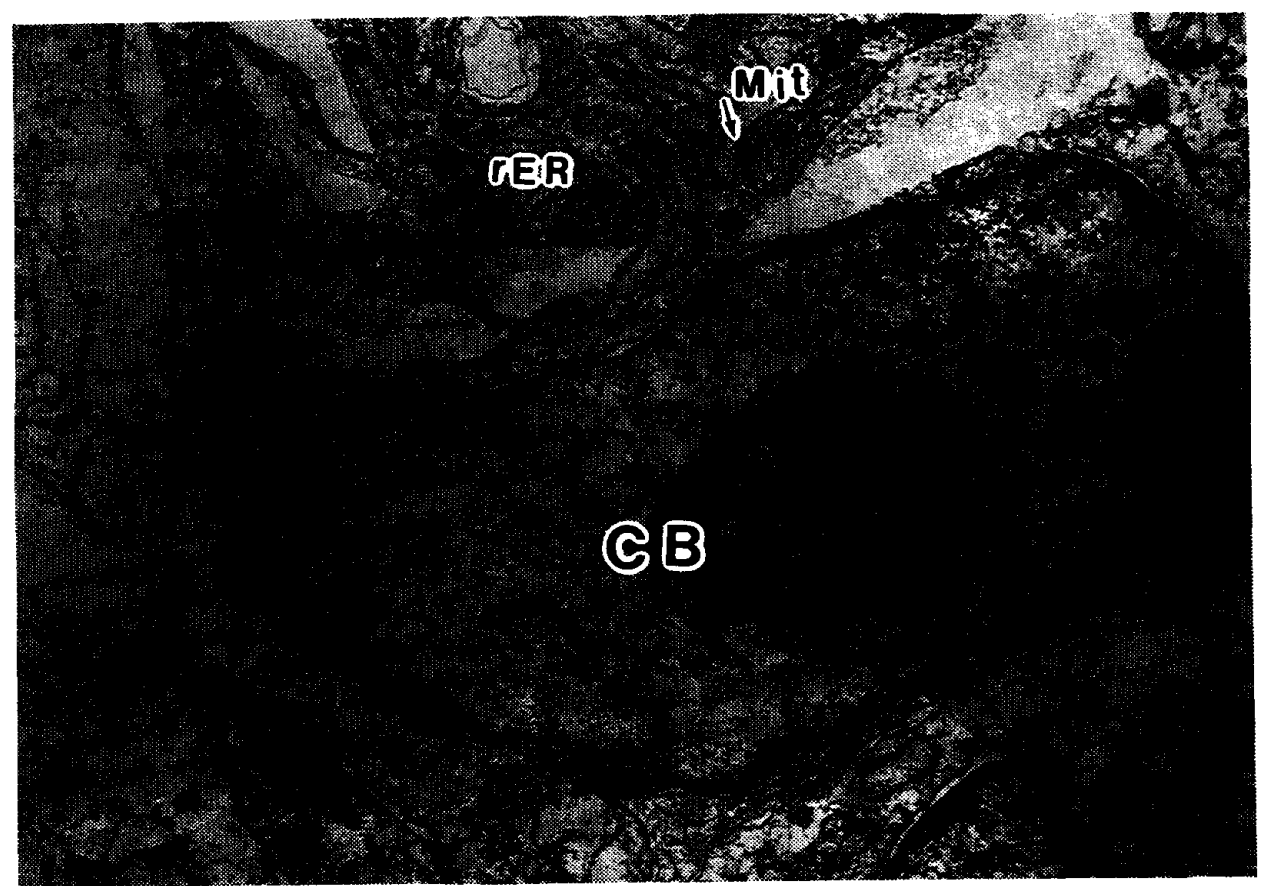

Fig. 52 On the 3rd day

CB : Cementoblast Mit : Mitochondria

rER : rough surfaced endoplasmic recticulum $\times 5,000$ 
間隙は狭く，junctional complex によって結合されて いる (Fig. 56). 歯蹃内神経線維を観察するとシュワン 細胞膜は明瞭に二重で㵦䩪はほとんど規則正しい層状構
造を呈しておう，軸索内にはミトコンドリア，神経細 管，神経細線維が誨められる (Fig. 57).

根尖部においては同時期の対照群と同じ activeなセ

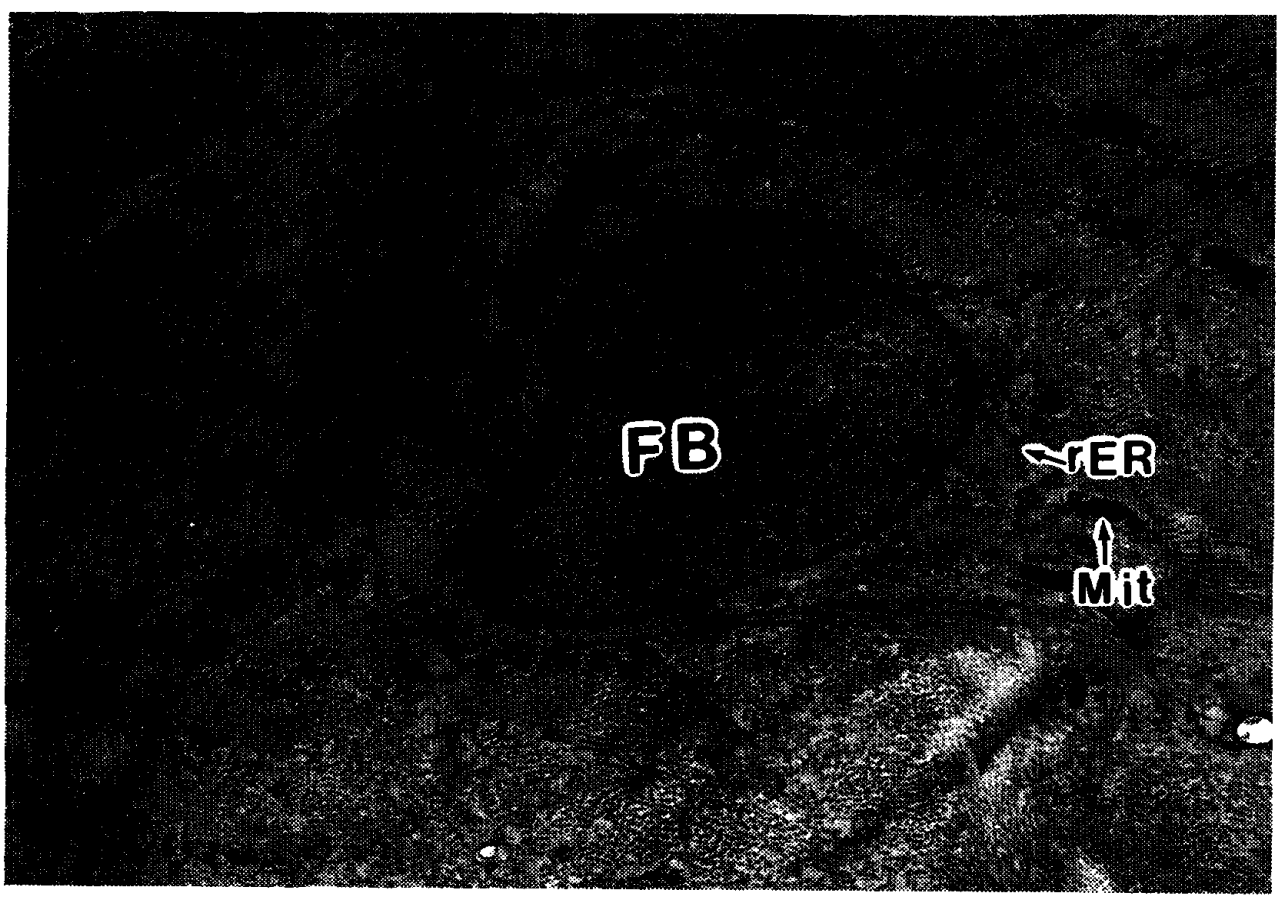

Fig. 53 On the 3rd day Periodontal ligament

FB : Fibroblast Mit: Mitchondria

rER : rough surfaced endoplasmic reticulum $\times 5,000$

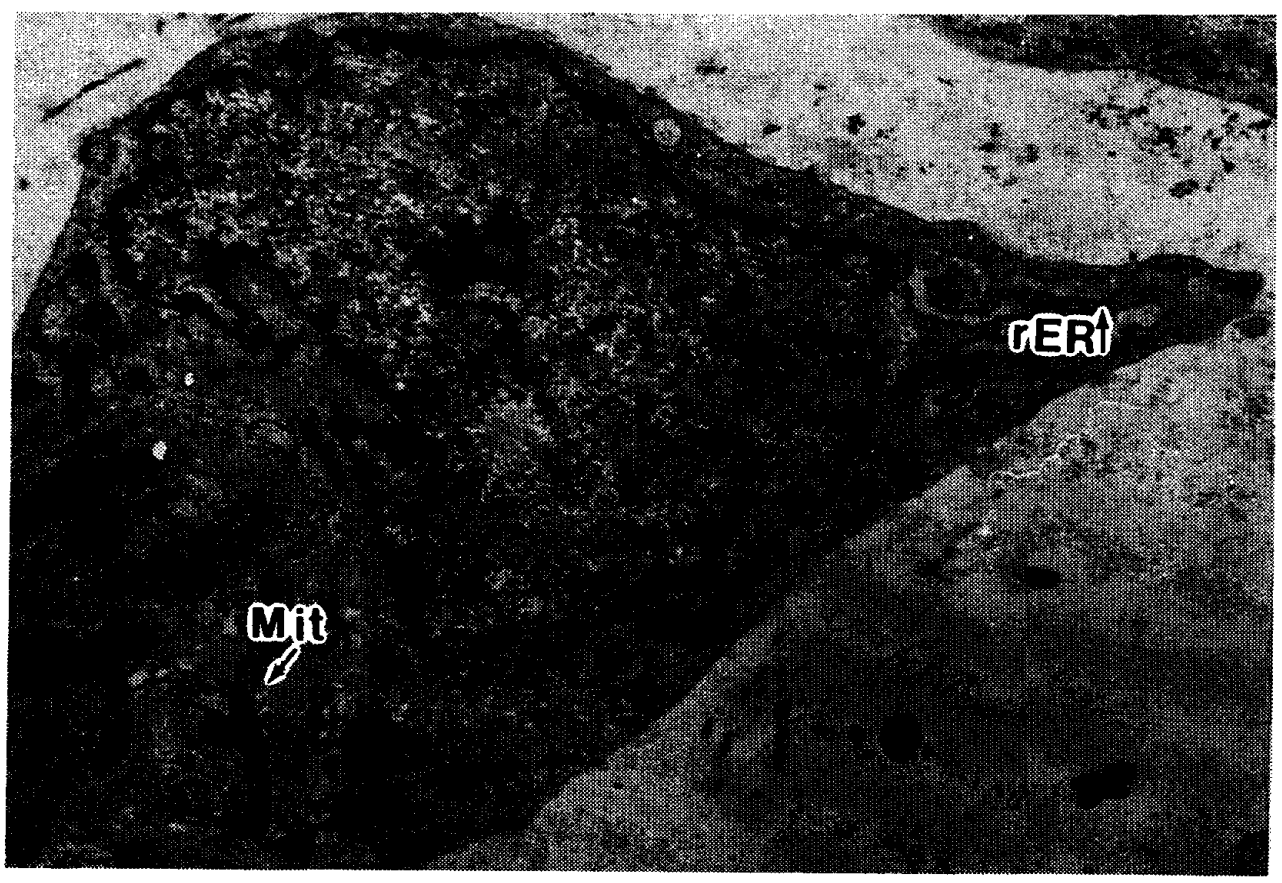

Fig. 54 On the 1st week. Polygonal cell rER : rough surfaced endoplasmic reticulum

Mit : Mitochondria $\times 8,300$ 
メント芽細胞が認められ，大型の楕円形の核をもち細胞 質内には豊富な粗面小胞体とそトコンドリアが喼めら れ，細胞間に多数のコラーゲン原線維が認められる．以
後術後 2 カ月まで同様な所見を呈している．根尖の䨑根 膜の細胞を観察すると，大型の卵円形の核をもち，細胞 質内に多数のミトコンドリアと粗面小胞体が認められ

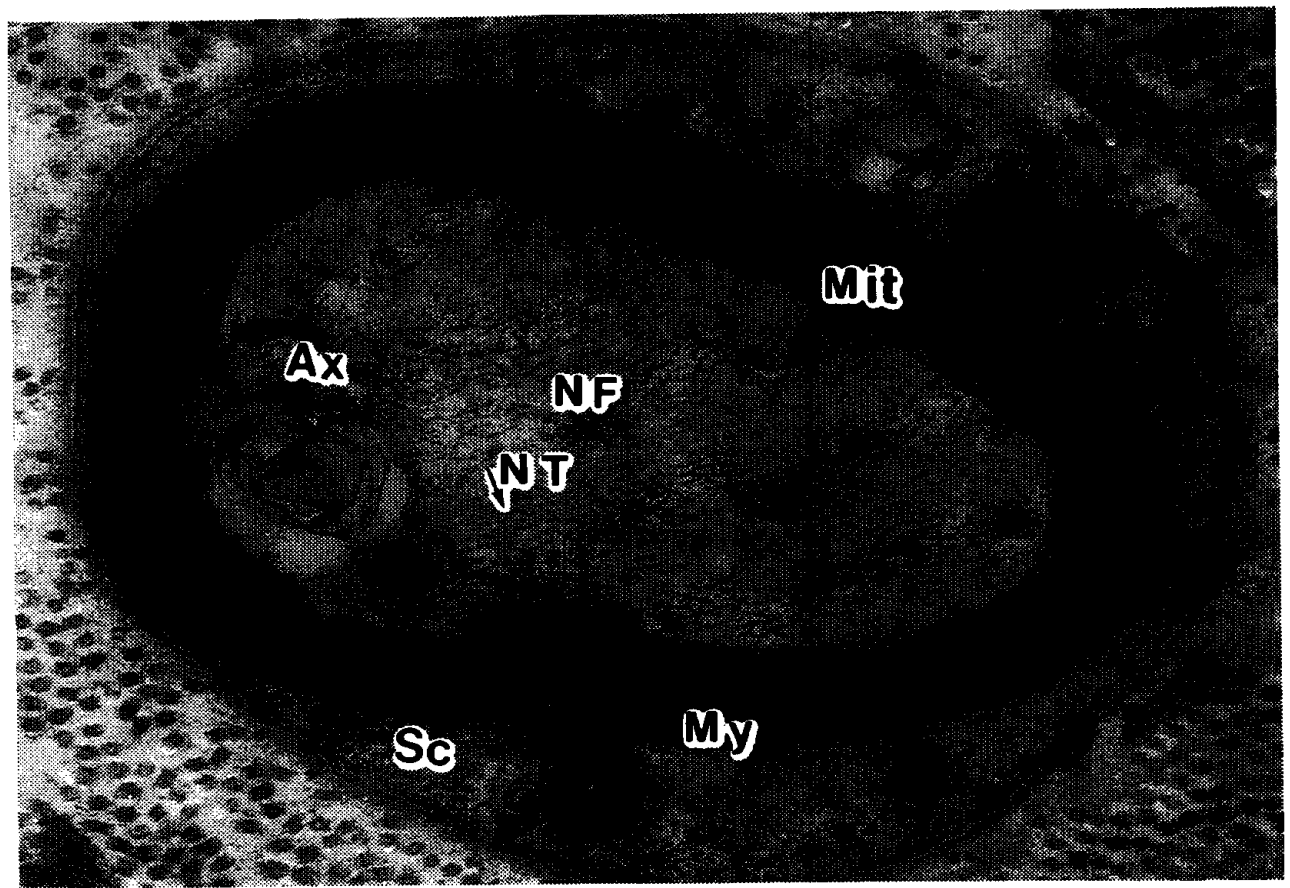

Fig. 55 On the 1st week. Nerve fiber

NF : Neurofibril NT : Neurotubule

Ax: Axon Mit: Mitochondria

Sc:Schwann cell My: Myelin sheath $\times 8,300$

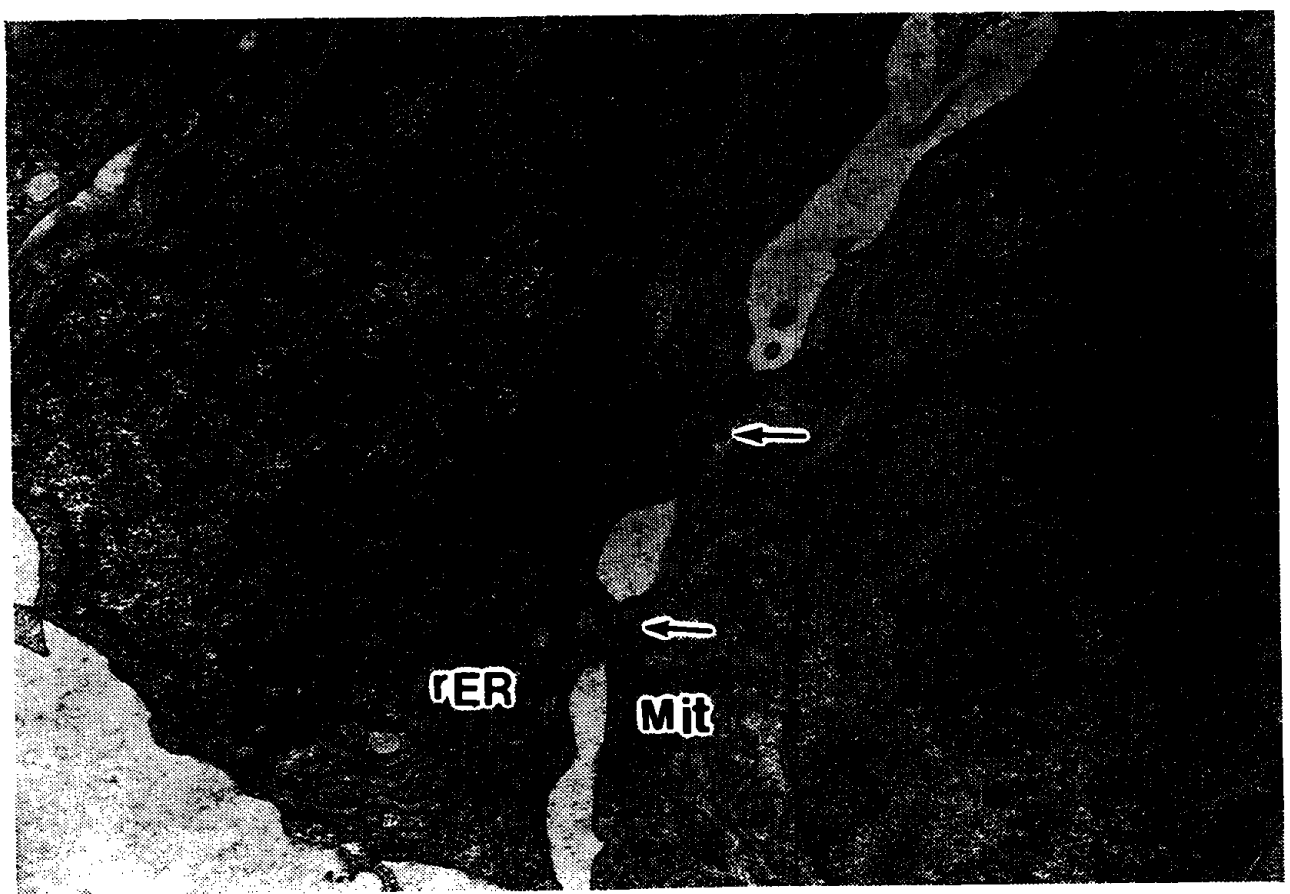

Fig. 56 On the 2nd week Odontoblast-like cell rER : rough surfaced endoplasmic reticulum Mit: Mitchondria $\uparrow:$ junctional complex $\times 8,300$ 
る．その中に大型の卵円形の核をもちその周囲に張原線 維が認められる細胞が認められる．その細胞質内にミト コンドリアが存在するが粗面小胞体は少なくリボゾーム
が多数認められ，マラッセの残存上皮細胞と考えられ る. 歯根膜の細胞を観察すると以後 2 カ月まで同様の所 見を呈している（Fig. 58）。

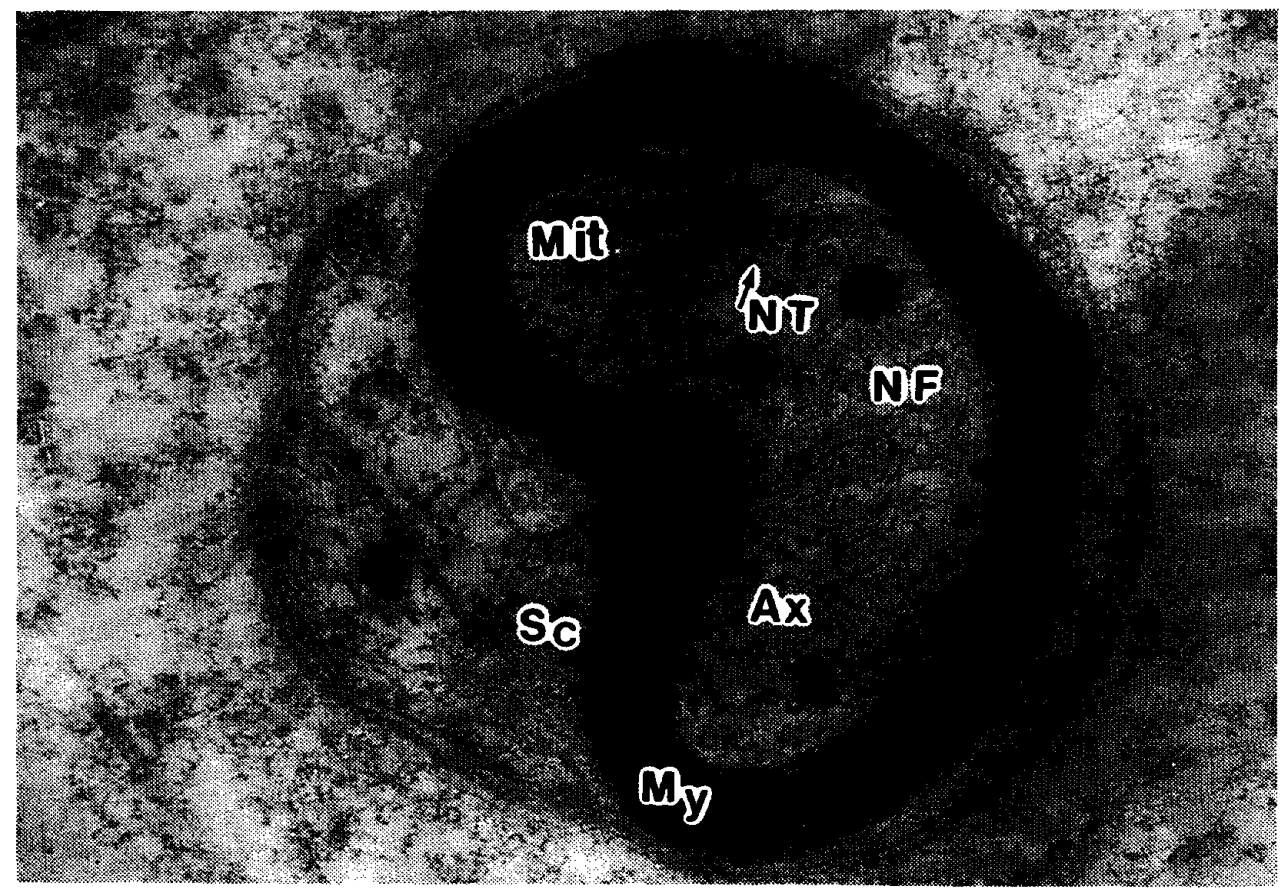

Fig. 57 On the 2nd week. Nerve fiber NF : Neurofibril NT : Neurotubule Ax: Axon Mit : Mitochondria Sc: Schwann cell My: Myelin sheath $\times 8,300$

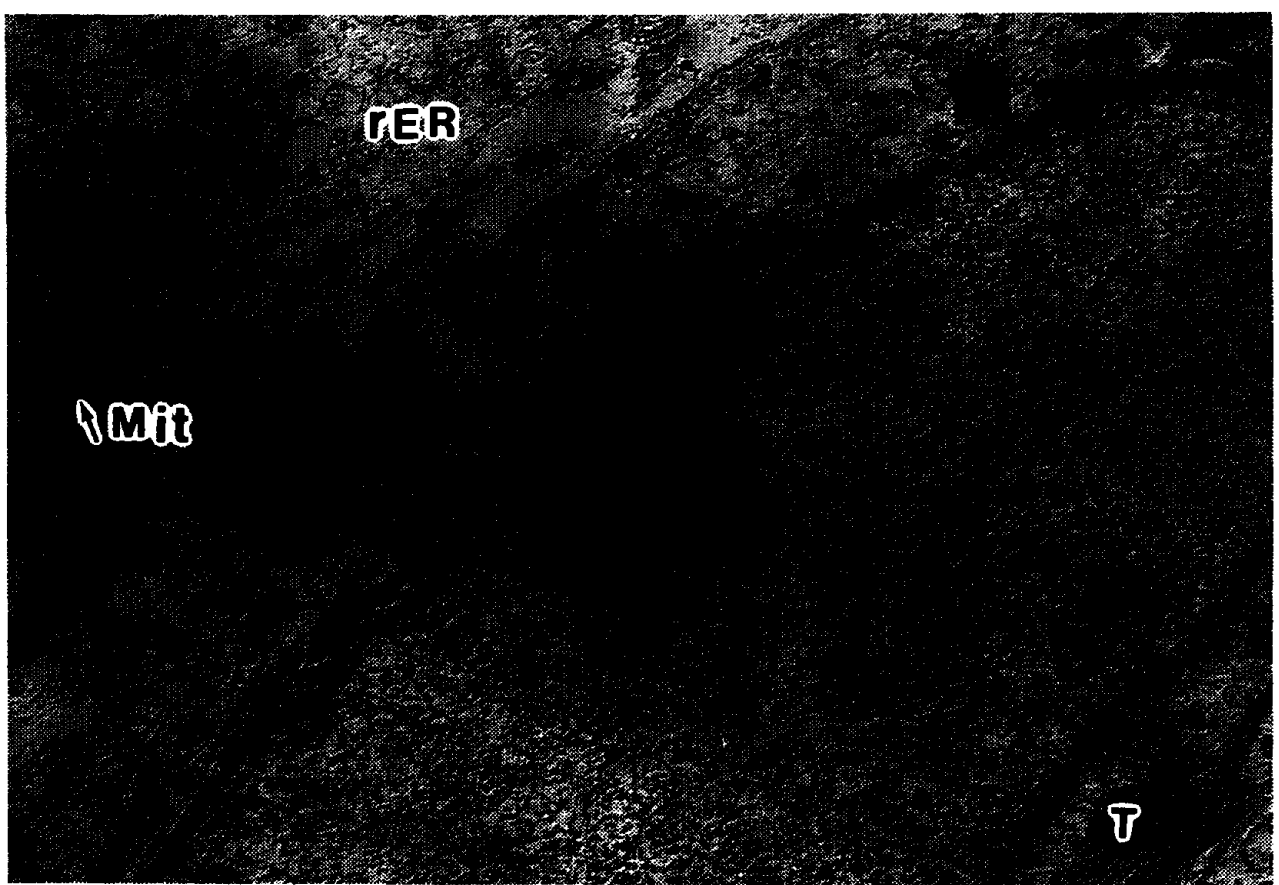

Fig. 58 On the 2nd week Periodontal ligament Mit : Mitochondria T:Tonofilament rER : rough surfaced endoplasmic reticulum $\times 8,300$ 
術後 1 カ月から 6 力月

術後 1 カ月〜 6 力月の dentin barrier の直下の象牙 芽細胞を観察すると卵円形の核をもち，多数の粗面小胞
体，ミトコンドリアなど細胞小器官が偏在し，細胞間隙 は比較的狭い (Fig. 59) . 歯根象牙質の象牙芽細胞を観 察すると, dentin barrier の象牙芽細胞と同様な所見

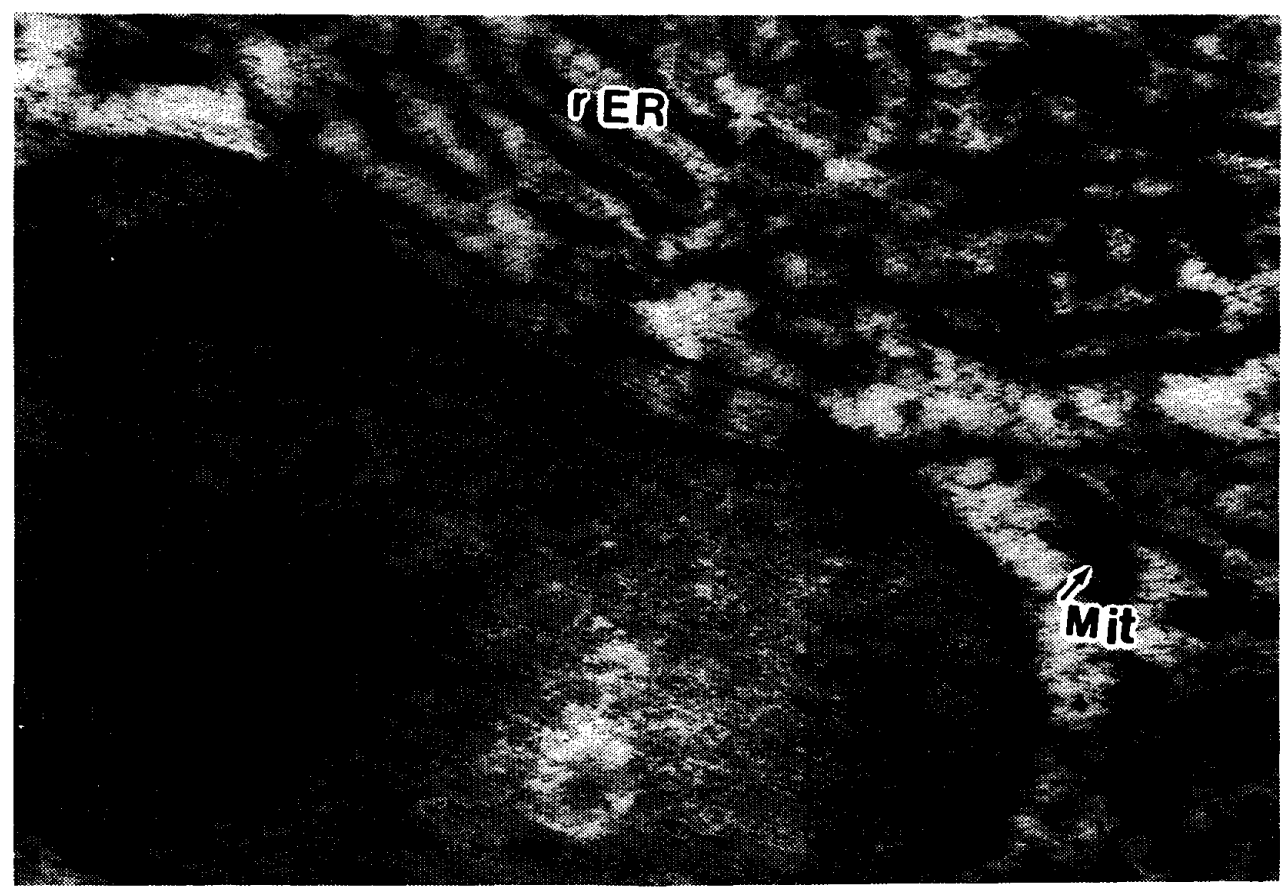

Fig. 59 On the 1st month Odontoblast under dentin barrier rER : rough surfaced endoplasmic reticulum Mit : Mitochondria $\times 8,300$

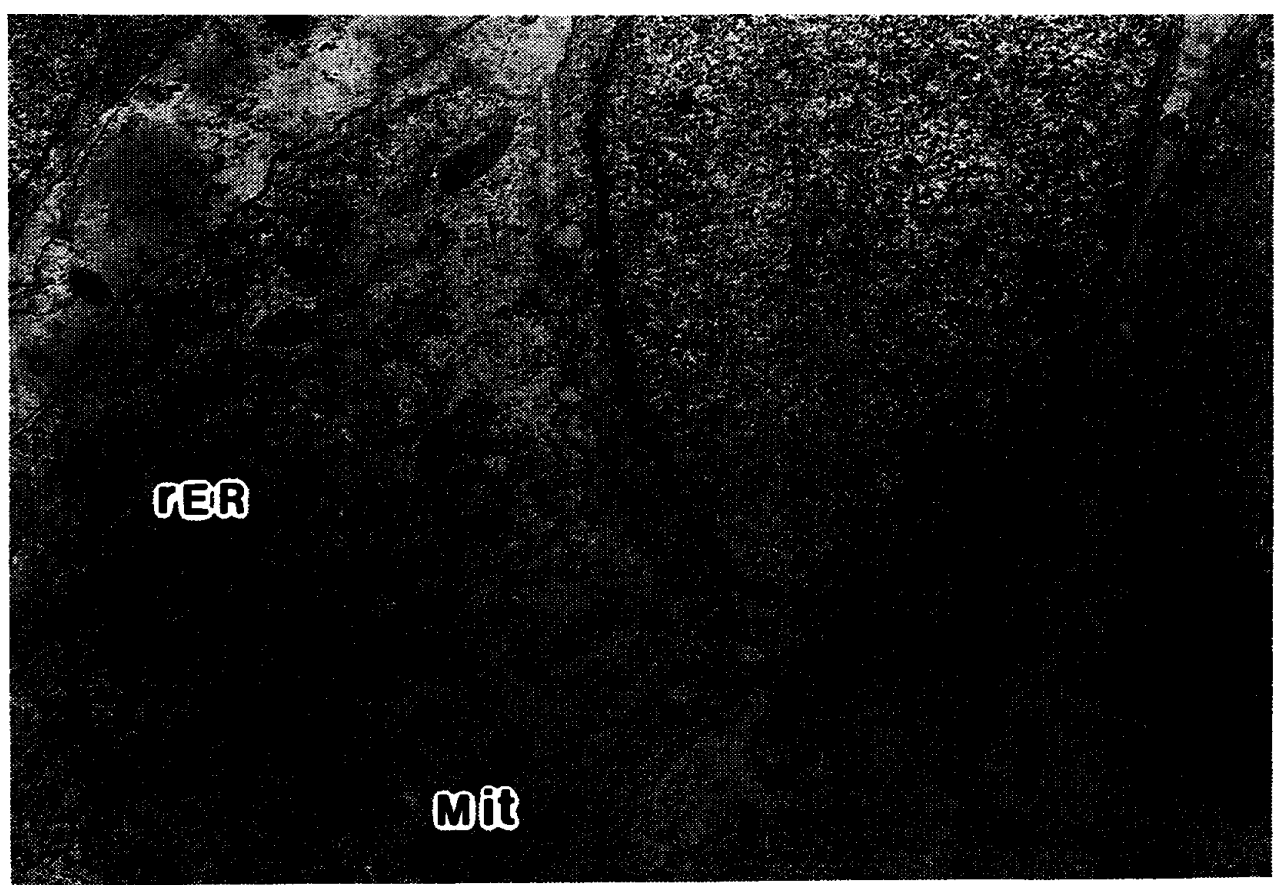

Fig. 60 On the 1th month Odontoblast of root dentin rER : rough surfaced endoplasmic reticulum Mit: Mitochondria $\times 8,300$ 
を呈し，クロマチンに乏しい卵円形の大きな核と細胞質 内には細胞の象牙質側に多数の粗面小胞体，ミトコンド リアなど 細胞小器官が偏在し, 細胞間腺は比較的狭い (Fig. 60).
術後 1 カ月から 6 カ月に至るまで, 神経線維の微細構 造は同様な所見を呈していて，シュワン細胞膜は二重に 認められ，軸索を含み髄鞘のミエリン部は規則正しい層 状構造を軸索には神経細線維, 神経細管が認められる

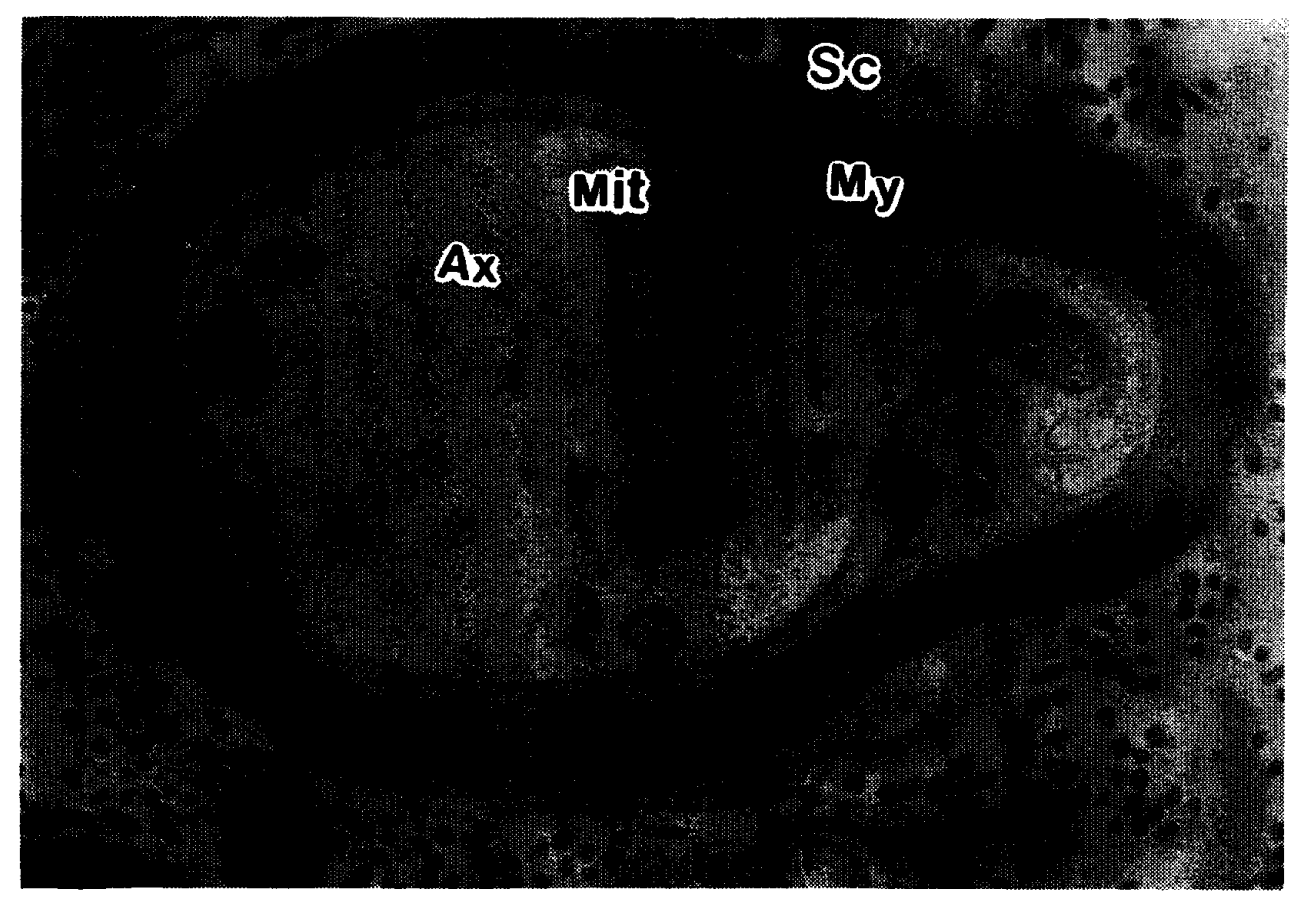

Fig. 61 On the 1st month Nerve fiber Ax: Axon Mit : Mitochondria My: Myelin sheath Sc: Schwann cell $\times 8,300$

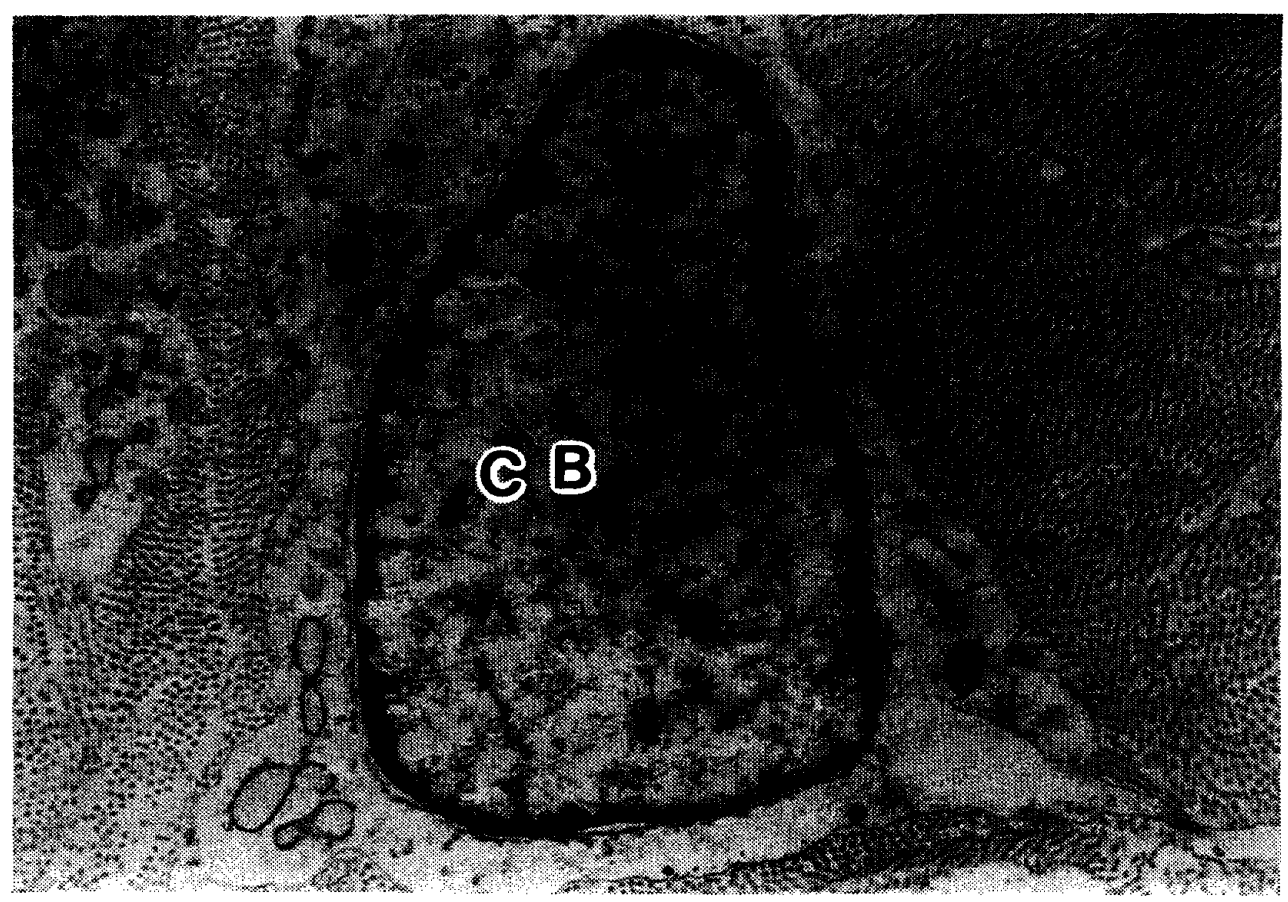

Fig. 62 On the 6th month $\mathrm{CB}:$ Cementoblast $\times 6,600$ 
(Fig. 61).

根尖部のセメント芽細胞を観察すると術後 1 カ月から 2 カ月までは, 対照群と同様の所見を呈し, 大型の棈円 形の核をもち細胞質内に豊富な粗面小胞体，ミトコンド リアが認められる。しかし術後 6 力月目に至ると，対照
群と同様にセメント質表面にクロマチンの豊富な棈円形 の核をもち細胞質内にわずかな粗面小胞体が認められセ メント質に細胞質突起を出し，いわゆる resting cell の状態を呈する細胞が多く（Fig. 62），また，セメント 質中に細胞質内にライソゾームと少数の粗面小胞体とミ

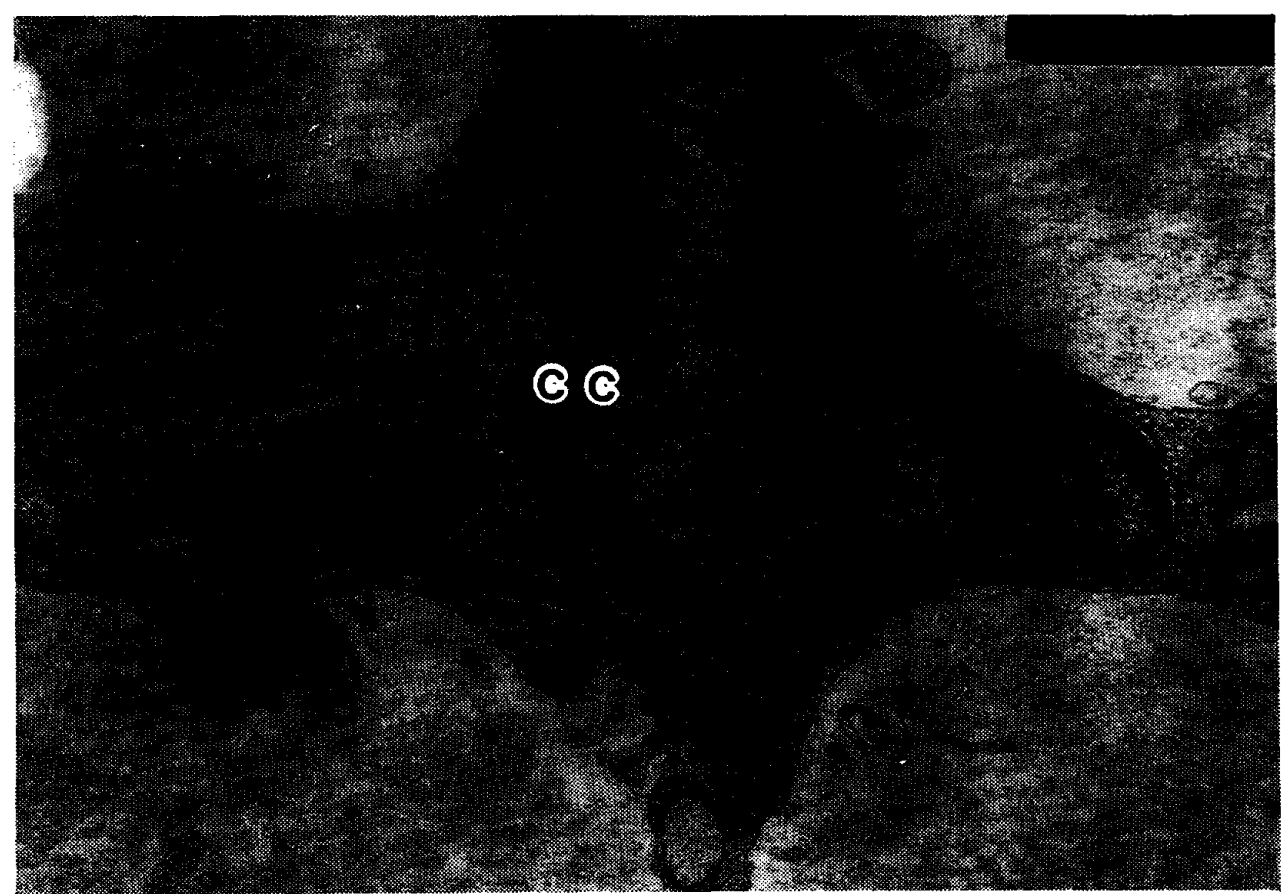

Fig. 63 On the 6th month

$\mathrm{CC}:$ Cementocyte $\times 6,600$

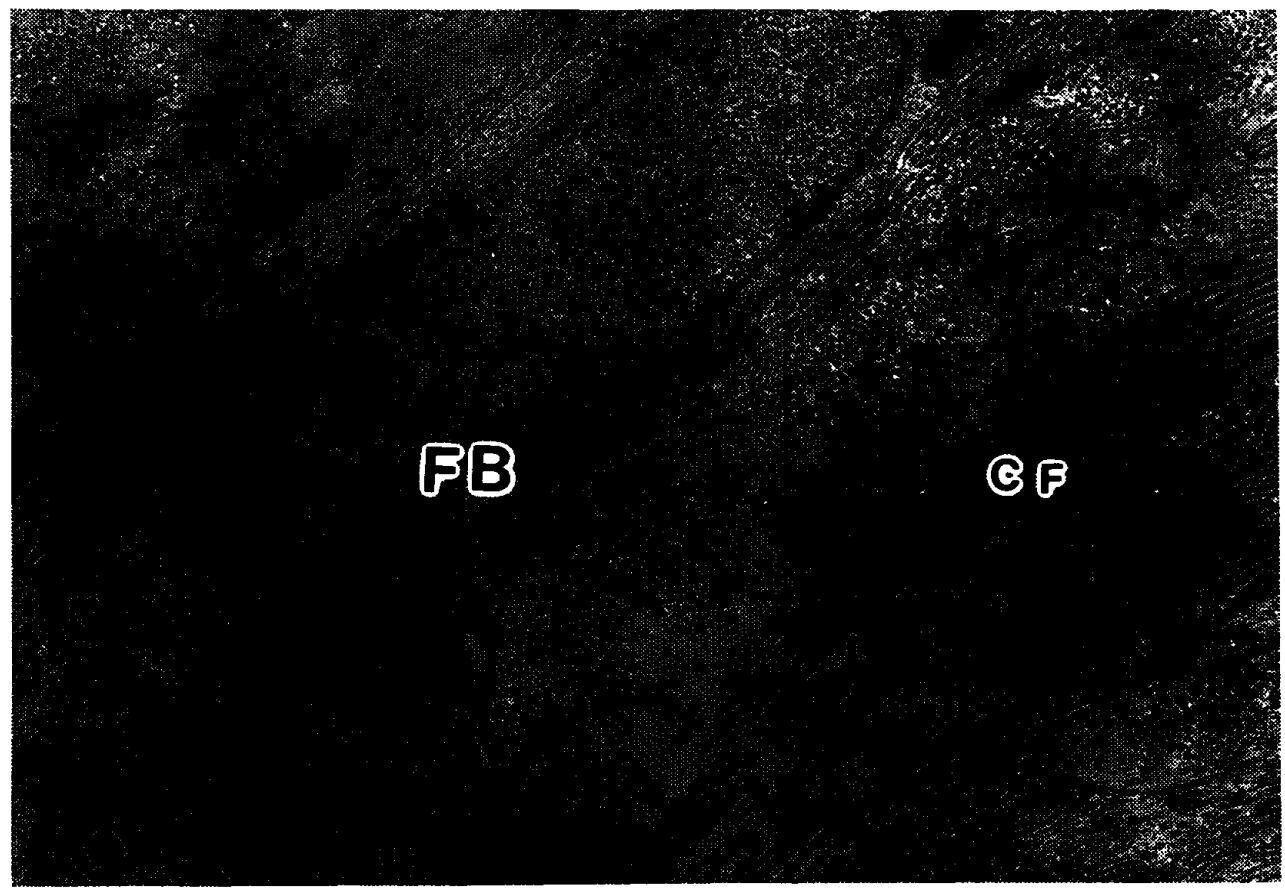

Fig. 64 On the 6th month

FB : Fibroblast CF : Collagen fibril $\times 6,600$ 


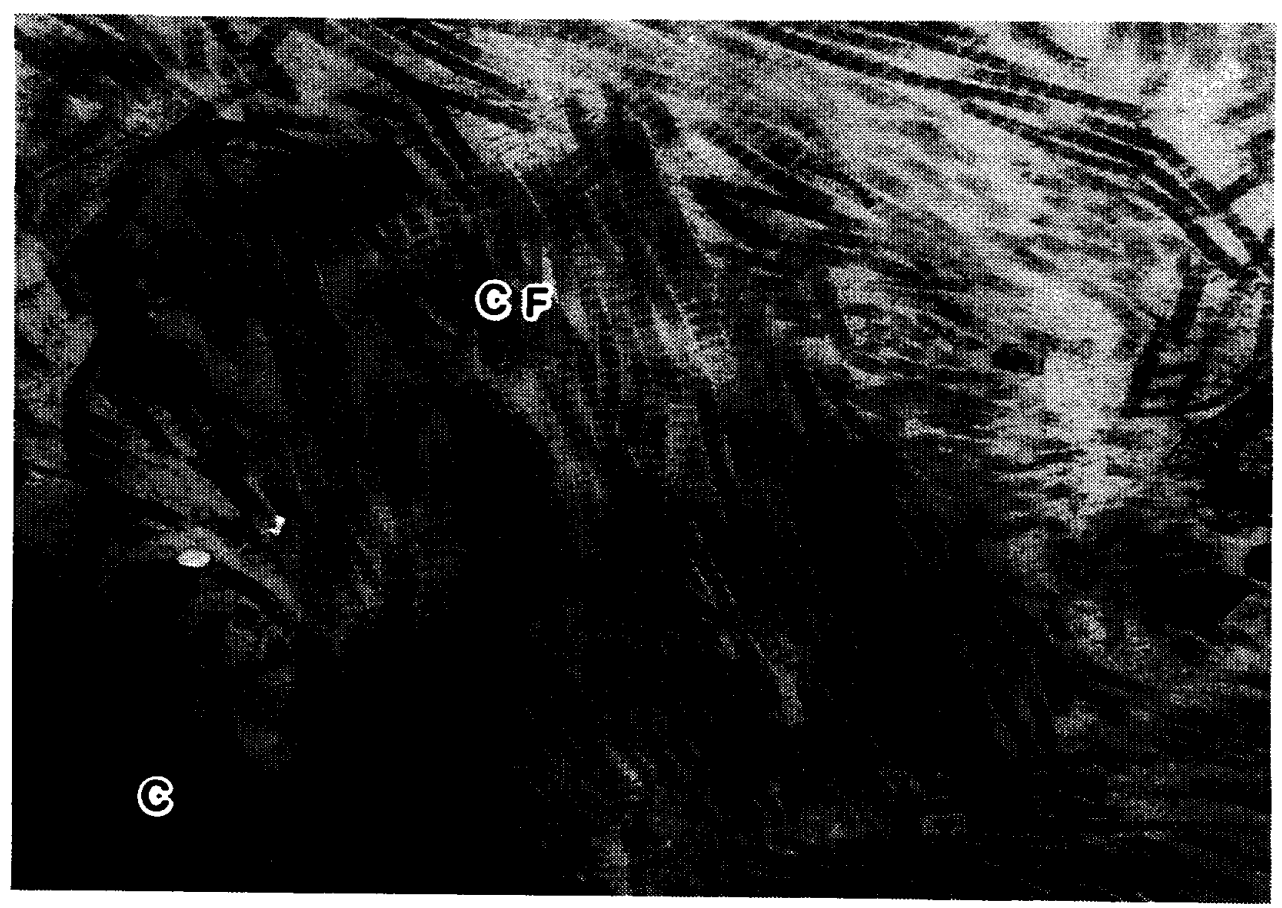

Fig. 65 On the 6 th month $\mathrm{CF}$ : Collagen fibril $\mathrm{C}:$ Cementum $\times 10,000$

トコンドリアをもち細胞小器官にそしいセメント細胞が 認められる (Fig. 63).

歯根膜の線維牙細胞を観察すると術後 1 力月から 2 力 月までは楕円形の核をもち細胞質に粗面小胞体，ミトコ ンドリアが認められ，細胞間に多数のコラーゲン原線維 が諗められるが術後 6 力月になると大型の核をもつが， 細胞質内に粗面小胞体，乏トコンドリアは乏しくなり， 周囲にはコラーゲン原線維束が多数認められるようにな る (Fig . 64).

セメント質表面を強拡大で観察すると，セメント質に コラーゲン原線維束がほほ直角に封入して Sharpey 線 維束となって終止している. Sharpey 線維束はコラー ゲン原線維の周期構造と同椂の編の周期棈造を呈してい る (Fig. 65).

\section{総括ならびに考察}

根末完成永久雪の雪䯣処置に関する研究は多く, 本教 室でも木村 $(1973)^{11}$ ，中村 $(1977)^{21}$ ，神内 $(1985)^{31}$ ， 中村 $(1987)^{4}$ 'が A pexogenesis に関する報告を行い， 品川 $(1980)^{91}$, 鬼塚 $(1986)^{51}$ ，長谷川 $(1986)^{6)}$ は Apexification に関する報告を行っている．根部歯髄の 一部に炎症が波及している根未完成永久雪は蒾質が薄 く，根尖が開いていることから，できるだけ歯髄を保存 することによって，画根の発育，根尖閉鎖を期待しなけ
ればいずれ，歯牙の破折の可能性が高くなり曾牙の保存 が難しい.しかし，根管中間位匊髄切断後の治瘉に及ぼ す研究は町田 $(1960)^{10}$, 山田 $(1970)^{11}$ 'の報告がある 程度で，根未完成永久雪に関しては，ほとんどみられな W.

以下，根未完成永久宩の根管中間位歯髄切断後の創傷 治痗ならびに dentin barrier の形成, 歯髄内神経線維 の動態，雨根の発育，根尖開鎖について著者の研究と過 去の報告を参考に考察する。

近年, pulpotomy に用いる覆㕼浏としては, 主に水 酸化カルシウム製剤 (Calvital, Dycal) グアヤコー ルフォルムアルデヒドの縮合物 (FR) が用いられてい る.今回の実験では，水酸化カルシウム製剂を用いた。 pulpotomy は歯髄充血や急性一部性漿液性歯髄炎など

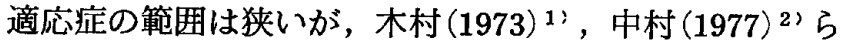
の研究によると, pulpotomy 後, 曾根の発育, 根尖閉 鎖が未好置歯と同様に認められることを実証している. また暽科材料としての安全性と有効性に関しても FDI (国際柬科連盟) ${ }^{12}$ )，ADA (米国歯科医師会) ${ }^{13}$ )，ISO (国際標準化機構) ${ }^{14}$ も生物学的立場を評価している.

I . 霜髄の創傷治痹ならびに dentin barrier の形成

幼若犬の根未完成歯に生活歯髄切断を施した例では木 村 $(1973)^{11}$ は術後 3 日目に買死組織と接した歯骾には 紡錘形細胞の出現と膠原線維の増加を伴った石灰化組織 
と, 新生 dentin barrier の形成開始の様相を呈し, 不 整な象牙芽細胞の出現を認め, 同心゙く中村 $(1977)^{2}$ も 同様な所見を認めている.

本研究においては切断面には分界層の出現が認めら れ，歯髄には血管の拡張，充血ならびに好中球を中心と する炎症性細胞浸潤がみられ，出血栄周囲を線維芽細胞 がとり囲んでいた，木村 (1973) ')，中村 $(1977)^{21}$ らの 創傷治瘾に比べ劣っている.このことは切断部位による 影響と思われる。

切断面直下の炎症層付近の細胞を透過電顕的に観察す ると，成犬の永久歯を用いた pulpotomy に関して，東 (1981) ${ }^{15)}$ は紡䥀形ないし，多角形の細胞を認めており， 細胞小器官が発達していると述べておう，市川（1976） 16) は同じく成犬の永久菌を用いた実験で術後 5 日経過 例で，壊死層直下に比較的核の占める割合の大きい多角 形ないし棈円形の大型の細胞である未分化間葉細胞を認 めており，切断面の新生骨样象牙芽細胞及び，新生象牙 芽細胞は歯髄細胞由来であると述べている．山村 (1985) 17) は歯檤細胞は未分化間葉細胞に脱分化し, カルシウ ムや壊死物質や象牙質削片の残存などの誘導因子によっ て，象牙芽細胞に再分化すると述べている．Fitzgerald (1979) ${ }^{18}$ )によれば，線維芽細胞が活発に増殖し，細胞 の一部が骨または象牙質産生細胞に分化すると述へてい る.

本研究においては，壊死風直下に增殖する細胞は歯髄 細胞の消失した部位で認められ，その部の細胞は，細胞 小器官に乏しく，楕円形の核をもつ細胞が認められるた め，未分化問葉細胞と思われる。

木村 $(1973)^{11}$ は術後 5 日目に新生 dentin barrier の形成をみており，術後 7 日目になると一定の幅を保っ た dentin barrier の形成をみている. 中村 $(1977)^{2)}$ も同様に新生 dentin barrier の形成を認めている.

本研究においても術後 1 週間では分界層直下に，有機 質の形成所見が認められ，石灰化䒽形成開始所見も認め られ，有機質形成直下の䨑䯣および下方の歯㖪内には好 中球を主体とし，軽度の炎症性細胞浸潤が認められるが 限局している. 本研究において dentin barrier の形成 がいまだ認められないのは, 根管中間位で歯髄を切断す るととと，そのために覆髄剤の貼布も難しいという実験 の難易さによると思われる .

術後 7 日の壊死風直下で増殖する細胞を透過電顕的に 観ると, 市川 $\left.(1976)^{16}\right)^{16}$ は術後 7 日に壊死層直下の増殖 細胞は比較的凹凸が著明で，核膜に著明に heterochromatin が集積し，細胞は核をとりまくょうに粗面小胞
体が豊富に存在し，ミトコンドリアも増加しているが， 隣接細胞との接触はみられなく, 細胞間陌が広いと述べ ている. 東 (1981) ${ }^{15)}$ は術後 7 日に壊死層下に密に配列 した梨状の細胞は，外形の不規則な核内にしばしば 1， 2 個の大きな核小体を有し，細胞質には発達した粗面小 胞体を有し, 細胞質には発達した粗面小胞体や小腔を伴 うゴルジ装置, 多数のミトコンドリアが観察され, ト一 ムス突起も形成途上にあるなど象牙芽細胞への移行像を 思わせる所見も認められると述べている。

本研究では比較的核の占める割合の大きい多角形の細 胞が認められるが細胞間隙は広く，周囲にコラーゲン原 線維はほとんど認められないことから，いまだ象牙芽細 胞様細胞の形態をとって抢らず，その前駆体であるてと が考えられる。

術後 2 週間に至ると木村 (1973) ${ }^{1)}$ ，中村 $(1977)^{2)}$ ら やA pexogenesis 汇関する神内 (1985) ${ }^{3}$ 'の研究では, 歯㖪内には出血坚, 炎症性細胞浸潤は殆んぞ認められな いと述べているが，本研究では炎症が限局性にみられ， 他の Apexogenesis の報告に比べ，創傷治瘾が遅延し ているが，幼若犬の根未完成永久歯を用いて FC を応用 した Apexogenesis に関する中村 $(1987)^{4 \prime}$ の報告で は, 切断面直下の歯髄内に軽度の出血之硝子様化が認め られ，創傷治瘉は同様に遅れている。

術後 2 週間の dentin barrier に接した歯髄を透過電 顕で観察すると市川（1976） ${ }^{16)}$ は，歯冠側には骨様象牙 質が形成され，骨様象牙質の内側に円柱状の新生象牙芽 細胞が存在し, 隣接細胞と tight junction, 及び desmosome で結合していたと述べている。また東（19 81) ${ }^{151}$ は dentin barrier 直下の細胞の象牙芽細胞化を 認めている。

本研究では核が霜㗙切断面の反対側に偏在しており, 隣接細胞と junctional complex によって結合してい るものの，まだ核の周囲をとり囲むように粗面小胞体， ミトコンドリアが豊富に認められ，核はゆるやかな陥凹 を示した棈円形の細胞を認め, 象牙芽細胞样細胞を呈し ていると考えられる。

切断面に形成される dentin barrier について観察す ると，本研究では術後 2 週間で dentin barrier の形成 開始所見が認められる.

大野 (1986) ${ }^{19}$ 'は幼犬の乳菌を用いて生活歯䯣切断を 行った研究で, 術後14日で石灭化兩は緅密になり, 辺縁 部で dentin barrier の形成が著明となり，鍍銀染色で 観察すると，辺縁部の dentin barrier ならびに石灰化 柵は，いまだ膠原線維性の粗い基質としてみられ，緻密 
な所と粗となっている所もみられるが, dentin barrier の形成開始所見を呈していると述へている，中村 (19

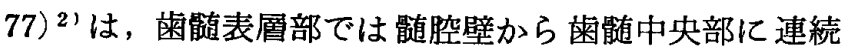
して, dentin barrier ならびに骨梯象牙質の形成がみ られ, dentin barrier は原生象牙質の構造と類似性を もっていると述へている. 本研究では dentin barrier の形成が他の pulpotomy の報告に比べ遅れているもの の，歯随を可能な限り保存し，根尖閉鎖をはかるという 意味において, 順調に dentin barrier の形成は進行し ていると考えられる。

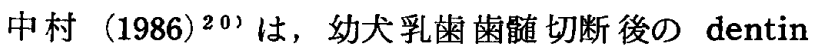
barrier について走查電顕的に観察し, 術後14日では歯 骮側から観察すると，多くの間隙を認め，大小不同の円 形, 類円形の岩石様結晶構造物が認められ, 互いに重な りあったものや㾉合しているものが認められ，その間に 小円状の顆粒状沈着物が集合しているのが認められ，よ り小さな顆粒状物より形成されている粗造な部分が認め られると述べている。

本研究でも切断面を走査電顕で観察すると，雪髄側で は石灰化球樣構造物がみられ，その間に間隙と多数の顆 粒状沈着物も認められ，また苗髄と外界との交通も認め られることから dentin barrier は形成途上であると思 われる。

術後35日目に至ると神内 $(1985)^{3}{ }^{3}$ は生活苗髄内には 出血巣や細胞浸潤は全く認められず, dentin barrier の下方の雬髄は正常像を保っていると述べている．中村 $(1987)^{4}$ ' dentin barrier の直下の茵髄に軽度の出血 と炎症性細胞浸潤と硝子様化を認めると述べている.

本研究では術後 1 カ月目において dentin barrier に 接した歯邻道は正常像を呈しており，FC を応用した Apexogenesis より創傷治瘜は良好と思われる。

dentin barrier の直下の増殖細胞を透過電顕で 観察 すると，市川 (1976) ${ }^{16)}$ は術後21日に新生象牙芽細胞に 類似した細胞が認められると述べており，伊津（1976） 21)は雑種成犬を用いて歯跹切断した術後10１5日に石 灭化層直下に骨様象牙質の形成がみられ，骨様象牙質首 に接する細胞は形態的，機能的に象牙芽細胞に類似した 肥大細胞が認められ，術後20日過ぎに象牙芽細胞に分化 すると述べている．東（1981）15) は術後14日後に，光顕 的, 電顕的に象牙芽細胞を抢もわせる細胞の出現を認め ると述べている。

本研究では術後 1 カ月の dentin barrier の直下の象 牙芽細胞は象牙質の反対側に卵円形の核を偏在させ，豊 富なミトコンドリア，粗面小胞体をもち，歯根象牙質の
象牙芽細胞とほぼ同様な所見を呈するようになり，他の

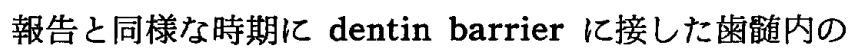
増殖細胞は象牙芽細胞への分化を認めた。

術後 1 カ月目になると, 神内 $(1985)^{3 \prime}$ の報告では辺 縁部加ら歯髄中央部に向って連続して dentin barrier の形成がみられ，柵内方に幼若象牙質が歯根の幼若象牙 質とほほ同等の幅をもって認められ，その内方に象牙芽 細胞が規則正しく配列していると述べている。

本研究では切断面には dentin barrier の形成が認め られる場合と霜髄の固有組織と血管の進入が認められ， dentin barrier の形成が不均一な場合が認められる.

走査電顕で観察すると，中村 $(1986)^{20}{ }^{2}$ は術後35日に 切断面に形成された dentin barrier の形成面に多数の 顆粒状構造物が緻密に集合していて，その部には大小不 同直径 $0.1 \mu \mathrm{m} \sim 5 \mu \mathrm{m}$ 大の小孔が散見され，小孔の周囲 には線維状沈着物が多数みられる，柬㖪側から観察する と，管周象牙質と管間象牙質の区別が不規則な所見を呈 していると述べている。

本研究では術後 1 力月では歯冠側は，緻密さを増し， 粗造面には大小顆粒状構造物が散在し，線維状構造物は 認められないが，雨髄側は中村 $(1986)^{20)}$ と同椂の所見 を呈していて，石灰化は進行していると思われる．

本研究では術後 2 力月目には辺縁部から蔝髄中央部へ 連続して象牙細管構造をもった dentin barrier の形成 がみられ，柵最内方にはエオジンに好染した幼若象牙質 がほぼ一定の幅を保って認められ，歯根象牙質と連続し ている。

神内 (1985) ${ }^{3}$ 'は術後95日に至ると切断面には著しく 厚㶵を增して均等に形成された dentin barrier を認め ている. 中村 $\left.(1987)^{4}\right)^{4}$ は, 術後95日で dentin barrier と曾根象牙質は完全に組織㿎合が行われ，それに伴って 幼若象牙質もほぼその幅を一定にして連続していると述 へ，本研究とほほ同样の所見を呈しているが， dentin barrier の厚径は, 本研究では他の報告に比べて若干薄 弱であった。

術後 2 カ月に至った dentin barrier を走查電顕で観 察すると dentin barrier の縦断面を観察した所見と蒾 葡側より観察した所見は中村 $(1986)^{20}{ }^{2}$ が述べている術 後35日で観察した乳歯の dentin barrier の同部位の所 見とほほ同様であり，本研究では dentin barrier の形 成がわずかに遅延していると考えられる．しかし，中村 $(1986)^{201}$ も象牙細管構造は不均一であると報告してい るととから, dentin barrier は本研究と同様に形成途 上であると考えられる。 
術後 6 力月で本研究では dentin barrier は平滑面を 呈し, 歯根象牙質と癒合し，歯根象牙質と dentin barrier の厚さがほほ均等であった。 dentin barrier を 鍍銀染色で観察すると表層は粗い線維性基質を呈し，内 層は象牙細管構造をもった dentin barrier が厚く形成 しているのが認められる。

中村 $(1987)^{4)}$ は，FC を応用し，術後120日目で dentin barrier は辺縁部から歯髄中央部に連続して象牙 細管構造がみられ，辺縁部では斜走し，中央部の一部を 除いて規則正しい配列を示していると述へていて，本研 究の術後 6 力月目と同様な所見を呈し, 術後 6 力月で十 分に dentin barrier ができると考えられる。

走査電顕で術後 6 カ月の dentin barrier を観察する と, 術後 2 力月では不均一であった象牙細管構造は緻密 で，均一な構造を呈するようになったてとから，十分に 雨髄の被覆保護が可能になったと考えられる.

\section{II . 歯髄内神経線維の動態}

神内 $(1985)^{3 \prime}$ は，術後 3 日で切断部直下の壊死層内 に染色性が低下し，輪郭が不明瞭となった変性神経線維 が観察され, 主として屈曲, 蛇行しながら喑化した形で 残存していると述べている，中村 $(1987)^{4)}$ は術後 3 日 の壊死層には，ほとんぞの神経線維は染色性を低下させ たものや，膨化したまま融解消失したものが多いと述べ ている。

幼犬の乳歯を用いて生活歯骮切断した研究で松山（19 84) ${ }^{22)}$ は，神経線維は壊死層内でほとんぞ顆粒状崩壊や 変性に陥り，消失しつつあるが，とくに歯髄中央部にお いて切断面に向かい膨化しながら融解消失寸前のものも みられると述べている．許（1987） ${ }^{23}$ は幼犬の乳菌を用 いて，FC を応用して Calvital で生活菌軻切断を施し た研究で, 術後 3 日の壊死層直下の炎症性変化のみられ る部に膨化, 肥厚, 屈曲, 断裂, 顆粒状化した変性神経 がみられたと述べている。

本研究では, 切断面の䘚死層内に膨化, 自己融解寸前 の変性神経線維がみられ，直下の歯髄は変性した軸索の 集合が明瞭で，他の報告と同様に強い変性像が認められ た。

許 $(1987)^{23}$ は術後 3 日目の壊死層直下の歯䯙内を透 過電顕で観察し, 哊鞘のミエリン部の破壊が著明で軸索 の微細管の減少を認めると述べている．林（1982） ${ }^{24)}$ は 雑種成犬永久苗を用いた生活菌㖪切断の実験を術後 1 日 目之壊死首内有䯠神経線維の髄鞘の周期構造の乱れが著 明であったと述べている。

本研究における透過電顕的観察では, 髄鞘のミエリン
部の破壊は著明で能鞘の変形に沿って軸索は一部変形が 認められ，軸索と骾豧には間隙が詡められたが，神経細 線維は認められ，神経細管のわずかな诚少が認められ た。

神内 $(1985)^{31}$ は術後 7 日目では壊死層内に変性神経 線維の残存がみられ, 膨化, 顆粒状を呈した変性神経線 維が認められ, 術後 3 日目に正常像が認められなかった 㐘髄内に，神経線維が有機質形成部に向けて上行してい ると述べている．松山 (1984) ${ }^{22}$ は術後 3 日目に石灰化 圆より下方の霜髄内には，大部分神経線維が変性してい るのが, 術後 7 日目には石灰化佣直前まで再生神経線維 がのびていると述べている。

中村 $(1987)^{4}$ 'は広範囲な出血巣に膨化, 顆粒状崩壊 した変性神経線維が一部散見されるが, 出血巣から離れ た部の歯嗹組織内と, 微小神経束, 単一神経線維, 微細 な神経線維が上方に向って伸長していると述べている．

本研究では神内 $(1985)^{3)}$ ，松山 $(1984)^{22}$ の報告ほ

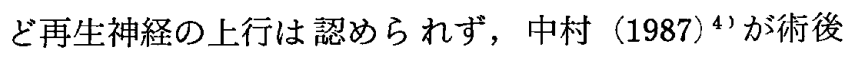
1 週間で述べているように，切断面からやや離れた下方 の歯髄内では神経線維の変性はみることはないが，活発 に再生神経線維は上行していた。

炎症層のある霜髄内神経線維を透過電顕で観察する と, 許 $(1987)^{23}{ }^{3}$ は術後 1 週間目に再生の途中に変性に

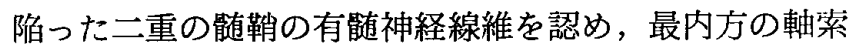
は，ほほ正常像を呈していると述べている．Nathaniel and Peace $(1963)^{24}$ 'はラット脊髄神経線維背根の再生 に関し，髄鞘のミエリン部は破壊したが，基底膜周辺に 有涟化を始めた再生軸索が認められたと述べている。

本研究では透過電顕で髄鞘のミエリン部の破壊も術後 3 日に比べて，かなり少なく一部破壊が認められるもの の，ほとんど規則正しい層状構造を呈し他に変性所見が 認められないととから，歯髄内神経線維の変性は少なく なっていると考えられる。

歯根の発育に伴う神経線維の動態についてみると，根 尖相当部は広く開大し, Hertwig 上皮鞘が著明に認め られ，根尖相当部直下の歯根膜及び槽間中隔，根管中隔 側の Hertwig 上皮鞘の外側雪根膜に神経は集合し，複 雑に分岐, 吻合して神経叢を形成し，㽣䯣内に分布して いく、本研究において柵直下の, 菌䯑道内神経線維の回復 は神内 $(1985)^{3)}$ ，松山 $(1984)^{22}$ に比べ遅延している が, 根尖部の神経線維は一部屈曲, 蛇行した神経線維が みられるものの術後 7 日目の所見としては順調に経過し ていると考えられる。

術後 2 週間目では，神内 $(1985)^{3}{ }^{3}$ は，蒾髄内の変性 
神経線維はほとんど喼められなく，下方から伸びてきた 神経線維を認めるが，石灰化柵には入っていないと述べ ている．松山 $(1984)^{22}$ 'は，乙の時期になると柵に向か う2，3本の神経線維束が活発に走行し，ほとんどの症 例において柵に進入する直前に方向をかえるが，そのま ま終末をむかえるものがみられると述べている。

本研究では単一神経線維, 微細な神経線維が切断面に 向って上行しているが，神内 $(1985)^{3)}$ の報告の上うに 神経束の上行は認められなく，松山 $(1984)^{22}$ のように 上行する神経束が数本認められることもなく，中村（19 87）' の報告之同程度の再生神経線維の伸長が みられ， 通常の Apexogenesis に比べて, 神経線維の再生は遅 延していると思われる.

透過電顕で観察すると，許（1987） ${ }^{23}$ )が述べているよ うに, 内部の䜔鞘のミエリン部の破壊はほとんど認めら れない。

以上のととにより, 術後 2 週間では菌桶内神経線維の 変性はなくなると考えられる。

神内 (1985) $\left.{ }^{3}\right)$ は術後35日目の切断面下方の歯䯣内神 経線維は dentin barrier の下方で向きをかえ，柵に平 行に走行する神経線維を認め，乙れらの神経線維は分枝 を出し，象牙芽細胞に至るものは，わずかに認められる と述へている. 中村 $(1987)^{4)}$ は, 同時期に柵直下の辺 縁部に上行してきた微小神経束，単一神経線維は象牙芽 綀胞下方で終っていると述べている．松山（1984）221は 柵直下の辺縁部から分岐した微細な神経線維が豊富に縦 横と交叉，吻合し，象牙芽細胞内に入るものが垫められ ると述べている．許 $(1987)^{231}$ は，同時期の雬能内に は，神経束から分岐した微細な神経線維の分岐が認めら れるが, 神経叢や象牙芽細胞層付近に進入する自由終末 はほとんど認められないと述べている．

本研究では術後 1 カ月目では中村 $(1987)^{4)}$, 許 (19 87） ${ }^{23}$ ) らの報告と同様に柵に向かう神経線維はその直前 で向きをかえて辺縁に伸びていて，そのまま上方の dentin barrier に向けて上行するものも認められるが, 神内 $(1985)^{3)}$ ，松山 $(1984)^{22}$ 'の報告でみられるよう に，神経叢の形成は認められず，象牙芽細胞風に進入す る神経線維はほとんど認められず, 再生神経線維の伸長 は遅延していると考えられる。

術後 1 力月以降の棶髄内神経線維を透過電顕で観察し ても，本研究では神経線維の変性は認められない．

根尖部セメント質が添加され，分岐根管が形成される

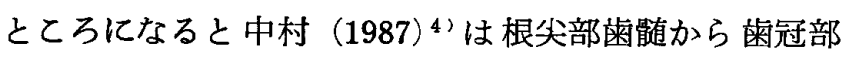
に向って上行する神経線維は歯髄の中央部に位置し，
大，中，小神経束が通過していて，健全な神経線維が走 行していると述べている.

本研究において根尖相当部直下の歯根膜に集合する神 経線維は神経叢を形成しているもの，根管中間位で歯鹃 切断したため，根尖部から曾髄内に進入する直前に変性 に陥る神経線維も散見され，上行する神経線維の数は減

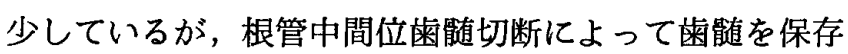
し，歯根象牙質の発育を伸長させる目的においては術後 1 力月目の所見は順調と思われる.

術後 2 力月になると根尖相当部神経叢内にみられた屈 曲, 蛇行, 膨化を呈する変性神経線維は, 雨根が完成期 に入ってくると著しく少なくなる。

本研究では根管内の歯髄中央部を走行する神経線維は 小神経束や単一神経線維が上行する. しかし, 神内 (19 85) 32の報告でみられるような中神経束は認められない．

術後 6 カ月に至ると, セメント細胞を封入した有細胞 セメント質により根尖は閉鎖され，歯根は完成する．神 内 $(1985)^{3}$ は術後95日になると下方の蒾髄から伸びて きた神経束及び単一神経線維は象牙牙細胞に終末分岐を 出して, 辺縁部に達するとさらに分岐を増し，てれらの 分岐は複雑に交錯して神経叢を形成すると述べている。 中村 $(1987)^{4}$ ' は術後120日に歯髄中央部の健康組織から 上行してきた大, 中, 小神経束, 単一神経線維は柵近く の菌髄内に到達すると膨化, 断裂, 顆粒状化を呈し, 椢 直下で変性に陥らず健全な姿を呈したものは象牙芽細胞 に向って分枝を派出しているが辺縁部の象牙芽細胞層に 進入して終止するような遊離終末もほとんど認められな いと述べている。

本研究では術後 6 力月経過しても辺縁部の象牙芽細胞 㬝に終止する神経線維は少なく，神内 $(1985)^{3}{ }^{3}$ の報告 にあるような柵直下に神経叢を認めなかった，歯栺直を根 管中間位で切断したため, 再生神経線維の伸長は遅延し

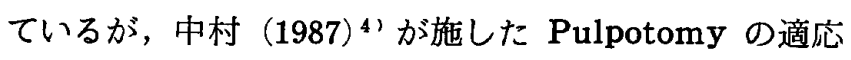
範用を拡大する意味で FC を応用した Apexogenesis の場合より，根管中間位で歯髄を切断した本研究の方が 再生神経の伸長は認められた。

神内 $(1985)^{3 \prime}$ の報告では, 霜根完成期の根尖の菌根 膜の神経叢から側枝を通じて，大，中，小神経束が血管 とともに歯䯣内に進入しているが，本研究では歯髄内に みられる神経束はほとんどが中，小神経束で神経線維の 再生も遅延しているが，柬轲内には炎症は認められない ことから，今回の観察期間は柵直下に神释叢は確認され なかったが，より長期の観察を行った場合，神経軖の形 成がみられると思われる。 


\section{III . 根尖閉鎖}

神内 $(1985)^{31}$ は術後 3 日から 7 日まで, 根尖部は広 く開大し, Hertwig 上皮鞘は著明に認められ, 有細胞 セメント質の添加は認められないと述べており，中村 (1987) 4) 同様な所見が得られ，本研究でも同様な所見 が得られた。

幼若犬の根未完成永久歯は再植後, 透過電顕で観察し た辻 $(1988)^{25}$ の報告では対照群は, 術後 3 日では根尖 部幼若象牙質表風は大きく明瞭な核小体をもつ大型の核 と細胞質内に豊富な粗面小胞体を有するセメント牙細胞 を認めており, 細胞間隙は比較的広く, 間陌中には赤血 球を認めると述べている。

本研究においても実験群, 対照群とも大型の核をもつ 細胞内に豊富な粗面小胞体とミトコンドリアをもつセメ ント牙細胞を誌めている。

神内 $(1985)^{31}$ は術後 2 週間でほとんどの定例でまだ 有細胞セメント質の添加は認められないと述べている が, 中村 $(1987)^{4}$ 'は術後 2 週間で根尖に有細胞セメン 卜質の添加を認めていると述べている.

本研究では Hertwig 上皮鞘は消失し, 有細胞セメン 卜質の添加を認めているが，実験材料の個体差によるの である。

同時期のセメント芽細胞を透過電顕で観察すると辻 $(1988)^{25}$ 'は対照群でセメント質表風で核小体の明瞭な 大きな類円形の核と細胞質に豊富な粗面小胞体とミトコ ンドリアを認め, 活性が高いと報告している. 本研究で も対照群，実験群ともに同椂な active な所見を呈して おり，根管中間位苗䯑道切断は，根尖部のセメント芽細胞 にほとんど影響を与えていない．

術後 1 力月から 2 力月まで神内 $(1985)^{3)}$ ，中村 (19 87) 4) らは，根尖が有細胞セメント質による閉鎖が認め られるようになると報告している．幼若犬の根未完成永 久歯を用いて Apexification を施した品川 $(1980)^{9}$ 'に よるとての時期では根尖部は硬組織の閉鎖は認めていな い之報告しており，幼若犬の根未完成永久菌を用いて， Apexification を施した研究で長谷川 $\left.(1986)^{6}\right)^{6}$ は, 術 後 2 カ月で菲薄なセメント様硬組織の形成を認めると述 べている.

本研究では術後 2 力月までに, 神内 $(1985)^{31}$, 中村 (1987） ${ }^{4)}$ らの報告とほぼ同様の時期に，有細胞セメント 質の添加によって根尖閉鎖が認められ，Apexification に比べより早い時期に根尖閉鎖が認められる.

術後 2 カ月の根尖部に形成されたセメント質を走查電 顕で観察すると, 実験群, 対照群ともにセメント質表面
は，全般にわたって線維成分に富んでおり，石灰化が進 んでいない所見がみられ，まだ根尖部セメント質は石灰 化途上であることがわかる.

この時期の雬根膜をみると木村 $\left.(1988)^{26}\right)$ は，根側で は線維性結合組織から構成され，歯根の完成時にみられ る歯根膜の主線維を示す歯槽縁, 水平方向, 斜走方向を 示す雨根膜線維は配列を不規則にして喼められるが，根 尖部のセメント質と歯槽骨に放射状に進入する歯根膜線 維束の形成は不安定な状態といえると述べている．本研 笢では術後 1 力月目に根尖閉鎖が認められたが，歯牙は 十分な咬合機能をはたしていないため，雨根膜はセメン 卜質から雬槽骨に向って，茵根膜線維が認められるもの の機能的配列は認められない.

この時期の曾根膜の細胞を透過電顕で観察すると，雨 宮 (1983) 27'は線維形成の盛んな部位では, 多数の突起 を有する線維芽細胞が認められ，よく発達した粗面小胞 体をもち，ミトコンドリアが細胞質内に分布していると 述べている。

本研究でも 同様の所見を呈していて, 線維芽 細胞は active な状態にあるといえる。

術後 6 力月に至ると長谷川 $(1986)^{6)}$ は Apexifica tion を施した実験群では根尖に，菲薄なセメント様硬 組織ができるが，十分でなく，8力月に至ると厚いセメ ント質の形成により, 完全に根尖は閉鎖され，側枝様構 造も認められる。根尖部外側面よりセメント質の形成が みられ，根尖部まで連続して厚い硬組織の根尖閉鎖がみ られると述べている．神内 $(1985)^{31}$ は術後 95日で実験 群, 対照群ともに根尖部の有細胞セメント䨘が球状に形 成され，全域にセメント細胞を封入したセメント小腔が 散在し，石灰化が完了していると述べている.

中村 (1987) ${ }^{4}$ も，術後120日で有細胞セメント質の形 成により, 根尖部の閉鎖は，ほほ安定した状態を呈して いると述べている。

本研究では一部にわずかな象牙質の内部吸収がみられ るものの，その部にセメント紐胞を封入したセメント質 の形成がみられ，十分に根尖は閉鎖し，根部菌髄は保存 されている．根管中間位歯髄を切断してもその後の歯根 象牙質は十分厚さを増し，咬合に対して雪根部の強度は 十分増してくると考えられる。

根尖部のセメント質について，鬼冢（1986（5) は Microphotogram で術後 6 力月目の実験群の apical bridgeは，いまだ対照群に比べて低い值を示している が, 術後 8 力月に至ると根尖部セメント質は, 対照群と 実験群は近似の值を示すようになると述べている。 
走查電顕による観察において, 本研究では根尖部には セメント質表面に全体的に平滑面を形成し，小孔を多数 認められる. また小窩も認め, 石灰化小球は密に集合 し，表面は緻密さを增し，石灭化度が高い，

同時期の根尖部を 透過電顕で観察すると，辻（1988） ${ }^{25}$ 1 は対照群の曾根完成期で，セメント質表面に棈円形 の核と細胞質にわずかな細胞小器官をもつセメント牙細 胞が認められ，セメント質中に細胞質突起を出してい て, resting cell の状態を呈しており, セメント小腔内 にセメント細胞が譙められ，紐胞質全体が暗調像を呈し ていて，細胞質内に粗面小胞体，ミトコンドリアがそし く，ライソゾームを認めると報告している．

本研究でも対照群, 実験群ともに根尖部に形成された 有細胞セメント質は，ほぼ対照群と同様であった。

術後 6 力月目の菌根膜を観察すると, 対照群, 実験群 ともに機能的配列を示すようになり，その雨根膜の密度 もほほ同様の所見を呈している. 苗牙の萌出が完了し， 咀嚼機能がはたされるようになり, 畨根膜が安定した状 態になったと考えられる。

この時期の柬根膜を透過電顕で観察した雨宮（1983） 27) の報告では蒾根膜の 線維芽細胞の 細胞質突起が縮小 し, 細胞小器官も減少し, コラーダン原線維束の走行 に，細胞の長軸に一致した形態を示していると述べてい る. 本研究でも術後 6 力月目で同様な所見がみられる. 本研究においては走査電顕で根尖には，円形または楕 円形を示す Sharpey 線維束の横断像がみられ，中心に 丸くなった低い隆起のみられる型が多くみられた。これ は Armitage (1980) ${ }^{28)}$ のいう石灰化の完了した休止 期のセメント質にみられるものと同样と考えられる.

また透過電顕で観察すると，セメント質にコラーゲン 原線維束が封入して Sharpey 線維束となって終止して おり, Sharpey 線維束はコラーゲン原線維の周期構造 之同样の縞の周期構造が認められ，雨宮 $\left.(1983)^{26}\right)$ の報 告と同様の所見を呈している．町田（1960）101は成人の 霜牙を用いて，麻醉根管中間位切断を施した症例のう

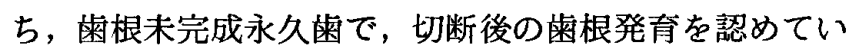
る.

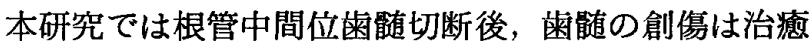
し， dentin barrier による被覆がなされ，㐘䯚内神経 線維の再生がおこり，霜根象牙質に部分的に内部吸収が あるものの，厚い雬根象牙質，根尖は有細胞セメント質 で閉鎖され，崡根膜の機能的配列がみられた。
結

幼若犬の根未完成永久䨑に根管中間位崡髄切断処置を

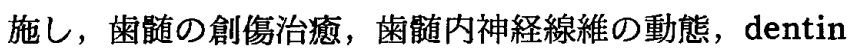
barrier の形成過程ならびに歯根の発育を含めて根尖閉 鎖について光顕的ならびに電顕的に検索し，以下の結果 を得た。

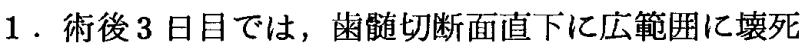
風の形成がみられ，壊死層直下の炎症首の神経線維は変 性に宿っていた。この部を透過電顕で観察すると，細胞 小器官に乏しい未分化間葉細胞がみられ，㖪鞘のミエリ ン部の破壊が著明な神経線維が認められた。根尖部には Hertwig上皮鞘が認められた。

2. 術後 1 週間目は, 切断面には石灰化柵形成開始所 見が認められ，直下の歯㖪には軽度の炎症性細胞浸潤が 限局していた。柵直下には，比較的核と細胞体の大型な 細胞を認め，透過電顕で観察すると，部分的に小さな陥 凹がある核をもち，細胞質内に粗面小胞体が豊富で，細 胞間隙の広い細胞が認められた。

3 ．術後 2 週間目になると，切断面直下には dentin barrier の形成開始所見がみられ，その部を走査電顕で 歯娟道側より観察すると, 大小の石灰化球样構造物が互い に痹合し重なりあって集合していた．ての部の細胞を透 過電顕で観察するとゆるやかな宿凹をもった大きな楕円 形の核と核の周囲をとり囲むように細胞質内に多数の 粗面小胞体とミトコンドリアで占められ，junctional complex で結合した象牙牙細胞様細胞を認めた，神経 線維を透過電顕で観察すると，䟼鞘は規則正しい層状構 造をもった正常な神経線維が認められた。

根尖部ではこの時期より有細胞セメント質の添加が みられ，透過電顕で観察すると対照群，実験群ともに active なセメント芽細胞が認められた。

4. 術後 1 力月から 2 力月経過例では, 切断面には辺 縁部から菌䯣中央部に連続して象牙細管構造をもった dentin barrier の形成が琹められた。乙の部を走查電 顕で観察すると曾冠側では管周象牙質が識別され，基質 との境界が明膫な所と不明瞭な所があり，象牙細管構造 は不均一であった，柵直下の細胞を透過電顕で観察する と，菌根象牙質の象牙芽紐胞と同様に，クロマチンに之 しい卵円形の大きな核と, 多数の粗面小胞体, ミトコン ドリアなど細胞小器官が偏在する所見が認められた。菌 㕼内神経線維は dentin barrier に向って小神経束及び 単一神経線維が上行していた. 根尖部は有細胞セメント 質の添加が活発に行われ，透過電顕で観察すると，大型 
の楕円形の核をもち豊富な粗面小胞体， ミトコンドリア が媤められた。

5 . 術後 6 力月目に至ると, dentin barrier は厚さ を増し, dentin barrier を走査電顕で観察すると歯髄 側では石灭化球が規則正しく分布し, 癒合し, 緻密さを 増し均一な象牙細管構造を有していた。神経線維はこの 時期に至ると, dentin barrier に達し, 柵に平行に辺 縁部の象牙牙細胞層に終止するものや，㐘髄の固有組織 や血管とともに，䒽内に進入している所見がみられた。

根尖部は一部わずかな象牙質の内部吸収がみられる が，その部にセメント細胞を封入したセメント質の形成 がみられ，石灭化は完了し，対照群とほぼ同程度の根尖 閉鎖が認められた。この部を走査電顕で観察すると，刘
照群，実験群とも平滑面を形成し，石灭化度の高いセメ ント小腔が認められた。 セメント質表面のセメント芽細 胞を透過電顕で観察すると, 粗面小胞体, ミトコンドリ アの乏しい resting cell の状態を呈していた。㐘根膜 線維束は機能的配列を示していた。

稿を終るにあたり，本研究に際して終始で飱篤なるで 指導とご校閲を賜わりました恩師木村光孝教授に深甚の 謝意を捧げます．また本実験に種々の御協力を戴いた小 児龱科学教室の各位に御礼申し上げます。

本論文の要旨は，昭和63年 5 月20日第26回日本小児歯 科学会大会において発表した。

\section{引用 文 献}

1) 木村光孝：根未完成歯の歯髄の処置に関する実験的研究. 九州歯会誌 $27: 17-44,1973$.

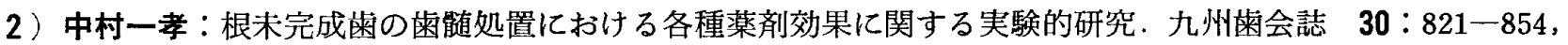
1977 .

3) 神内正人：Apexogenesis に伴う棶髄内神経線維の消長に関する実験的研究. 九州雨会誌 $39: 1$ - 26 , 1985.

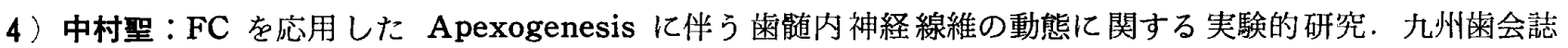
$41: 25-45,1987$.

5 ) 鬼塚一徳：Apexificationに伴う根尖閉鎖硬組織のX線学的ならびに電子顕微鏡的研究. 九州㐘会誌 40 ： $165-187,1986$.

6 ）長谷川 喬：Apexification に伴う雬根膜の創傷治癒に関する実験的研究. 九州米会誌 40:1一-30, 1986 .

7) Ungewitter, L.H. : A urea silver nitrate method for nerve fibers and nerve endings. Stain Tech. $26: 73-76,1951$.

8 ) Powers, M.M. : The staining of nerve fibers in teeth. J. Dent. Res. 31:383-392, 1952.

9）品川光春：歯根末完成歯の根尖閉鎖に関する実験的研究. 九州歯会誌 $34: 355-376,1980$.

10）町田幸雄：抜髄法並びに根管中間位粜髄切断法に関する臨床病理学的研究. 日蒾保誌 $3: 126-189,1960$.

11）山田 車：雨髄切断部位が，その後の治癒におよぼす影響。歯科医学 $33: 711-730,1970$.

12) Stanford, J.W. : Recommended standard practices for biological evaluation of dental materials. Int. Dent. J. $30: 140-188,1980$.

13) Stanley, H.R. : American national standards institute/American Dental Associatipn Document. No. 41 for biological evaluation of dental materials. J. Am. Dent. Assoc. $99: 697$ $-698,1979$.

14) Working Group 5 of the FDI Commission on Dental Products : Biological evaluation of dental materials. ISO Technical Report 7405, 1983.

15）東 富恵：生活茵髄切断法における硬組織此蓋形成過程に関する電子顕微鏡的研究 I. 脱灰標本による組 織の変化の検討. 広大歯誌 $13: 248-275,1981$.

16）市川徽：犬における生活歯䯣切断後の Dentin Bridge 形成に関する光顕的ならびに電顕的研究. 柬科学報 $76: 391-439,1976$.

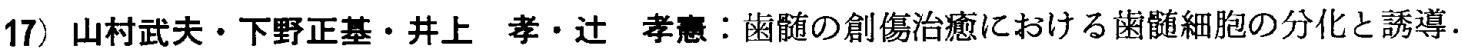
蔝基礎誌 $27: 395-408,1985$. 
18) Fitzgerald, M. : Cellular mechanics of dentinal bridge repair using ${ }^{3} \mathrm{H}$-thymidine. $J$. Dent. Res. $58: 2198,1979$.

19）大野秀夫：乳茵蒾䯙切断後の創傷治癒に関する実験的研究. 九州歯会誌 $40: 911-933,1986$.

20）中村富明：乳歯歯髄切断後の dentin barrier に関する実験的研究. 九州雪会誌 $40: 1065-1097 ， 1986$.

21）伊津進弘：象牙質被蓋形成機序に関する光学顕微鏡ならびに電子顕微鏡的研究. 歯科医学 $39: 583-622$, 1976.

22）松山道孝：乳歯歯髄切断後の創傷治痛に関する神経組織学的研究. 九州歯会誌 $38: 1042-1063,1984$.

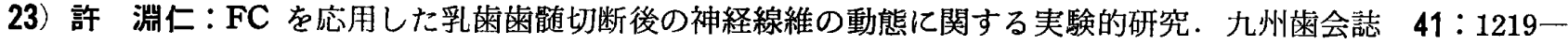
$1237,1987$.

24) Nathaniel, E.T.H. and Peace, D.C. : Degenerative changes in rat dorsal roots during Wallerian degeneration. J. Ultrastruct. Res. 9:533-549, 1963.

25）辻 裕文 : 根未完成永久雨再植後の根尖周囲組織の治癒過程に関する X線学的, 光顕的ならびに透過型電子 顕微鏡的研究. 九州歯会誌 $42: 1-29,1988$.

26）木村光孝：根未完成永久歯根尖部の組織変化. 歯科ジャーナル $27 ： 855-861 ， 1988$.

27）雨宮 晴：歯根膜，セメント質の微細形態と病変. 細胞 $15: 404-408 ， 1983$.

28) Armitage, G.C. : Cementum. In:Orban's Oral histology and embryology (ed. by Bhaskar, S.N.). 9ed., Mosby St. Louis, 1980, 180-203. 